\title{
TERACOTE DIN AȘEZAREA CIVILĂ ROMANĂ DE LA OSTROV (DUROSTORUM), JUDEȚUL CONSTANȚA (III)
}

\section{ADELA BÂLTÂC, CHRISTINA ȘTIRBULESCU}

\section{THE TERRACOTTAS OF THE ROMAN CIVIL SETTLEMENT AT OSTROV (DUROSTORUM), CONSTANȚA COUNTY (III)}

The present paper is the third one about an important group of material unearthed during the archaeological diggings of the Roman settlement at Ostrov (Durostorum), Constanța County, "Ferma 4" site. The first two papers presented 103 items discovered during the 1998-2007 campaigns. Subsequently the studying over 520 terracottas found during the 2008-2016 campaigns, could be achieved a better division of the terracottas on categories, as it follows: human statuettes, animal statuettes, constitutive elements of complexed objects and incerta. In the present study are displayed 79 items from the human statuettes category, comprising the individual statuettes and the statuary groups. In the current paper have been identified 14 pieces representing deities, 22 pieces representing private male statuettes, 18 female statuettes and 25 fragments representing parts of human statuettes ( 9 body fragments, 10 arms fragments and 6 feet fragments). Among the presented pieces, a specific debate concerns the Thracian Horseman (cat. no. 1). The clay representations of the local god are scarce, despite the thousands stone representations in the Thracian milieu. Also, are displayed new items representing Venus, a well-known deity to the coroplastic art of Ostrov. Is further individualized one female statuettes (cat. no. 35) who can be remarked through the fashion of garment and the hands position. Due to the support of the archaeological context, the items can be dated to the mid-second century - mid-third century AD.

KEYWORDS: archaeological diggings, terracottas, the Thracian Horseman, Venus, Roman era. CUVINTE CHEIE: cercetări arheologice, teracote, Eroul Cavaler, Venus, epoca romană.

\section{INTRODUCERE}

Studiul de față este cel de-al treilea ${ }^{1}$ dedicat unei categorii importante de material rezultat în urma cercetărilor arheologice sistematice asupra așezării romane de la Ostrov (Durostorum), jud. Constanța, punctul Ferma 4. Primele două articole au prezentat piesele descoperite în campaniile 1998-2007 și au încercat, pe cât posibil, o catalogare a celor 103 piese, acestea fiind împărțite în două grupe majore ${ }^{2}$ - teracote destinate statuariei minore și teracote folosite la decorarea pieselor ceramice. Cercetările desfăşurate în perioada 2008-2016 au condus la descoperirea unui număr impresionant de teracote, chiar dacă fragmentare, ceea ce ne-a permis abordarea sub o altă formă a modului de publicare a acestora ${ }^{3}$. Datorită numărului mare de piese studiate (cca 520) s-a putut realiza o mai eficientă clasificare a teracotelor, față de primul studiu ${ }^{4}$, după cum urmează: statuete umane, statuete reprezentând animale și elemente constitutive ale unor obiecte complexe. Din cauza fragmentarității, o serie de piese nu au putut fi catalogate, urmând să fie introduse în categoria incerta.

În prima categorie, statuete umane, se constată două tipuri, statuete individuale şi grupurile statuare. Pentru studiul de față am selectat 79 de piese care se încadrează în categoria statuetelor umane, cuprinzând atât statuete individuale, cât și grupuri statuare. Din această din urmă categorie a fost selectată doar perechea zeilor Venus-Eros, deoarece aceștia sunt redați și împreună și separat, în arta coroplastică de la Ostrov, urmând ca grupul divinităților pereche, foarte bine reprezentat în plastica durostoreană, să fie abordat într-un studiu viitor.

\footnotetext{
${ }^{1}$ Bâltâc, Știrbulescu 2007-2008; Bâltâc, Știrbulescu 2010.

${ }^{2}$ Bâltâc, Știrbulescu 2007-2008, 168.

${ }^{3}$ Primul studiu a fost dedicat statuariei minore, iar cel de-al doilea a completat această categorie cu câteva piese, dar a cuprins și piesele descoperite în campaniile din perioada 1998-2007, care se încadrează în cea de-a doua categorie stabilită.

${ }^{4}$ Bâltâc, Știrbulescu 2007-2008, 169.
} 


\section{CARACTERISTICILE PIESELOR}

Teracotele au fost descoperite pe toată suprafața cercetată în perioada 2008-2016 , unele provenind din gropile identificate la est și nord de edificiul termal, altele din complexe anterioare construirii edificiului nr. $3^{6}$, ceea ce oferă elemente pentru datarea unora dintre obiecte.

Piesele sunt confecționate din pastă fină, în cele mai multe cazuri arsă oxidant, chiar dacă uneori (14 cazuri) neuniformă, 8,97\% fiind arse reducător, ceea ce păstrează caracteristicile sesizate anterior. Pasta este, în general, bine omogenizată, rar se întâlnesc granule de calcar sau ceramică pisată. Doar în două cazuri pasta este caolinoasă, ceea ce ridică numărul teracotelor confecționate din această pastă la doar cinci ${ }^{7}$, în așezarea de aici. La o singură piesă (nr. cat. 29) se constată arderea până la vitrifiere, fenomen întâlnit la alte patru piese deja publicate ${ }^{8}$. Doar la opt piese s-au constatat urme de vopsea sau firnis (nr. cat. 1și 2, 12, 17, 22, 44 și 45, 73) și doar o piesă (nr. cat. 30) păstrează în proporție de $90 \%$ firnisul care o acoperă.

Cea mai mare parte a pieselor (70) sunt modelate în tipar, fiind sesizate retușuri în pasta crudă la exterior (cu un obiect ascuțit pentru îndepărtarea surplusului), iar la interior se observă surplus de material la unirea dintre valve sau urme de amprente digitale. În nouă cazuri (nr. cat. 65-71, 73 și 74) se observă modelarea cu mâna a pieselor, fiind vorba despre mâini și picioare de la statuete. În cazul multor statuete, mai ales la cele la care se păstrează fața, se constată că trăsăturile sunt foarte șterse, ceea ce indică o folosire îndelungată a tiparelor.

Cele 79 de piese selectate, pentru studiul de faţă, reprezintă statuete umane, păstrate fragmentar, și se pot diviza în statuete care înfățișează divinități, personaje masculine, personaje feminine, precum și fragmente ale unor statuete umane.

\section{DIVINITĂȚI}

Dintre piesele studiate, în cazul a 14 au fost identificate elemente certe care indică faptul că teracotele înfățișează divinități, și anume: Eroul Cavaler, Dionysos, Venus și Eros.

Eroul Cavaler este reprezentat pe o placă de formă dreptunghiulară (nr. cat. 1), din care se păstrează doar un mic fragment din călăreț și cal, respectiv picioarele. Deși cultul acestui personaj este foarte răspândit în mediul tracic și de influență tracică ${ }^{9}$, fiind foarte bine reliefat în variate monumente din piatră, reprezentările în lut sunt extrem de rare, ele reducându-se, din investigațiile noastre, la 11 piese $^{10}$, dintre care doar șase ${ }^{11}$ sunt publicate până în prezent ${ }^{12}$. Pentru trei dintre piese (Histria ${ }^{13}$ și Capidava $^{14}$ ) se poate postula o datare în epoca elenistică, ceea ce reduce piesele din epoca romană la trei, respectiv la cele de la Heraclea Sintica (Rupite, oblast Blagoevgrad, Bulgaria). Acestea din urmă sunt tot plăci de formă dreptunghiulară, care păstrează numeroase elemente cunoscute în reprezentările

\footnotetext{
5 Despre cercetările arheologice din punctul Ferma 4, vezi CCA 2017, 103-104, nr. 55, nota 73.

${ }^{6}$ CCA 2015, 109, nota 85.

7 Bâltâc, Știrbulescu 2007-2008, nr. cat. 30; Bâltâc, Știrbulescu 2010, nr. cat. 13, 23.

8 Bâltâc, Știrbulescu 2007-2008, nr. cat. 39, 40,69.

9 CCET I, CCET II/1, CCET II/2, CCET IV.

${ }^{10}$ Este vorba despre piese de la Capidava (una), Madara (una), Plovdiv (una), Histria (cinci) și Heraclea Sintica (trei).

${ }^{11}$ Capidava (Scorpan 1967, nr. 22), Histria (Coja 1974, 283), Heraclea Sintica (Milčev 1959, 69, fig. 50; Cholakov 2008, 72-73, nr. 42 si 43).

12 Piesele de la Madara și Plovdiv sunt inedite. Mulțumim domnului dr. Ivo Cholakov pentru informațiile privind piesele din Bulgaria. În cercetările recente din sectorul Poarta Mare - Turnul Mare de la Histria, au fost descoperite şi trei teracote cu reprezentarea Eroului. Mulțumim dl. dr. Paul Damian, responsabilul științific al sectorului, pentru că ne-a permis folosirea acestei informații.

${ }^{13}$ Una dintre teracote provine din cercetări arheologice anterioare celui de-al doilea război mondial, contextul arheologic este foarte neclar (Coja 1974, 284: „De toute façon, il est plus que probable, vu les superficies fouillées jusqu'à la veille de la deuxième guerre mondiale, qu'il provienne de la zone fortifiée de la cité hellénistique"), iar cea de-a doua este descoperită într-un context arheologic databil în epoca elenistică (Coja 1974, 284). Ambele piese sunt datate de autoare în secolul al III-lea - prima parte a secolului al II-lea a. Chr.

14 Piesa este publicată ca provenind de la Capidava „descoperire întâmplătoare” (Scorpan 1967, 50), însă în registrul inventar al Muzeului de Istorie Națională și Arheologie din Constanța este menționată localitatea Techirghiol (mulțumim domnului Dan Vasilescu, MINAC, pentru amabilitatea de a verifica informațiile în registrul inventar). Detaliile stilistice ale piesei, mai ales coafura călărețului, indică similitudini cu piesele de la Histria, ceea ne determină să ne îndoim atât în ceea ce privește locul de descoperire (Capidava), cât și asupra datării oferite de autor (sec. II-III p. Chr.).
} 
din piatră ale Eroului și sunt produse în atelierul de la Heraclea Sintica, care funcționează de la mijlocul secolului al III-lea până la sfârșitul secolul al III-lea p. Chr ${ }^{15}$. Piesa de la Ostrov este fragmentară și păstrează foarte puține elemente astfel încât este dificil de încadrat în vreuna dintre tipologiile propuse pentru reprezentările Eroului Cavaler ${ }^{16}$, însă este foarte diferită de reprezentările de la Heracleea Sintica. Astfel, considerăm că piesa este un produs local al atelierelor de la Durostorum, iar pe baza contextului arheologic al descoperirii ${ }^{17}$, propunem o datare în secolul al II-lea - mijlocul secolului al III-lea p. Chr.

Zeul Dionysos este reprezentat pe o aplică (nr. cat. 2) care se adaugă celorlalte trei aplice dionisiace deja cunoscute din așezare ${ }^{18}$ însă, spre deosebire de celelalte, pe suprafața celei de față se regăsesc elemente care să-l identifice sigur pe zeu. Ca și celelalte piese de acest gen de la Ostrov, și aceasta este o aplică pentru vas. Numărul mare de astfel de aplice indică faptul că acest cult este foarte răspândit în zona anticului Durostorum, fără îndoială strâns legat de cultivarea viței-de-vie. Maniera de redare a bărbii și contextul arheologic al descoperirii pledează pentru o datare în epoca antoniniană.

Zeului Eros i se adaugă trei noi reprezentări (nr. cat. 3-5) celor trei deja cunoscute anterior din așezare $^{19}$. Și acum avem de-a face cu două tipuri de redări: cel de copil aflat la o vârstă fragedă - putto (nr. cat. 4) și cel de copil/adolescent (nr. cat. 3, 5), reprezentat alături de mama sa. Probabil și datorită acestei asocieri, reprezentările lui Eros sunt printre cele mai des întâlnite în statuaria de la Ostrov.

Se poate constata că zeiţa Venus este cea mai populară divinitate în coroplastica de la Ostrov. Piesele provenite din atelierele de aici sunt numeroase ${ }^{20}$, iar noile descoperiri din așezare vin să confirme aceste date. Nouă astfel de reprezentări se adaugă celor opt deja cunoscute ${ }^{21}$. Din fericire, una dintre piese (nr. cat. 5) este aproape întreagă și ne poate oferi indicii pentru celelalte fragmente. Piesa reprezintă grupul statuar Venus-Eros copil, redat pe un soclu decorat cu un căluț de mare ${ }^{22}$ stilizat. Astfel, se dovedesc corecte identificările noastre precedente ale unor fragmente cu acest grup statuar. Ne referim la un soclu decorat cu hippocampus ${ }^{23}$, la un fragment pe care este reprezentat cuplul Venus - Eros $^{24}$, publicate anterior, la care se adaugă sigur nr. cat. 3 din prezentul catalog, eventual și piesele de la nr. cat. 7-9. Dintre multiplele valențe pe care zeița Venus ajunge să le reprezinte, asocierea cu Eros, face sigur trimitere spre latura amoroasă, fiind strâns legată de iubire, căsnicie și fertilitate.

Celelalte piese care o reprezintă pe Venus (atât cele din prezentul catalog, cât și cele publicate anterior) din cauza fragmentaritătii lor, nu pot fi introduse în vreuna dintre categoriile tipologice cunoscute $^{25}$. Excepție face piesa nr. cat. 8 care păstrează detalii care o pot încadra cert în tipul Venus pudica. De asemenea, este posibil ca această piesă să fi avut valva posterioară asemănătoare piesei nr. cat. 13, deoarece ambele au o siluetă mai îngustă; cele două fragmente nu au elemente de legătură, chiar dacă din punct de vedere anatomic se potrivesc, dar este posibil ca valvele folosite să fie de la același ansamblu. Frecvența reprezentărilor zeiței Venus în această zonă poate fi legată, evident, și de mediul militar, însă suntem de părere că avea un rol important și în practicarea cultului imperial, dat fiind faptul că zeița este frecvent asociată acestor manifestări.

\footnotetext{
${ }^{15}$ Cholakov 2008, 55.

16 Tipul A: Cavalerul la dreapta, la pas sau în repaus. Tipul B: Cavalerul la dreapta, cele mai multe reprezentări îl redau în galop, cu lance în mână. Tipul C: Cavalerul în galop, cu prada de la vânătoare în mâini, întorcându-se de la vânătoare. În general, tipologia propusă în CCET I (p. X-XI), este unanim acceptată și folosită de exegeți, chiar dacă uneori suferă minore modificări ale descrierilor din fiecare tip în parte.

17 Piesa provine dintr-un complex arheologic anterior construirii edificiului nr. 3, datat la sfârşitul secolului al III-leaînceputul secolului al IV-lea p. Chr.

${ }^{18}$ Bâltâc, Știrbulescu 2010, nr. cat. 10-12.

${ }^{19}$ Bâltâc, Știrbulescu 2007-2008, nr. cat. 5, 11, 60.

${ }^{20}$ Mușețeanu, Elefterescu 1985, 187-190.

${ }^{21}$ Bâltâc, Știrbulescu 2007-2008, nr. cat. 1-5, 11, 60; Bâltâc, Știrbulescu 2010, nr. cat. 2.

${ }^{22}$ Pentru redarea lui hippocampus în reprezentările asociate zeiței Venus, vezi LIMC VIII/1, 218, nr. 301, tipul XIV.

${ }^{23}$ Bâltâc, Știrbulescu 2007-2008, nr. cat. 60. Din cauza reprezentării foarte schematice am identificat animalul ca fiind un delfin, având în vedere exemplarul de față considerăm că și pe suprafața soclului publicat anterior trebuie identificat hippocampus.

${ }^{24}$ Bâltâc, Știrbulescu 2007-2008, nr. cat. 11.

${ }^{25}$ LIMC VIII/1, 195-227.
} 


\section{STATUETE MASCULINE}

Un număr de 21 de piese (nr. cat. 14-34), datorită detaliilor păstrate pe fragmente, au fost catalogate ca aparținând unor statuete masculine. Detaliile reliefate pe două piese par a reprezenta tineri, un cap cu trăsături adolescentine (nr. cat. 14) și un fragment din torsul unui personaj, reprezentat nud sau seminud (nr. cat. 15), ale cărui detalii anatomice par a reda un corp de tânăr. Nu este exclus ca acest fragment să aparțină unei statuete care-1 reprezintă pe Eros adolescent. Detaliile păstrate pe trei fragmente (nr. cat. 16-18), indică faptul că acestea provin de la teracote reprezentând busturi umane pe soclu (de formă circulară). Astfel de imagini sunt des reprezentate în piatră, însă cel mai adesea redau împărați sau personalități. Piesele de față, păstrează pe valvele anterioare detaliile mantiilor cu care sunt înveșmântate personajele, la una dintre acestea fiind redată și o fibulă circulară cu care este prinsă pe umăr. Suntem de părere că aceste teracote reprezintă personaje particulare, cel mai probabil de pus în legătură cu cultul strămoșilor. În lumea romană, cultul strămoșilor este strâns legat de cultul privat, care se oficia în fiecare cămin, imaginile strămoșilor defuncți, transformați în eroi/zei, fiind venerați ca atare ${ }^{26}$.

Şapte fragmente reprezintă personaje înveșmântate (nr. cat. 19-25), însă nu se pot distinge caracteristici unitare care să permită o eventuală catalogare a acestora, fiecare piesă individualizânduse. Dintre acestea, două piese par a reda elemente care amintesc de veșmintele militare, nr. cat. 20 (prin impresiunile de pe corp, dar mai ales prin redarea centurii) și nr. cat. 21 (prin modalitatea de redare a veșmântului pe umăr și sugerarea centurii). Interesantă este piesa nr. cat. 19, care prezintă un orificiu pentru aplicarea unui obiect din piatră sau metal, ceea ce ar putea aduce în discuție o posibilă reprezentare a unei divinități, decât a unei persoane particulare. Piesa nr. cat. 22 ar putea proveni de la un bust pe soclu, însă este dificil de catalogat în lipsa unor elemente certe.

Doar pentru piesele nr. cat. 23-26 se constată o caracteristică comună, şi anume redarea brațelor îndoite, aproximativ într-un unghi drept, spre piept, însă fiecare statuetă are elementele de veșminte individualizate. În lipsa unor analogii certe este dificil de stabilit ce anume reprezintă această caracteristică.

Alte șase piese (nr. cat. 27-31) par a reprezenta personaje masculine, însă la acestea nu se disting elemente de veșminte, dar au o caracteristică comună, mâinile sunt redate îndoite și îndreptate spre gât. Piesele se caracterizează prin redarea schematică a mâinilor, iar trupul este redat compact, fără detalii anatomice. Alte două piese de la Ostrov publicate anterior ${ }^{27}$, aveau aceleași caracteristici, iar analogiile cele mai apropiate se regăsesc la o teracotă de la Butovo ${ }^{28}$, unde piesa este considerată a reprezenta un războinic, chiar dacă nu are elemente tipice militare (arme, elemente de echipament etc.). Analogia se reduce doar la maniera de redare a mâinilor, astfel încât nu avem alte argumente pentru a considera că piesele de la Ostrov reprezintă războinici. Modul de redare a mâinilor ar indica mai degrabă o atitudine pioasă, de rugăciune, astfel încât înclinăm să credem că poate fi vorba mai degrabă despre niște oranți.

Ultimele trei piese din această categorie (nr. cat. 32-34) reprezentând statuete masculine și nu prezintă caracteristici particulare care să facă posibilă detalierea lor.

\section{STATUETE FEMININE}

Statuetele feminine sunt reprezentate prin 18 piese (nr. cat. 35-52) și, cu o singură excepție (nr. cat. 35), este vorba despre capete. Au fost constatate caracteristici care ne-au permis împărțirea în trei subgrupe: personaje cu văl, personaje cu „turban” pe cap și personaje cu capul descoperit.

Pentru șase statuete (nr. cat. 36-41) se constată că au părul acoperit cu un văl, coafurile sunt diferite, la fel și modalitatea de redare a vălului, ceea ce indică faptul că avem de-a face cu tipare diferite. Doar într-un singur caz piesa este completată de un decor. La două statuete (nr. cat. 42-43) se constată că părul este ascuns sub un acoperământ de formă conică, redat prin muluri paralele, asemănătoare unui „turban”. Astfel de acoperăminte sunt întâlnite pe reprezentările monumentelor din

\footnotetext{
${ }^{26}$ DA III/2, p. 937; DA IV/1, p. 376. LIMC, VI?1, s.v. Lar, Lares, 205.

${ }^{27}$ Bâltâc, Știrbulescu 2007-2008, nr. cat. 39-40, unde opinam că piesele pot reprezenta statuete de copii.

${ }^{28}$ Sultov 1976, 92.
} 
piatră $^{29}$. Nouă piese (nr. cat. 44-52) sunt figurate cu capul descoperit, fie că este vorba de valva anterioară, fie de cea posterioară, pe majoritatea este redată coafura sau doar buclele. Acestea sunt figurate fie prin incizii paralele, oblice sau vălurite, fie prin impresiuni. Toate exemplarele de statuete feminine indică folosirea unor tipare diferite, iar pe baza datelor oferite de fragmentele păstrate nu se poate preciza de la ce anume provin fragmentele (statuete de divinități sau persoane particulare).

Piesa nr. cat. 35 este aproape întreagă (lipsă doar capul) și se evidențiază nu doar prin maniera de redare a veșmântului (incizii oblice, paralele etc.), ci și prin poziționarea mâinilor, una pe abdomen și alta îndoită și îndreptată spre gât. Cea mai apropiată analogie o întâlnim la Barboși (jud. Galați), unde editorul o datează în a doua jumătate a secolului al II-lea - prima jumătate a secolului al III-lea p. Chr. și identifică personajul cu zeița Demetra. În lipsa unor atribute specifice, este dificil de asociat statueta de aici cu zeița în cauză. Maniera de redare a veșmântului, foarte schematică și simplă, amintește de reprezentările de pe monumentele din piatră și pare specifică mai degrabă unei persoane particulare $^{30}$, posibil tot într-o poziție de penitență sau adorare. Contextul arheologic al piesei de la Ostrov permite o datare asemănătoare cu cea de la Barboși, eventual până la mijlocul secolului al IIIlea p. Chr.

\section{STATUETE UMANE (VARIA)}

Un număr mare de fragmente (25) reprezintă părți din statuete umane: nouă fragmente din corp, 10 fragmente din brațe și șase din picioare, și care, din cauza fragmentarității, nu pot fi încadrate unei categorii stabilite anterior. În primul studiu dedicat teracotelor de la Ostrov ${ }^{31}$, detaliile anatomice și alte caracteristici păstrate pe fragmentele în cauză, ne-au permis catalogarea acestora printre statuetele feminine sau masculine. Pentru fragmentele de față, este dificil de făcut această împărțire, pentru moment.

Dintre fragmentele de corp, trei (nr. cat. 53-55) reprezintă torsuri înveșmântate și șase (nr. cat. 56-61) posibile nuduri, doar pentru nr. cat. 56-59 se poate presupune că ar putea proveni din statuete care o reprezintă pe zeița Venus. Dintre cele 10 fragmente de brațe (nr. cat. 62-72), doar șapte păstrează palma și cu excepția unei singure piese (nr. cat. 62) se constată ca acestea nu au redate degetele cu excepția lui pollex, care în toate cele șase cazuri este redat cu vârful retezat. Acest detaliu poate indica faptul că în palma statuetelor era aplicat un accesoriu, fapt întărit și de modalitatea de redare a brațului - îndoit. Într-un singur caz (nr. cat. 68) obiectul este și păstrat (o bucată de lut de formă semicirculară), însă este dificil de specificat ce reprezintă. Un singur fragment (nr. cat. 72) reprezintă un braț detaşabil dintr-un ansamblu, având un orificiu de prindere în zona umărului. Detaşabil este și un picior (nr. cat. 78) păstrat aproape întreg, însă nu putem afirma dacă ele aparțin aceleiaşi statuete.

Celelalte cinci fragmente de picioare (nr. cat. 73-78) păstrează suprafața plantară, uneori și o porțiune din gambă. În patru cazuri personajele sunt redate desculțe (nr. cat. 73-76), fiind reprezentate degetele, şi ar putea proveni de la statuete masculine sau reprezentând copii. Doar într-un singur caz (nr. cat. 77) se disting elemente certe ale unei încălțăminte înalte, redată doar în partea de sus, prin trei muluri. Tot la această statuetă, pe gamba din spate, se păstrează un fragment, care poate proveni de la un accesoriu, dar nu putem să nu ne gândim și la o posibilă redare a unei aripioare, ceea ce ar face posibilă identificarea cu un atribut al zeului Mercurius.

\section{DATARE}

Așa cum am mai menționat, piesele provin din toată așezarea, fie din pământul adus pentru nivelare în vederea construirii edificiului nr. 3, fie din complexe (gropi) de sub același edificiu, ceea ce ne îndreptățește să propunem intervalul dintre mijlocul secolul al II-lea - mijlocul al III-lea pentru datarea pieselor din prezentul catalog.

\footnotetext{
${ }^{29}$ Bâltâc et alii 2015, 200, nr. 203.

${ }^{30}$ Ţeposu-Marinescu 1982, 221-222, nr. AE 107, pl. 41; Man 2011, 222, nr. 1, pl. 161/1 (registrul inferior); Bâltâc et alii 2015, 162-163, nr. 157 (registrul inferior)

${ }^{31}$ Bâltâc, Știrbulescu 2007-2008.
} 


\section{CATALOG $^{31}$}

1. PLACĂ (fragmentară). PI. I/1. Dr. 2009/43, C18 (profil vestic), $-1,49 \mathrm{~m}$. Pastă fină (arsă oxidant), de culoare $^{32}$ Munsell 7.5YR8/4, cu particule de mică, oxizi rari, particule calcar dese. Urme de firnis pe piciorul personajului. Modelare în tipar (mici incizii cu un obiect ascuțit în pasta crudă pe față; surplus de material pe față și spate; urme de amprente digitale pe spate). Lut ars. $\mathrm{Lp}=7,35 \mathrm{~cm}$, $\mathrm{lp}=4,68 \mathrm{~cm}, \mathrm{Gr}=0,91 \mathrm{~cm}$. Se păstrează partea inferioară a unei plăci, de formă dreptunghiulară, cu reprezentarea Eroului Cavaler, în galop spre stânga. Se observă o parte din pieptul, umărul și antebrațul calului, precum și piciorul călărețului. $\mathrm{Nu}$ sunt redate detalii ale vreunei încălțări. Nr. inv. pr. 104. Analogii: Heraclea Sintica, plăci (din lut): Milčev 1959, p. 69, fig. 50; Cholakov 2008, p. 72-73, nr. 42-43.

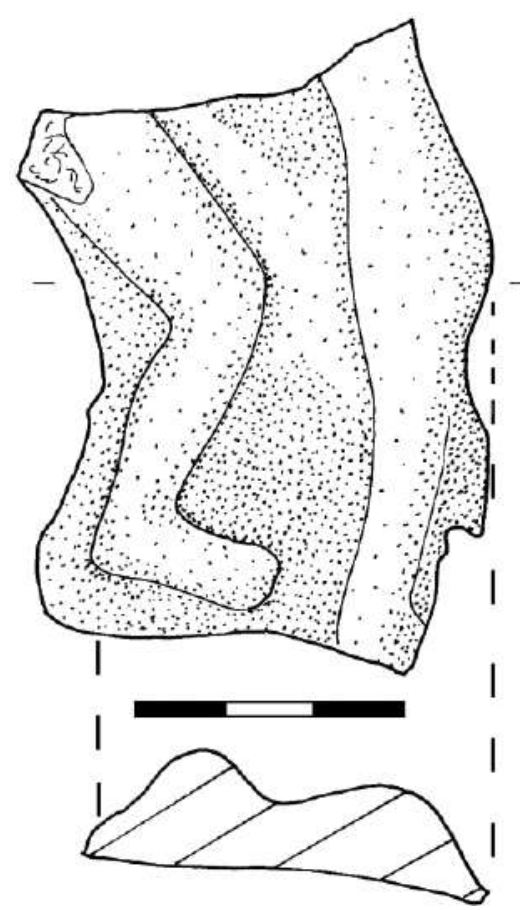

2. APLICĂ (fragmentară). PI. I/2. Se păstrează un fragment din valvă (monovalv). Dr. 2016/364, C22, caroul 6. Pastă fină (arsă oxidant) de culoare Munsell 2.5YR7/8, cu particule de mică, oxizi relativ rari, particule calcar rare. Urme de vopsea de culoare Munsell 10R6/8 la exterior. Modelare în tipar. Lut ars. $\mathrm{Lp}=8,73, \mathrm{~cm}, \mathrm{lp}=5,45 \mathrm{~cm}, \mathrm{Gr}=$ $1,74 \mathrm{~cm}$. Se păstrează capul zeului Dionysos. Trăsăturile zeului sunt cele ale unui bărbat matur. Ochii bine conturați, au pupila marcată. Nasul ușor proeminent. Gura are buzele uşor întredeschise. Coafura și barba bogată acoperă cea mai mare parte a feței. Mustața face corp comun cu restul bărbii (despărțită în două părți pe mijlocul bărbiei), şuvițele au aspectul unor mici spirale. Pe frunte are

\footnotetext{
${ }^{31}$ Abrevierile folosite în prezentul catalog sunt: $\mathrm{C}=$ casetă, Dr. = Durostorum, $\mathrm{L}=$ lungime, 1 = lățime, $\mathrm{Gr}=$ grosime, $\mathrm{p}=$ păstrată ${ }^{32}$ Pentru redarea culorii s-a folosit catalogul Munsell 2013.
}

o panglică, redată prin două benzi. Pe creștetul capului pare a fi redat un bucraniu din care pornesc vrejuri și frunze de viță-de-vie care cad în părțile laterale, amestecându-se cu buclele de păr. Nr. inv. pr. 105.

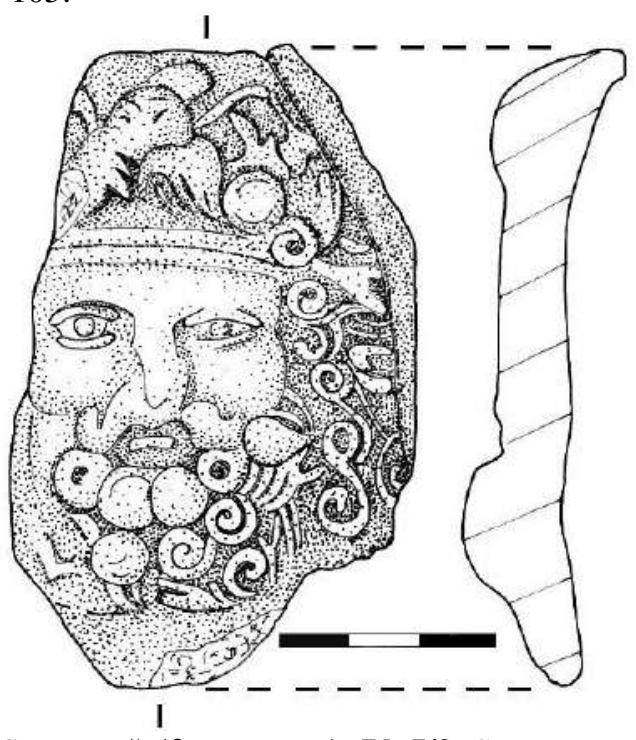

3. STAtUetă (fragmentară). PI. I/3. Se păstrează un fragment din valva anterioară. Dr. 2012/76, C21, caroul 14d, $-1,67$ m. Pastă semifină (arsă oxidant) de culoare Munsell 5YR7/8 cu particule de mică, oxizi deși, uneori sub formă de granule cu dimensiuni până la $4 \mathrm{~mm}$ și pietricele cu dimensiuni până la 4 $\mathrm{mm}$. Modelare în tipar, cu surplus de material pe interior (mici incizii cu un obiect ascutitit în pasta crudă pe față). Lut ars. $L p=6,20 \mathrm{~cm}, 1=3,50 \mathrm{~cm}, \mathrm{Gr}$ $=0,75 \mathrm{~cm}$. Se păstrează o parte din jumătatea superioară a unei statuete reprezentându-1 pe zeul Eros. Părul buclat cade pe ambele părți ale tâmplei. Capul spart în partea superioară. Trăsăturile feței foarte șterse, brațele adunate la nivelul bazinului și împreunate. Se păstrează un fragment din aripă pe umărul drept. Ombilicul marcat. Cel mai probabil piesa făcea parte dintr-un grup statuar împreună cu zeița Venus. Nr. inv. pr. 106. Analogii: Ostrov, grup statuar (din lut): Bâltâc, Știrbulescu 2007-2008, 174, nr. 11, pl. 5/11; nr. 5 (din prezentul catalog).

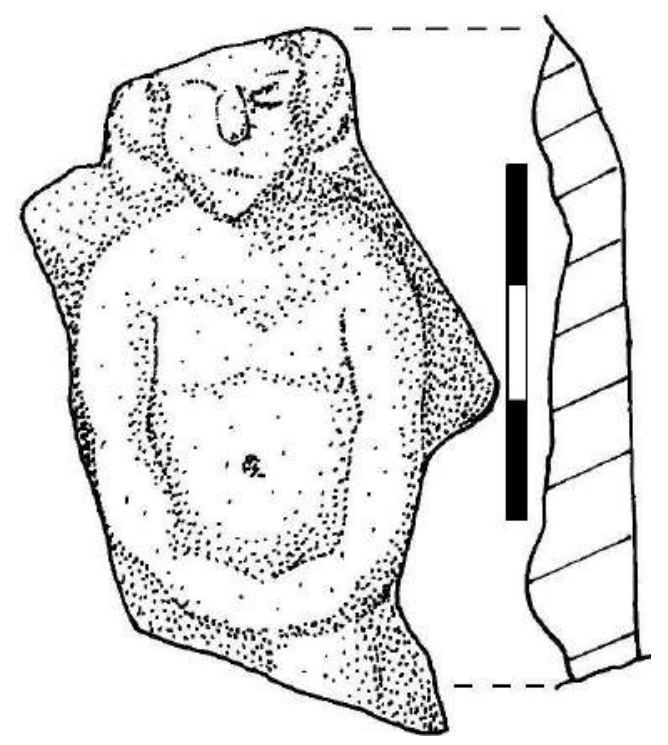


4. STATUETĂ (fragmentară). Pl. I/4. Se păstrează un fragment din valva anterioară și o mică porțiune din cea anterioară. Dr. 2008/381, C18, carouri 2a-d, 1,35-1,40 m. Pastă fină (arsă oxidant, dar neuniform) de culoare Munsell 2.5YR6/8, cu particule de mică, oxizi rari, particule calcar rare. Modelare în tipar. Lut ars. $\mathrm{Lp}=3 \mathrm{~cm}, \mathrm{lp}=3,09 \mathrm{~cm}$, $\mathrm{Gr}=0,37 \mathrm{~cm}$. Un fragment din capul unui personaj masculin (Eros), se păstrează doar ochiul drept redat alungit și pupila marcată. Coafura este redată prin incizii radiale, o parte fiind ruptă din vechime. Nr. inv. pr. 107. Analogii: Ostrov, statuetă (din lut): Bâltâc, Știrbulescu 2007-2008, nr. 5, pl. 3/5.

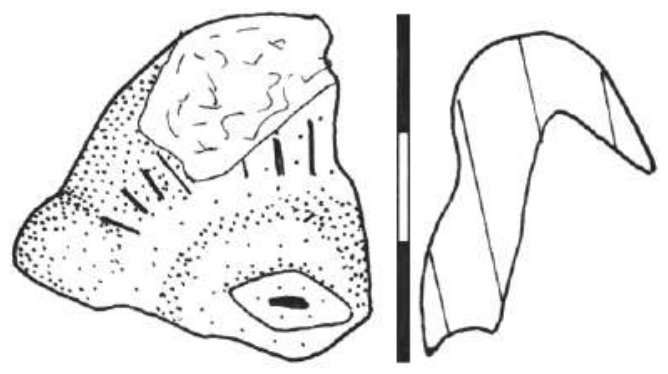

5. GRUP STATUAR (aproape întreg). Pl. II (infra p. 176). Se păstrează ambele valve. Dr. 2014/66, C18, caroul 1d, $-2,15$ m. Pastă fină (arsă reducător), de culoare Munsell 5YR7/6, cu particule de mică, oxizi, particule de calcar (uneori sub formă de granule de până la 3-4 mm; mici fisuri în pastă, depuneri calcaroase pe toată suprafața). Modelare în tipar (mici incizii cu un obiect ascuțit în pasta cruda pe față; mici incizii secundare). Lut ars. Lp = $18,64 \mathrm{~cm}, 1$ max. $=8,75 \mathrm{~cm}, \mathrm{Gr}=8,80 \mathrm{~cm}$. Se păstrează cca $90 \%$ din teracotă, lipsă capul zeiței Venus și o parte a brațului stâng. Grupul statuar o reprezintă pe Venus și Eros pe un soclu. Soclul este

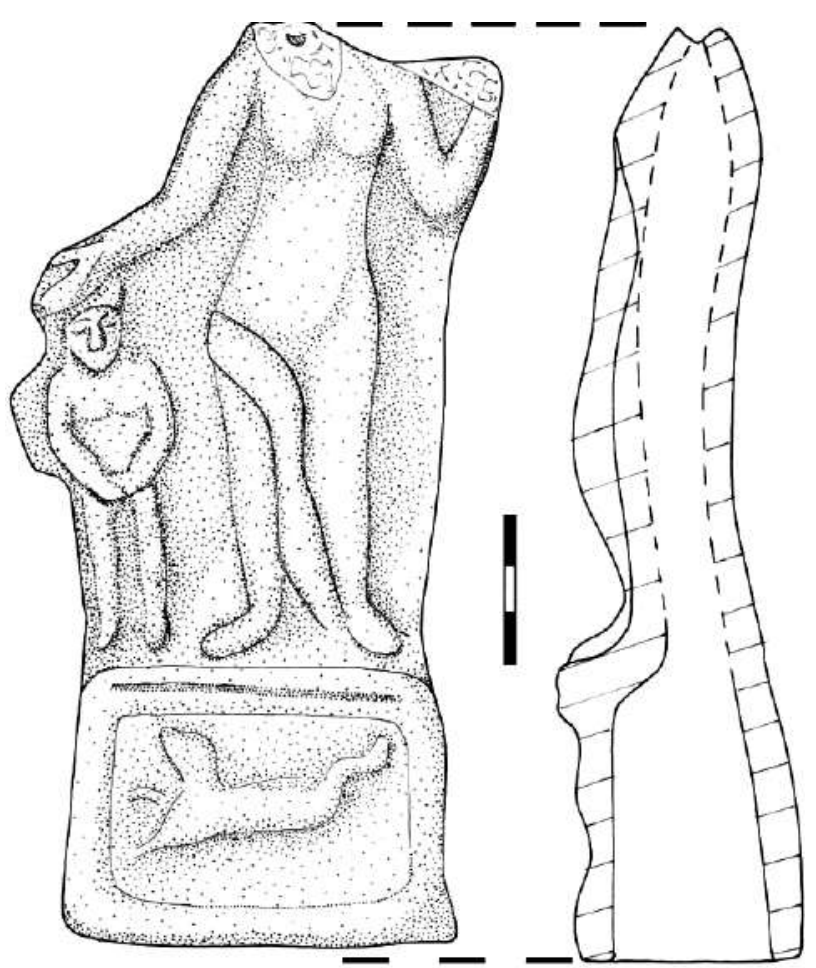

de formă paralelipipedic cu colțuri rotunjite, pe partea frontală este decorat un hippocampus, schematizat și cu trăsăturile foarte șterse. Decorul este delimitat de un chenar, mai pronunțat în partea de sus. Zeița, seminudă, stă în picioare, are piciorul stâng ușor flexat și dezgolit, piciorul drept probabil acoperit de veșmânt, care cade într-un fald de sub pubis până la călcâi, acoperind zona dintre picioare. Brațul drept este așezat pe capul lui Eros. Brațul stâng era ridicat în sus, probabil orientat spre cap. În partea dreaptă a zeiței se află redat zeul Eros în ipostaza de copil. Trăsăturile feței slab conturate. Mâinile lui sunt împreunate la nivelul bazinului și țin un obiect, neidentificat. Este redată doar aripa dreaptă a zeului. Pe spate nu sunt redate detalii anatomice. Nr. inv. pr. 108. Analogii: Ostrov, grup statuar (din lut): Bâltâc, Știrbulescu 2007-2008, nr. 60, pl. 14/60.

6. STATUETĂ (fragmentară). Pl. I/6. Se păstrează un fragment din valva anterioară. Dr. 2008/123, C18, caroul 1a, $-0,99$ m. Pastă fină (arsă oxidant), de culoare Munsell 7.5YR8/6, cu particule de mică, oxizi, rare particule de calcar; mici fisuri în pastă, depuneri calcaroase pe toată suprafața. Modelare în tipar, pe spate urme de la prelucrarea cu un obiect. Lut ars. $\mathrm{Lp}=7,70 \mathrm{~cm}, 1=4,60 \mathrm{~cm}, \mathrm{Gr}=0,6 \mathrm{~cm}$. Se păstrează o parte din jumătatea inferioară a unei statuete reprezentând-o pe zeița Venus. Piciorul stâng uşor flexat și dezgolit, piciorul drept acoperit de veșmânt, realizat din muluri oblice, paralele, faldurile formând o buclă sub pubis. În partea stângă este redată cealaltă parte a mantiei prin muluri verticale. Nr. inv. pr. 109.

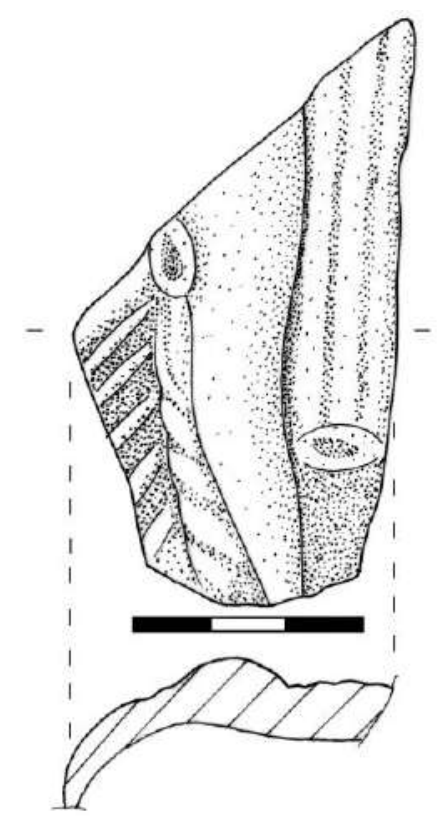


7. StAtuetă (fragmentară). PI. I/7. Se păstrează un fragment din valva anterioară. Dr. 2012/102, C21, caroul $17 \mathrm{c},-1,83 \mathrm{~m}$. Pastă fină (arsă oxidant) de culoare Munsell 5YR7/6 cu particule de mică, oxizi și particule milimetrice de fragmente ceramice; pietricele cu dimensiuni de până la $5 \mathrm{~mm}$. Modelare în tipar. Lut ars. $\mathrm{Lp}=5,20 \mathrm{~cm}, 1=4,15 \mathrm{~cm}, \mathrm{Gr}=$ $1,25 \mathrm{~cm}$. Se păstrează o parte din jumătatea inferioară a unei statuete reprezentând-o pe zeița Venus. Piciorul stâng este uşor flexat și dezgolit, piciorul drept acoperit de veșmânt, care este redat căzând în falduri. Nr. inv. pr. 110.

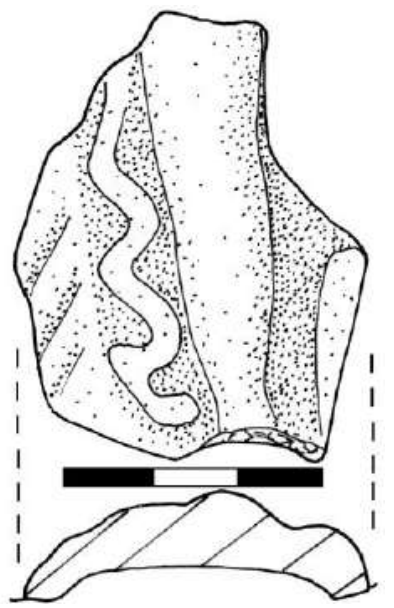

8. StATUETă (fragmentară). PI. III/8. Se păstrează un fragment din valva anterioară. Dr. 2016/232a, C23, carouri $10-12 \mathrm{a}-\mathrm{c},-1,88 \mathrm{~m}$. Pastă fină (arsă oxidant, neuniform) de culoare Munsell 5YR6/6 cu particule de mică, oxizi deși, particule calcar rare. Modelare în tipar (urme de la prelucrarea cu un obiect pe interior). Lut ars. $\mathrm{Lp}=4,78 \mathrm{~cm}, 1=2,84 \mathrm{~cm}, \mathrm{Gr}=0,84 \mathrm{~cm}$. Se păstrează o parte din corpul unei statuete reprezentând-o pe zeița Venus. O parte a antebrațului stâng, care este așezat pe draperie, iar cu degetele ține o parte a acesteia. La încheietura mâinii are o brățară lată. Nr. inv. pr. 111.

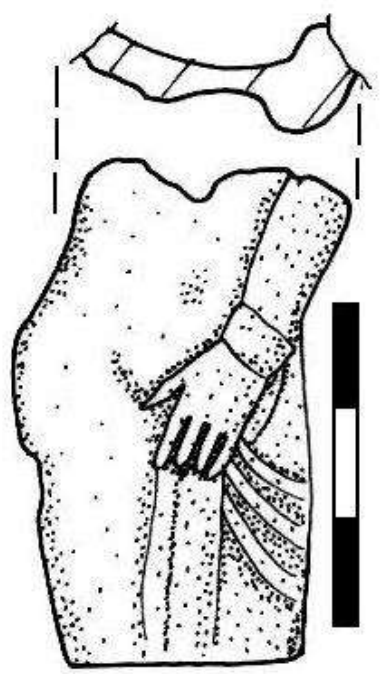

9. Statuetă (fragmentară). PI. III/9. Se păstrează un fragment din valva anterioară. Dr. 2008/127, C17, carouri 1-8e-f, $-1,11$ m. Pastă fină (arsă oxidant) de culoare Munsell 5YR6/8, cu particule de mică, oxizi relativ rari, particule calcar rare. Angobă de culoare Munsell 10YR7/3. Modelare în tipar; urme de amprente digitale la interior. Lut ars. $\mathrm{Lp}=4,27 \mathrm{~cm}, \mathrm{lp}=3,14 \mathrm{~cm}, \mathrm{Gr}=0,79 \mathrm{~cm} . \mathrm{Se}$ păstrează o porțiune din partea inferioară a unei statuete. Se observă un picior ușor flexat, acoperit de himation. Cel mai probabil statueta o reprezenta pe zeița Venus. Nr. inv. pr. 112.

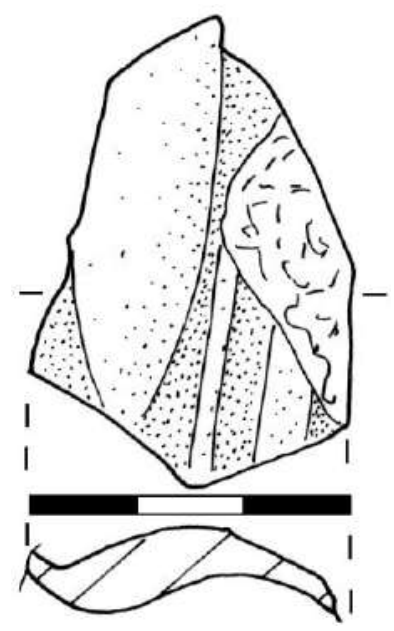

10. Statuetă (fragmentară). Pl. III/10. Se păstrează un fragment din valva anterioară. Dr. 2009/173, C18, caroul 2a, -1,44 m. Pastă fină (arsă oxidant) de culoare Munsell 5YR6/6, cu particule de mică, oxizi relativ deși, particule calcar dese. Modelare în tipar. Lut ars. $\mathrm{Lp}=3,68 \mathrm{~cm}, \mathrm{lp}=3,42$ $\mathrm{cm}, \mathrm{Gr}=1,02 \mathrm{~cm}$. Se distinge coapsa unui personaj feminin și faldurile veșmântului, cel mai probabil este reprezentată zeița Venus. Nr. inv. pr. 113.

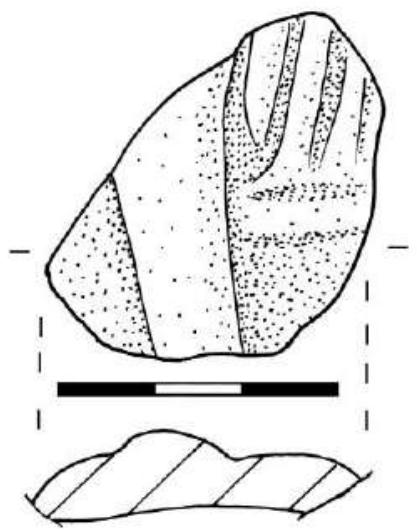

11. Statuetă (fragmentară). Pl. III/11. Se păstrează un fragment din valva anterioară. Dr. 2014/299, C18, carouri 3b-d, G23, -2,54 m. Pastă fină (arsă oxidant) de culoare Munsell 7.5YR8/3, cu particule de mică, oxizi rari, particule calcar rar. 
Modelare în tipar. Lut ars. $\mathrm{Lp}=4,96 \mathrm{~cm}, \mathrm{lp}=3,58$ $\mathrm{cm}, \mathrm{Gr}=0,98 \mathrm{~cm}$. Se păstrează o porțiune din coapsa dreaptă a unei statuete feminine, sub pubis este redată o buclă a draperiei. Nr. inv. pr. 114 .

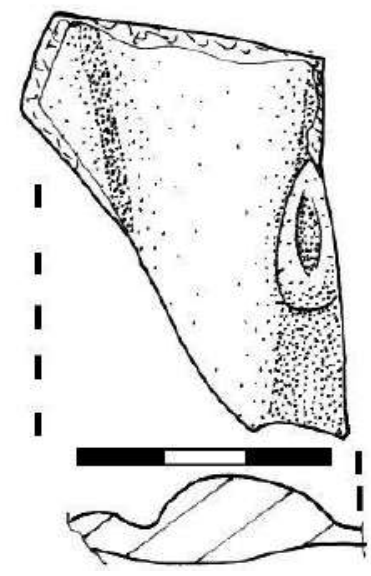

Analogii nr. 6-11: Ostrov, statuetă (lut): Muşețeanu, Elefterescu 1985b, pl. II/3; Nicopolis ad Istrum, statuete (lut): Vladkova 2012, fig. 1/1, $2 \mathrm{a}-\mathrm{b}, 3 \mathrm{a}-\mathrm{b}$.

12. STATUETă (fragmentară). Pl. III/12. Se păstrează un fragment din valva anterioară. Dr. 2014/48a, C18, carouri 3a-b,-2,05 m. Pastă fină (arsă reducător) de culoare Munsell 7.5YR6/4, cu particule de mică, oxizi relativ rari, particule calcar rare. Urme de firnis de culoare Munsell 10R5/8. Modelare în tipar, mici incizii în pasta crudă cu un obiect ascuțit. Lut ars. Lp $=7,41 \mathrm{~cm}, \mathrm{lp}=3,78 \mathrm{~cm}, \mathrm{Gr}=0,86 \mathrm{~cm}$. Se păstrează o porțiune din abdomenul inferior și coapsa dreaptă a unei statuete feminine. Este redat ombilicul. Cel mai probabil este o statuetă care o reprezintă pe zeița Venus. Nr. inv. pr. 115.

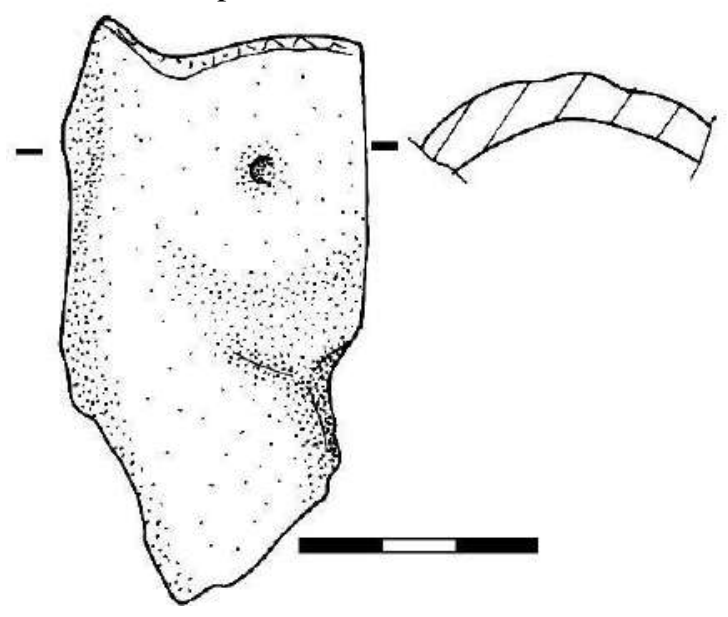

13. Statuetă (fragmentară). Pl. III/13. Se păstrează un fragment din valva posterioară. Dr. 2016/218, C23, caroul 11f, $-1,88$ m. Pastă fină (arsă oxidant) de culoare Munsell 5YR7/8 cu particule de mică, oxizi rar, particule calcar rare. Modelare în tipar, urme de la retușarea cu un obiect pe o latură a piesei. Lut ars. $L p=5,69 \mathrm{~cm}, 1=3,03$ $\mathrm{cm}, \mathrm{Gr}=0,46 \mathrm{~cm}$. Se păstrează o parte din corpul unei statuete reprezentând-o pe zeița Venus, respectiv o porțiune din spate, fesele și o parte din picioare, acoperite de fald. Nr. inv. pr. 116. Analogii: Ostrov, statuetă (lut): Muşeţeanu, Elefterescu 1985b, pl. II, fig. 6-7.

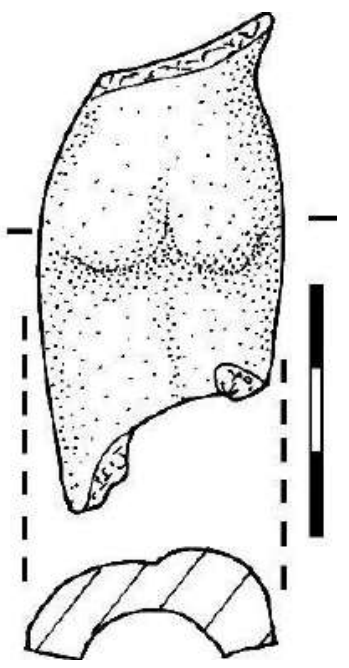

14. Statuetă (fragmentară). Pl. IV/14. Se păstrează un fragment din valva anterioară. Dr. 2008/344, C13-14, carouri 12-13 (demontare martor). Pastă fină (arsă oxidant) de culoare Munsell 5YR5/6, cu particule de mică, oxizi relativ rari, particule calcar rare. Urme ardere secundară pe suprafața interioară. Modelare în tipar. Lut ars. Lp $=3,70 \mathrm{~cm}, 1 \mathrm{p}=2,58 \mathrm{~cm}, \mathrm{Gr}=0,50 \mathrm{~cm}$. Se păstrează fața unei statuete masculine cu trăsături tinerești. Părul pieptănat pe spate, redat prin șuvițe paralele, cu ajutorul inciziilor lungi de la frunte spre spate. Fruntea îngustă, ochii bine conturați, alungiți, mari, au pupila marcată, pomeții proeminenți, nasul lat la bază, gura întredeschisă cu buzele groase, bărbia ascuțită, gât tubular, urechi mari, redate neanatomic. Nr. inv. pr. 117.

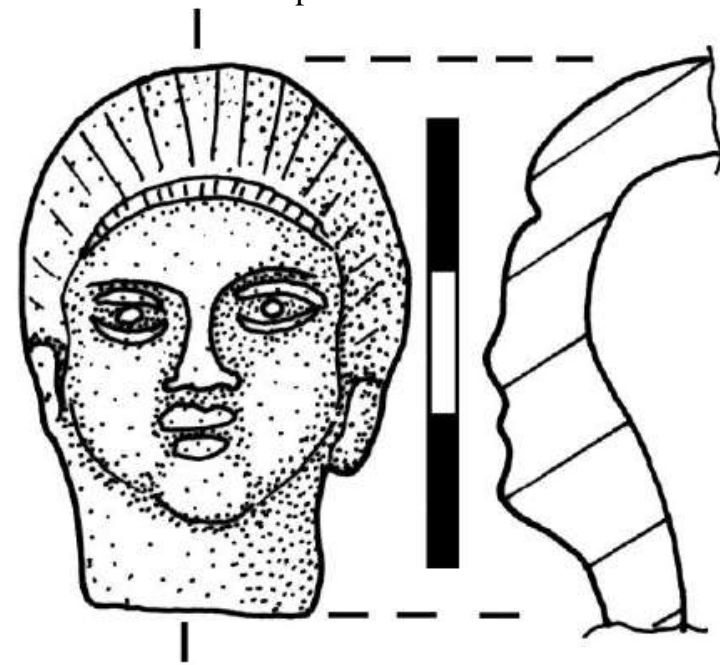

15. STATUETĂ (fragmentară). Pl. IV/15. Se păstrează un fragment din valva anterioară. Dr. 2011/189, C17, carouri 5-6e-f, $-2,10$ m. Pastă fină (arsă oxidant, neuniform) de culoare Munsell 5YR7/8 cu particule 
de mică, oxizi deși, particule calcar rare. Modelare în tipar. Lut ars. $\mathrm{Lp}=4,75 \mathrm{~cm}, 1=4,15 \mathrm{~cm}, \mathrm{Gr}=0,45$ $\mathrm{cm}$. Se păstrează un fragment din torsul și umărul drept ale unei statuete masculine. Sunt redați mușchii abdominali și ombilicul. Nr. inv. pr. 118.

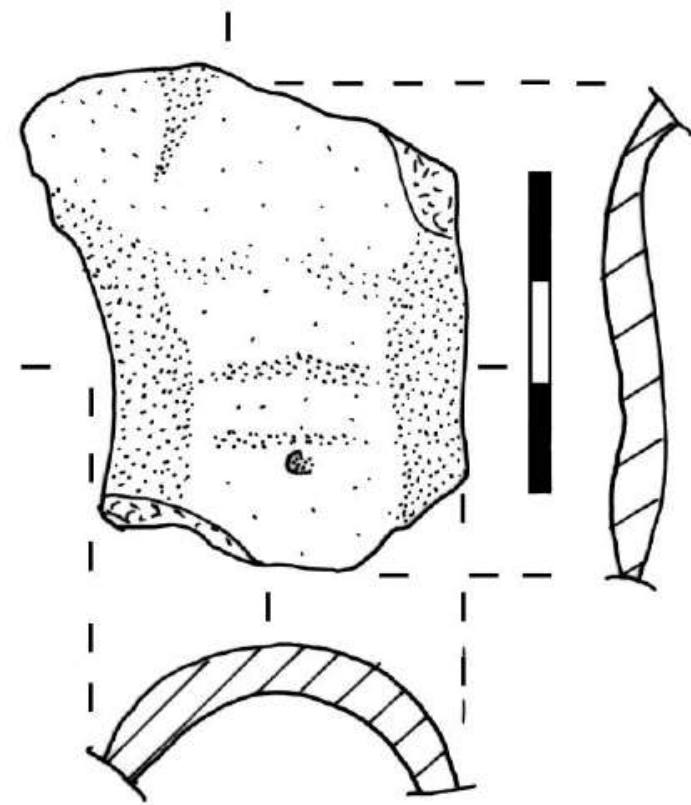

16. StAtUEtĂ (fragmentar). PI. IV/16. Se păstrează un fragment din valva anterioară. Dr. 2014/48b, C18, carouri $3 a-b,-2,05$ m. Pastă fină (arsă reducător) de culoare Munsell 7.5YR6/4, cu particule de mică, oxizi deși, particule calcar rare. Modelare în tipar (surplus de material de la prelucrare, la interior). Lut ars. $\mathrm{Lp}=6,78 \mathrm{~cm}, 1=$ $4,92 \mathrm{~cm}, \mathrm{Gr}=0,67 \mathrm{~cm}$. Se păstrează un fragment din bustul unei statuete masculine. Acesta este înveșmântat în mantie care este prinsă pe umărul drept cu un accesoriu de formă circulară. Mantia lasă să se întrevadă o parte a mamelonului drept. Bustul este așezat pe un soclu, dublu profilat, de formă circulară. Nr. inv. pr. 119.

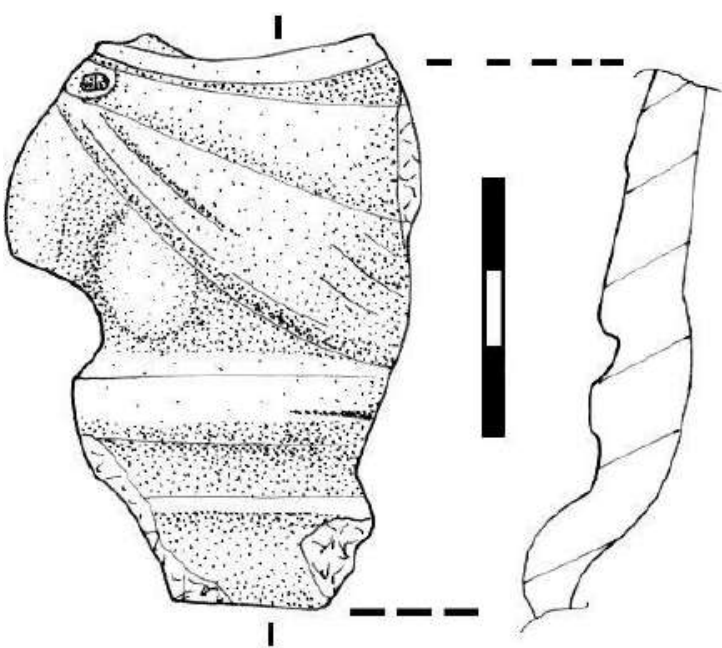

17. Statuetă (fragmentar). Pl. IV/17. Se păstrează un fragment din valva anterioară și cea posterioară. Dr. 2016/189b, C23, caroul 9c. Pastă fină (arsă oxidant) de culoare Munsell 5YR7/4 cu particule de mică, oxizi rari, particule calcar rare. Urme vopsea roșie? Modelare în tipar (surplus de material de la unirea celor două valve în interiorul piesei; urme de la retuşarea cu un obiect la îmbinarea celor două valve pe exterior). Lut ars. $\mathrm{Lp}=7,94 \mathrm{~cm}, 1=3,43$ $\mathrm{cm}, \mathrm{Gr}=0,52 \mathrm{~cm}$. Se păstrează fragmentul din partea stângă a bustului unei statuete masculine. Acesta este înveșmântat într-o mantie care formează falduri, redate prin incizii oblice, paralele. Spatele bustului este nedecorat. Bustul era așezat pe un soclu dublu profilat, de formă circulară, din care se păstrează doar un mic fragment. Nr. inv. pr. 120.
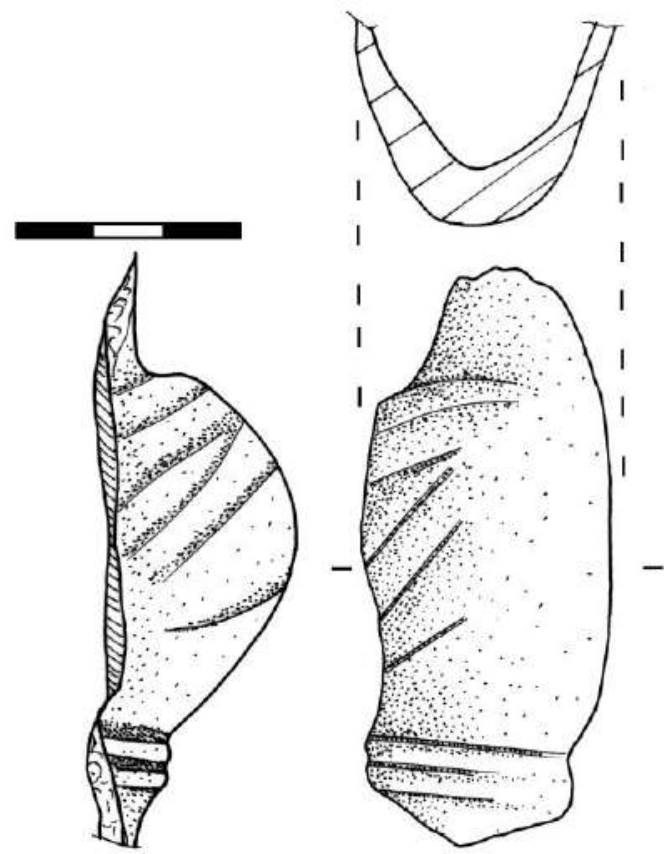

18. Statuetă (fragmentar). PI. IV/18. Se păstrează un fragment din valva posterioară. Dr. 2008/415, C18, carouri $2 \mathrm{a}-\mathrm{d},-1,26$ m. Pastă fină (arsă oxidant) de culoare Munsell 7.5YR8/6, cu particule de mică, oxizi rari, particule calcar rare. Modelare în tipar. Lut ars. $\mathrm{Lp}=6,25 \mathrm{~cm}, 1=4,66 \mathrm{~cm}, \mathrm{Gr}=$ $0,63 \mathrm{~cm}$. Se păstrează un fragment din spatele unui bust (nedecorat) și parte din soclu, de formă circulară, delimitat în partea superioară printr-o mulură. Nr. inv. pr. 121.

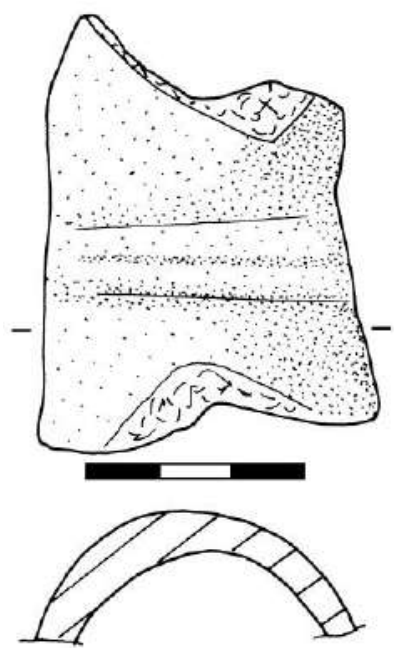


19. STATUETĂ (fragmentară). PI. IV/19. Se păstrează un fragment din valva posterioară. Dr. 2009/260, C17, caroul 3f, $-1,64$ m. Pastă fină (arsă oxidant) de culoare Munsell 10YR8/4, cu particule de mică, oxizi relativ rari, dar uneori sub formă de granule $(2-$ $3 \mathrm{~mm}$ ), particule calcar rare, dar uneori sub formă de granule $(1 \mathrm{~mm})$. Modelare în tipar, urme de amprente digitale pe interior. Lut ars. $\mathrm{Lp}=2,91 \mathrm{~cm}, 1 \mathrm{p}=4,95$ $\mathrm{cm}, \mathrm{Gr}=0,55 \mathrm{~cm}$. Se păstrează partea de sus a torsului unui personaj înveșmântat, ale cărui falduri sunt redate prin striații verticale, paralele, ușor oblic. In partea superioară se află un orificiu $(1 \times 0,50 \mathrm{~cm})$ realizat în pasta crudă, probabil pentru introducerea unui obiect din piatră sau metal. Nr. inv. pr. 122.

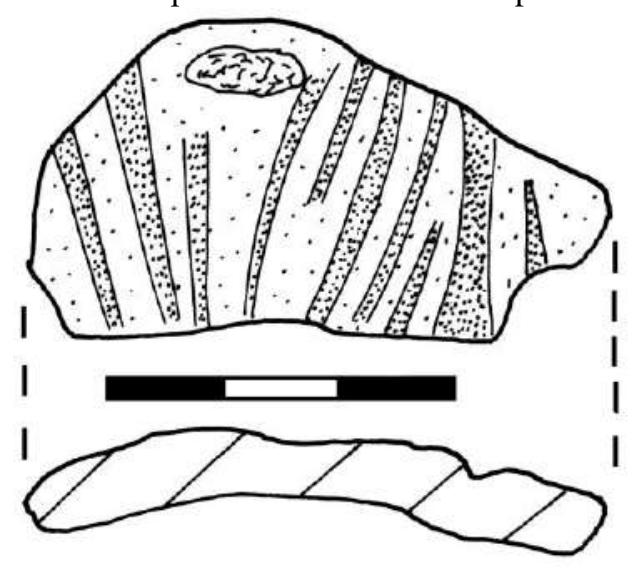

20. STATUETĂ (fragmentară). PI. IV/20. Se păstrează un fragment din valva anterioară. Dr. 2016/277, C23, caroul 13f, $-1,74 \mathrm{~m}$. Pastă fină (arsă oxidant) de culoare Munsell 7.5YR8/4 cu particule de mică, oxizi rari, particule calcar rare; mici goluri. Modelare în tipar. Lut ars. $\mathrm{Lp}=4,6 \mathrm{~cm}, 1=4,25 \mathrm{~cm}, \mathrm{Gr}=0,76 \mathrm{~cm}$. Se păstrează un fragment din torsul unei statuete masculine. Acesta este înveșmântat în tunică, prinsă de o centură subțire. Tunica este redată prin mici împunsături pe verticală, una sub alta, deasupra centurii și prin incizii verticale sub centură. Centura este decorată cu trei mici butoane circulare. O mică spărtură sub centură în partea stângă, din vechime. Nr. inv. pr. 123.

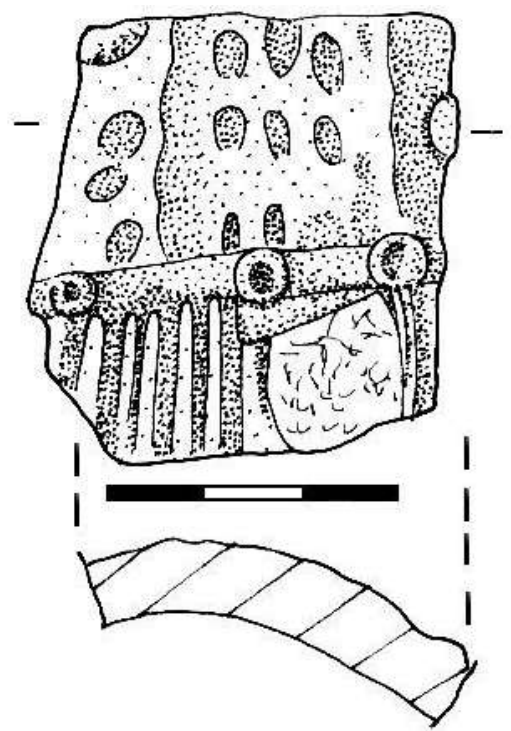

21. Statuetă (fragmentară). Pl. IV/21. Se păstrează un fragment din valva posterioară și un mic fragment din cea anterioară. Dr. 2016/393, C23, caroul 12b. Pastă fină (arsă oxidant) de culoare Munsell 7.5YR8/4, cu particule de mică, oxizi rari, particule calcar rare, dar uneori sub formă de granule (până la $6 \mathrm{~mm}$ ). Urme de depuneri la exterior. Modelare în tipar (surplus de material în partea interioară de la lipirea valvelor). Lut ars. $\mathrm{Lp}=4,95 \mathrm{~cm}, \mathrm{lp}=4,22 \mathrm{~cm}, \mathrm{Gr}=0,74 \mathrm{~cm}$. Se păstrează o porțiune din spatele unei statuete masculine şi o mică parte a braţului stâng. Veșmântul este decorat prin striații paralele, oblice, mai bine conturate pe braț. În talie veșmântul este redat ca și cum ar fi strâns, fără a se observa și o centură sau cordon. Nr. inv. pr. 124.

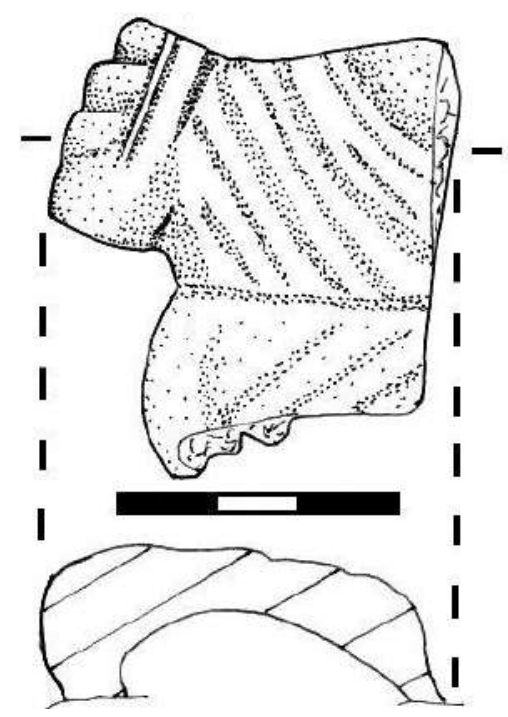

22. Statuetă (fragmentară). Pl. IV/22. Se păstrează un fragment din valva posterioară și un mic fragment din cea anterioară. Dr. 2014/79b, C18, carouri 3b-d, G23, -2,20 m. Pastă fină (arsă oxidant) de culoare Munsell 10YR8/3, cu particule de mică, oxizi relativ deși, particule de calcar rare, mici goluri şi fisuri; urme de vopsea? Modelare în tipar. Lut ars. $\mathrm{Lp}=4,53 \mathrm{~cm}, \mathrm{lp}=3,65 \mathrm{~cm}, \mathrm{Gr}=$ $0,64-1,19 \mathrm{~cm}$. Se păstrează un fragment din spatele unei statuete masculine, decorată cu linii paralele, uşor oblice, redând cutele mantiei. Nr. inv. pr. 125.

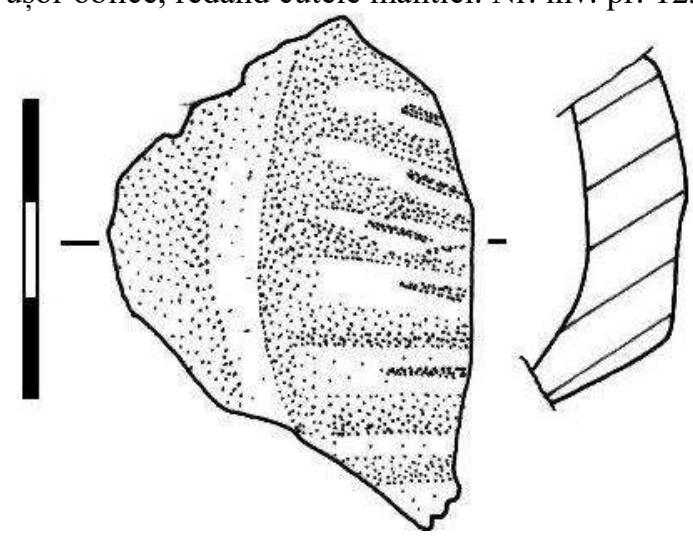


23. Statuetă (fragmentară). PI. V/23. Se păstrează un fragment din valva anterioară. Dr. 2016/207, C23, caroul 11d, $-1,88$ m. Pastă fină (arsă oxidant) de culoare Munsell 10YR8/3, cu particule de mică, oxizi rari, particule calcar rare. $\mathrm{Lp}=4,13 \mathrm{~cm}, \mathrm{lp}=$ $3,27 \mathrm{~cm}, \mathrm{Gr}=4,6 \mathrm{~cm}$. Lut ars. Modelare în tipar. Se păstrează partea de sus a torsului unui personaj masculin înveșmântat în tunică, ale cărei falduri formează un guler sub forma literei „V”. Brațul drept este îndoit și așezat pe piept, mâna ajungând la nivelul gulerului. Nr. inv. pr. 126.

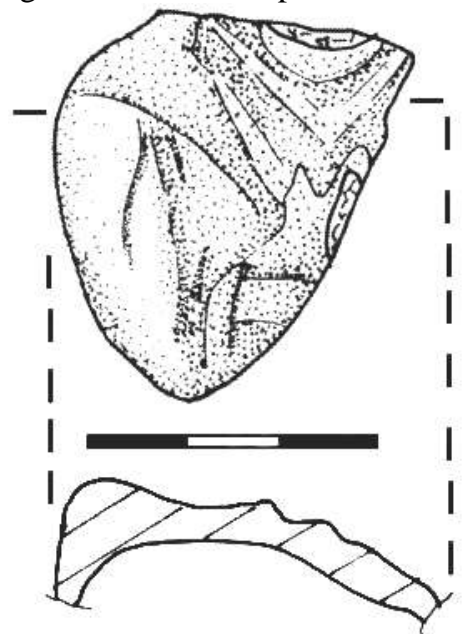

24. StAtuetă (fragmentară). Pl. V/24. Se păstrează un fragment din valva anterioară. Dr. 2014/79a, C18, carouri 3b-d, G23, -2,20 m. Pastă fină (arsă oxidant) de culoare Munsell 2.5YR7/8 cu particule de mică, oxizi deși, particule calcar rare. Lut ars. Modelare în tipar. $\mathrm{Lp}=6,15 \mathrm{~cm}, 1=5,60 \mathrm{~cm}, \mathrm{Gr}=$ $0,62-1,14 \mathrm{~cm}$. Se păstrează un fragment din torsul unei statuete masculine. Antebrațul drept este îndoit şi așezat pe torace. Mâna nu are degetele redate. Veșmântul, pe torace, este redat prin niște striații verticale, paralele, iar în zona gâtului este redat un guler? printr-o bandă lată. Nr. inv. pr. 127.

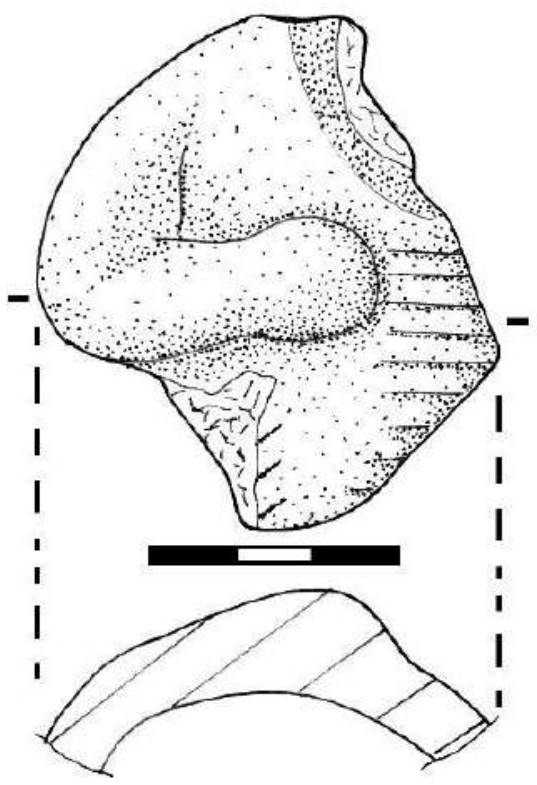

25. StATUETĂ (fragmentară). Pl. V/25. Se păstrează un fragment din valva anterioară. Dr. 2008/268,
C18, carouri $1 \mathrm{a}-\mathrm{d},-1,26$ m. Pastă fină (arsă oxidant) de culoare Munsell 5YR7/6, cu particule de mică, oxizi relativ rari, particule calcar rare. Modelare în tipar (surplus de material în interior de la lipirea valvelor). Lut ars. $\mathrm{Lp}=5,36 \mathrm{~cm}, \mathrm{lp}=4,26$ $\mathrm{cm}, \mathrm{Gr}=0,85 \mathrm{~cm}$. Un fragment dintr-o statuetă reprezentând un personaj din care se observă o parte din braț, lipsă umărul, antebraţul îndoit spre piept și palma, slab reprezentată. Nr. inv. pr. 128.

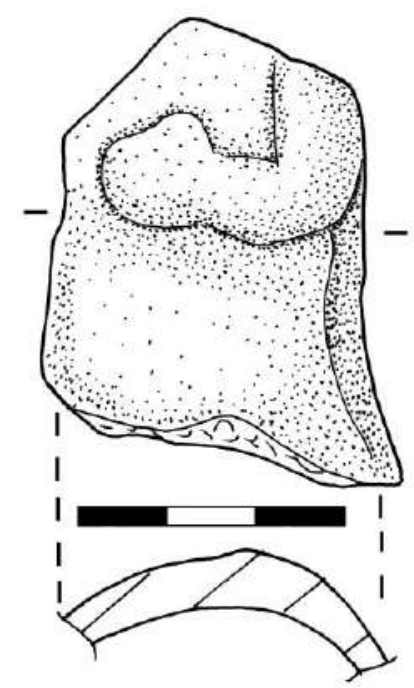

26. StATUETĂ (fragmentară). PI. V/26. Se păstrează un fragment din valva anterioară. Dr. 2008/100, C15, caroul $14 \mathrm{c},-0,69 \mathrm{~m}$. Pastă fină (arsă oxidant) de culoare Munsell 5YR7/6, cu particule de mică, oxizi rari, particule calcar rare. $\mathrm{La}$ exterior acoperită cu firnis de culoare Munsell 10R4/8. Lp = $2,73 \mathrm{~cm}, \mathrm{lp}=3,20 \mathrm{~cm}, \mathrm{Gr}=0,56 \mathrm{~cm}$. Modelare în tipar. Lut ars. Un fragment dintr-o statuetă reprezentând un personaj din care se observă antebrațul îndoit și palma, ale cărei degete sunt modelate neanatomic și disproporțional. Deasupra brațului se observă un decor circular, iar dedesubt mai multe puncte în relief. Nr. inv. pr. 129. Analogii: Nikopolis ad Istrum, statuetă (lut): Falkner 2007, 88, nr. 6.10, fig. 6.10.

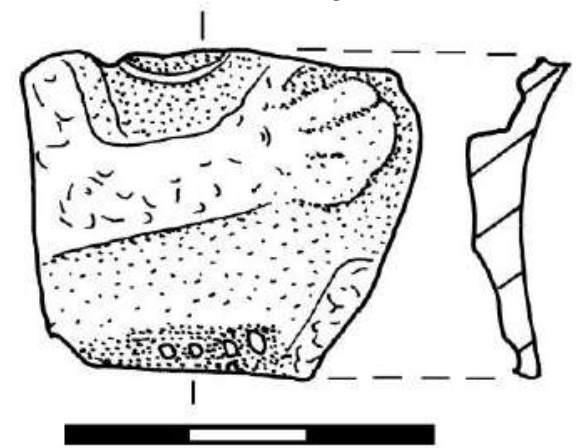

27. StAtUetă (fragmentară). PI. V/27. Se păstrează un mic fragment din valva anterioară și posterioară. Dr. 2014/68, C18, carouri 1-2c-d, $-2,15$ m. Pastă fină (arsă oxidant, neuniform) de culoare Munsell 5YR7/4, cu particule de mică, oxizi rari, particule de calcar relativ dese. Modelare în tipar (retuşări cu un obiect la îmbinarea celor două valve la exterior). Lut 
ars. $\mathrm{Lp}=6,64 \mathrm{~cm}, \mathrm{lp}=2,80 \mathrm{~cm}, \mathrm{Gr}=0,53 \mathrm{~cm} . \mathrm{Se}$ păstrează un fragment din antebrațul și cotul drept, îndoit, a unei statuete masculine. Nr. inv. pr. 130.

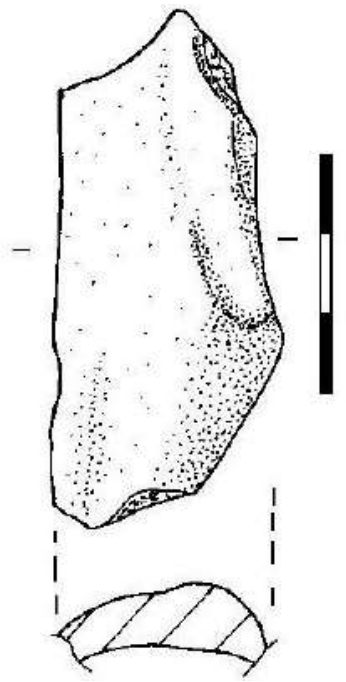

28. StAtuetă (fragmentară). Pl. V/28. Se păstrează un fragment din valva anterioară. Dr. 2014/281, C18, carouri $1-2 \mathrm{a}-\mathrm{d},-2,20 \mathrm{~m}$. Pastă fină (arsă oxidant, neuniform) de culoare Munsell 5YR8/4, cu particule de mică, oxizi rari, particule calcar rare. Modelare în tipar. Lut ars. $\mathrm{Lp}=5,65 \mathrm{~cm}, \mathrm{lp}=3,05$ $\mathrm{cm}, \mathrm{Gr}=0,58 \mathrm{~cm}$. Se păstrează un fragment pe care se observă antebrațul și cotul mâinii drepte a unei statuete masculine. Nr. inv. pr. 131.

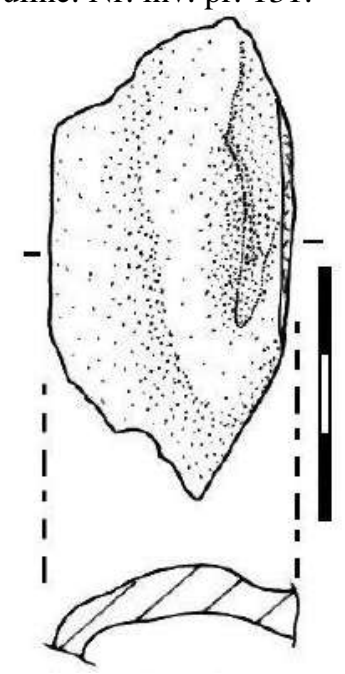

29. StAtUETĂ (fragmentară). PI. V/29. Se păstrează un fragment din valva anterioară. Dr. 2008/377, C17, carouri $5 \mathrm{e}-\mathrm{h},-0,40-0,45$ m. Pastă fină (arsă până aproape de vitrifiere), cu particule de mică, oxizi rari, particule calcar relativ dese. Modelare în tipar. Lut ars. $\mathrm{Lp}=4,86 \mathrm{~cm}, \mathrm{lp}=3,25 \mathrm{~cm}, \mathrm{Gr}=$ $0,48 \mathrm{~cm}$. Un fragment dintr-o statuetă reprezentând un personaj din care se observă brațul și o parte din antebrat poziționat pe torace, orientat în sus. Nr. inv. pr. 132.

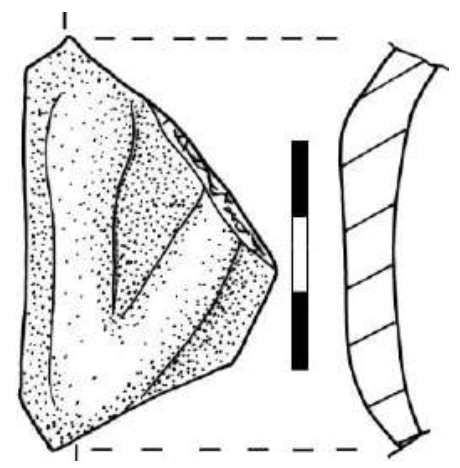

30. Statuetă (fragmentară). Pl. VI/30. Se păstrează un fragment din valva anterioară. Dr. 2014/308, demontare martor C18-19, -1,72 m. Pastă fină (arsă oxidant) de culoare Munsell 5YR7/8 cu particule de mică, oxizi rari, particule calcar rare. Lut ars. Modelare în tipar. $\mathrm{Lp}=3,55$ $\mathrm{cm}, 1=2,94 \mathrm{~cm}, \mathrm{Gr}=0,56 \mathrm{~cm}$. Se păstrează un fragment din torsul unei statuete masculine. Antebrațul drept este îndoit și așezat pe torace. $\mathrm{Nr}$. inv. pr. 133.

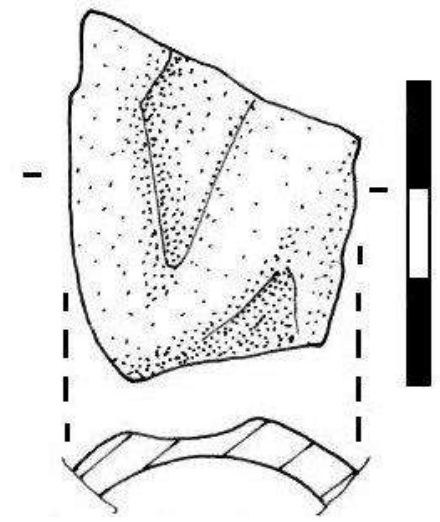

31. Statuetă (fragmentară). PI. VI/31. Se păstrează un fragment din valva anterioară. Dr. 2014/358, C18, caroul 3b-c, G23, -2,15 m. Pastă fină, caolinoasă, de culoare Munsell 7.5YR9,5/1, oxizi deși. Lp = 3,80 $\mathrm{cm}, \mathrm{lp}=3,77 \mathrm{~cm}, \mathrm{Gr}=0,86 \mathrm{~cm}$. Modelare în tipar. Lut ars. Se păstrează un fragment dintr-o statuetă reprezentând un personaj din care se observă brațul și antebrațul îndoit, poziționat pe torace, orientat în sus. Degetele sunt modelate neanatomic şi disproporțional. Nr. inv. pr. 135.

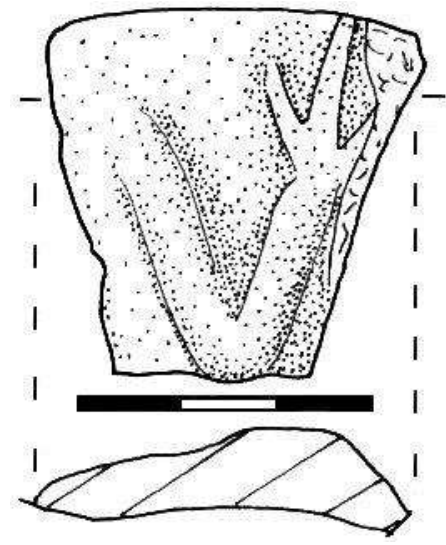


Analogii nr. 27-31: Butovo, statuetă (lut): Sultov 1976, 92; Ostrov, statuete (lut): Bâltâc, Știrbulescu 2007-2008, 178, nr. 39-40, pl. 11/39-40.

32. StATUETĂ (fragmentară). Pl. VI/32. Se păstrează un fragment din valva anterioară. Dr. 2009/339, C18, carouri 5 a-d, $-1,60$ m. Pastă fină (arsă oxidant) de culoare Munsell 5YR6/6, cu particule de mică dese, oxizi deși, particule calcar rare. Modelare în tipar (urme de la amprentele digitale pe suprafața interioară). Lut ars. $\mathrm{Lp}=3,13$ $\mathrm{cm}, \mathrm{lp}=3,06 \mathrm{~cm}, \mathrm{Gr}=0,57 \mathrm{~cm}$. Se observă o parte dintr-o palmă care ține un obiect (posibil două tije cu capsule de mac). Nr. inv. pr. 135.

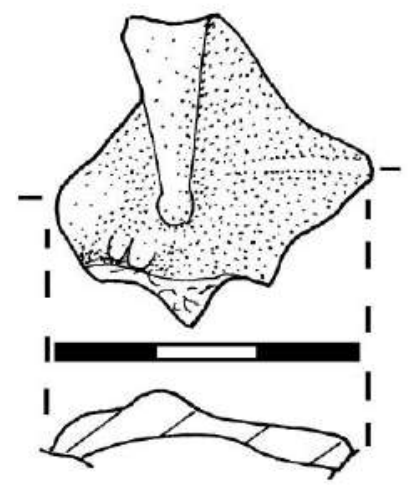

33. Statuetă (fragmentară). Pl. VI/33. Se păstrează un fragment din valva anterioară. Dr. 2013/207, C21b. Pastă fină (arsă oxidant) de culoare Munsell 5YR6/6, cu particule de mică, oxizi relativ rari, particule calcar rare. Modelare în tipar (urme de la amprentele digitale pe interior). Lut ars. $\mathrm{Lp}=2,48 \mathrm{~cm}, \mathrm{lp}=1,69 \mathrm{~cm}, \mathrm{Gr}=0,33 \mathrm{~cm}$. Se păstrează palma și un fragment din brațul întins pe lângă corp dintr-o statuetă masculină? Nr. inv. pr. 136.

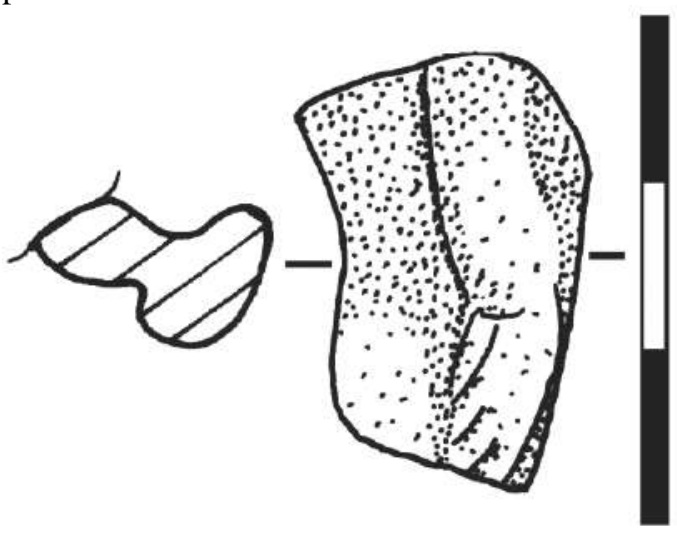

34. Statuetă (fragmentară). PI. VI/34. Se păstrează un fragment din valva anterioară. Dr. 2013/154, C19-21 (martor). Pastă fină (arsă reducător) de culoare Munsell 7.5YR8/4, cu particule de mică, oxizi deși, particule de calcar dese. $\mathrm{Lp}=4,50 \mathrm{~cm}, \mathrm{lp}=4,57 \mathrm{~cm}, \mathrm{Gr}=0,10 \mathrm{~cm}$. Modelare în tipar (urme de la retușare cu un obiect, pe interior; urme de amprente digitale pe interior). Lut ars. Se păstrează un fragment din torsul și umărul unei statuete. Nr. inv. pr. 137.

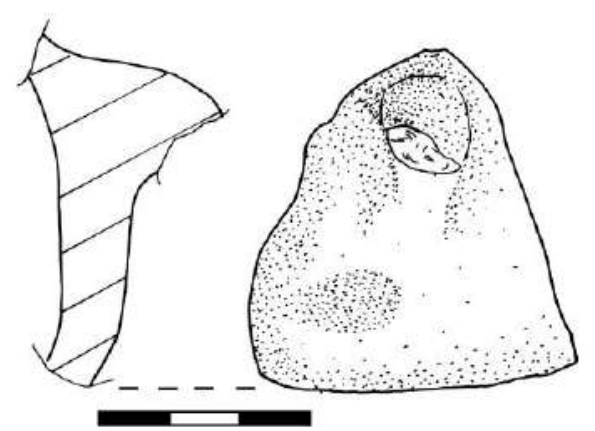

35. Statuetă (fragmentară). Pl. $\quad$ VI/35. Se păstrează cea mai mare parte a valvei anterioare (fără cap) și o mică parte din valva posterioară (10\%). Dr. 2008/217, C17, caroul 8a, -1,04 m. Pastă fină (arsă oxidant) de culoare Munsell 10YR7/8, cu particule de mică, oxizi rari, particule de calcar rare. Modelare în tipar (surplus de material în interior, mai ales la îmbinarea dintre valve; urme de retușare în pasta crudă cu un obiect ascutit pe spate). Lut ars. $\mathrm{Lp}=8,86 \mathrm{~cm}, 1=4,48$ $\mathrm{cm}, \mathrm{Gr}=0,74 \mathrm{~cm}$. Se păstrează cea mai mare parte (lipsă capul) a unei statuete feminine, care este redată în picioare, înveșmântată cu tunică și chiton. Faldurile veșmântului sunt redate prin incizii oblice, paralele, care formează o rețea, iar unele incizii din zona pieptului se unesc, astfel încât creează iluzia literei „V” „căzută”. Palma mâinii drepte se zărește la piept, sub gât, iar palma mâinii stângi este redată în prelungirea unei incizii a faldului și este ținută pe abdomen. Picioarele, neanatomic realizate, se zăresc de sub veșmânt. În partea inferioară este trasată o linie incizată. Partea conservată din valva posterioară nu păstrează urme de decor. Nr. inv. pr. 138. Analogii: Barboşi statuetă (lut):, Dragomir 1996, 411, fig. 5/2.

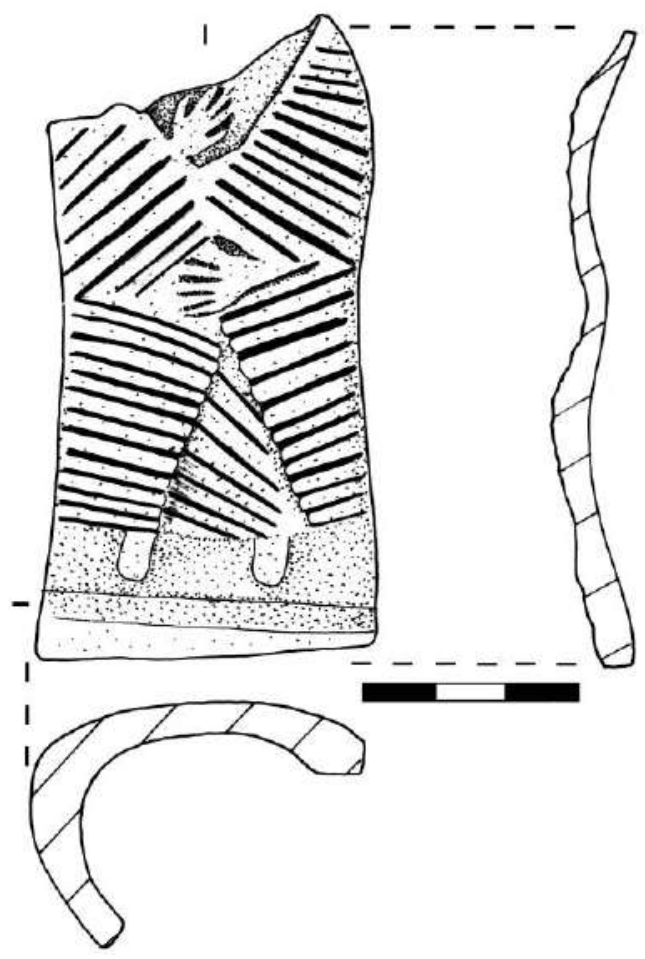


36. STATUETĂ (fragmentară). PI. VI/36. Se păstrează un fragment din valva anterioară. Dr. 2012/43, C21, caroul $12 \mathrm{a},-1,45 \mathrm{~m}$. Pastă fină (arsă oxidant) de culoare Munsell 10YR7/4, cu particule de mică, oxizi relativ deși, uneori sub formă de granule (până la $4 \mathrm{~mm}$ ), particule de calcar rare. Modelare în tipar (urme de amprente digitale la interior). Lut ars. Lp = $3,89 \mathrm{~cm}, \mathrm{lp}=2,75 \mathrm{~cm}, \mathrm{Gr}=0,81 \mathrm{~cm}$. Se păstrează fața unei statuete feminine cu trăsături tinerești. Fruntea lată, ochii mari cu pupila marcată, nas subțire care se lățește la bază, gura închisă, cu buze groase, bărbia ascuțită. Părul este pieptănat cu cărare pe mijloc și capul acoperit cu văl. Nr. inv. pr. 138.

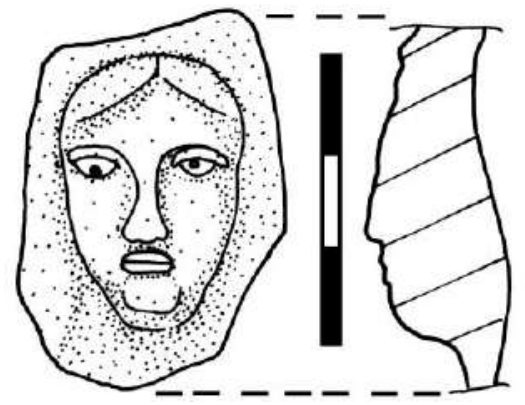

37. Statuetă (fragmentară). Pl. VI/37. Se păstrează un fragment din valva anterioară. Dr. 2008/139, C18, caroul $7 \mathrm{c},-1,28 \mathrm{~m}$. Pastă fină (arsă oxidant) de culoare Munsell 2.5YR6/8, cu particule de mică, oxizi relativ rari, particule de calcar rare. Angobă de culoare Munsell 7.5YR6/6. Modelare în tipar (urme de la retuşare cu un obiect ascuțit la exterior; urme de la amprentele digitale în interior). Lut ars. $\mathrm{Lp}=4,36$ $\mathrm{cm}, \mathrm{lp}=2,90 \mathrm{~cm}, \mathrm{Gr}=0,50 \mathrm{~cm}$. Se păstrează fața unei statuete feminine velate, cu trăsăturile fizionomice foarte șterse. Nr. inv. pr. 139.

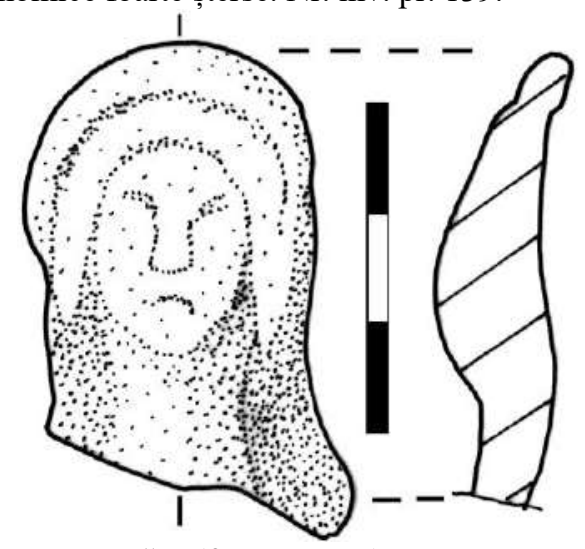

38. Statuetă (fragmentară). Pl. VI/38. Se păstrează valva anterioară. Dr. 2010/179, C19, carouri $12-17 \mathrm{c}-\mathrm{d},-1,50-1,61$ m. Pastă fină (arsă reducător) de culoare Munsell 7.5YR6/6, cu particule de mică, oxizi rari, particule calcar rare. $\mathrm{Lp}=3,28 \mathrm{~cm}, 1 \mathrm{p}=2,77 \mathrm{~cm}, \mathrm{Gr}=0,61 \mathrm{~cm}$. Modelare în tipar (urme de amprente digitale pe interior). Lut ars. Se păstrează fața unui personaj feminin, redat cu nasul proeminent, bărbia grosolană. Pe cap poartă văl. Trăsăturile feței sunt şterse, cel mai probabil de la folosirea tiparului excesiv. Nr. inv. pr. 140.

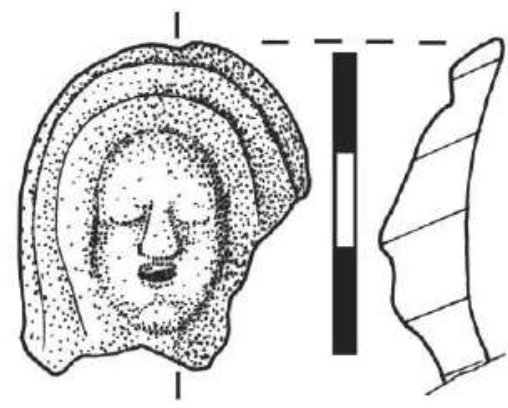

39. Statuetă (fragmentară). Pl. VII/39. Se păstrează un fragment din valva anterioară. Dr. 2014/134b, C18, caroul 3b-d (G23), -2,54 m. Pastă fină (arsă oxidant), de culoare Munsell 7.5YR8/6, cu particule de mică, oxizi rari, particule de calcar rare. Lut ars. Modelare în tipar. Lp = $3 \mathrm{~cm}, 1$ max. $=3,13$ $\mathrm{cm}, \mathrm{Gr}=0,51 \mathrm{~cm}$. Se păstrează fața unei statuete feminine cu trăsăturile fizionomice foarte șterse. Ochii slab conturați, nasul proeminent, gura nu se observă. Pe cap poartă un văl. Nr. inv. pr. 141.

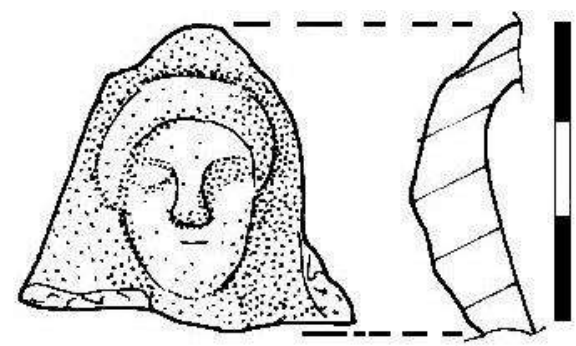

40. StAtuetă (fragmentară). PI. VII/40. Se păstrează un fragment din valva anterioară. Dr. 2008/385, C18, carouri 7-8a-d, $-1,43$ m. Pastă fină (arsă oxidant) de culoare Munsell 10YR7/3, cu particule de mică, oxizi relativ rari, particule de calcar rare. $L p=3,65 \mathrm{~cm}, l p=$ $2,04 \mathrm{~cm}, \mathrm{Gr}=0,70 \mathrm{~cm}$. Modelare în tipar. Lut ars. Se păstrează fața unei statuete feminine, cu trăsăturile feței foarte șterse, din care se observă ochiul stâng, sprâncenele, nasul proeminent și gura. Părul este redat cu cărare pe mijloc, pe cap are un acoperământ de formă semicirculară. Nr. inv. pr. 142.

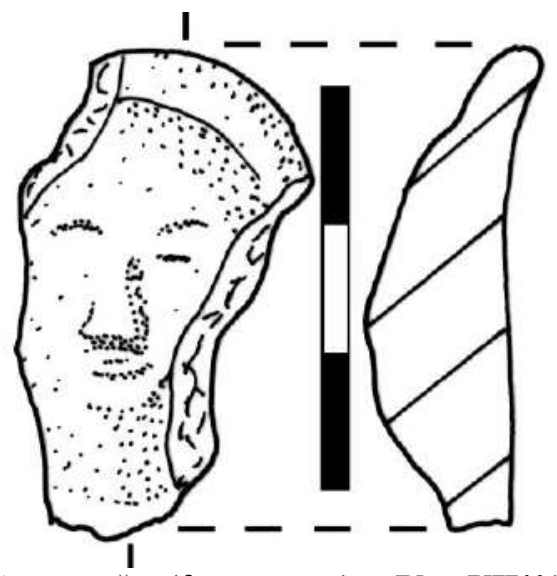

41. Statuetă (fragmentară). Pl. VII/41. Se păstrează un fragment din valva anterioară. Dr. 2016/286, C23, carourile 10-12a-c, -1,88 m. Pastă fină (arsă oxidant), de culoare Munsell 5YR7/4, cu 
particule de mică, oxizi, particule de calcar rare. Modelare în tipar (în zona bărbiei un accident în pasta crudă). Lut ars. $\mathrm{Lp}=3,56 \mathrm{~cm}, 1$ max. $=2,54$ $\mathrm{cm}, \mathrm{Gr}=0,64 \mathrm{~cm}$. Se păstrează cea mai mare parte din capul unei statuete feminine cu unele trăsături fizionomice șterse. Ochii slab conturați, cu pupila marcată, nasul slab profilat. Părul este redat pe frunte prin incizii radiale; pe cap pare a purta un văl. Pe marginea piesei este redat un decor prin incizii vălurite. Nr. inv. pr. 143.

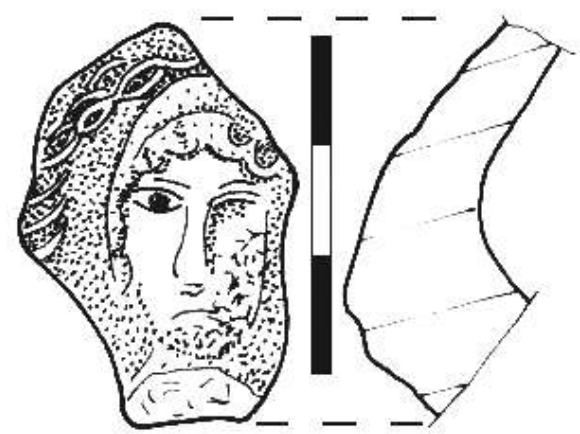

42. Statuetă (fragmentară). Pl. VII/42. Se păstrează un fragment din valva anterioară. Dr. 2014/163c, C18, caroul 3b-d (G23). Pastă fină (arsă oxidant, neuniform), de culoare Munsell 7.5YR7/4, cu particule de mică, oxizi, particule de calcar rare. Modelare în tipar (urme digitale pe suprafața interioară; pe obrazul drept un accident din fabricație; pe gât și în zona stângă a tâmplei incizii în pasta crudă). Lut ars. $\mathrm{Lp}=6 \mathrm{~cm}, 1$ max. $=$ $5,11 \mathrm{~cm}, \mathrm{Gr}=0,66 \mathrm{~cm}$. Se păstrează fața unei statuete feminine cu trăsăturile fizionomice foarte şterse. Ochii abia conturați. Nasul proeminent, gura slab marcată. Coafura este ascunsă de un acoperământ de formă conică, redat prin cinci muluri paralele. Nr. inv. pr. 144.

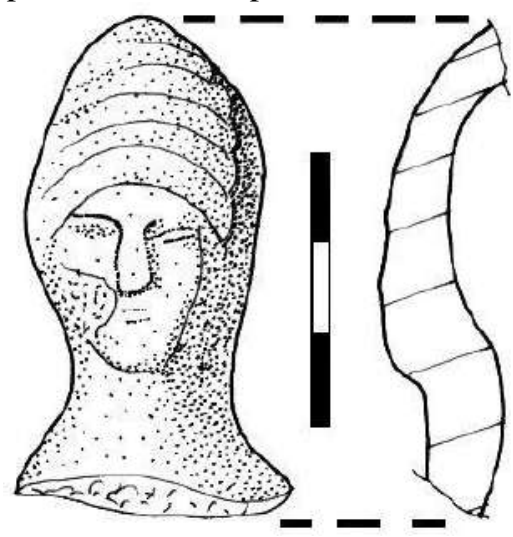

43. Statuetă (fragmentară). Pl. VII/43. Se păstrează un fragment din valva anterioară. Dr. 2008/213, C17, carouri 5-6 g-h, -1,16-1,27 m. Pastă fină (arsă oxidant) de culoare Munsell 10YR7/4, cu particule de mică, oxizi relativ rari, mici fisuri. Modelare în tipar. Lut ars. $L p=3,54$ $\mathrm{cm}, \mathrm{lp}=2,64 \mathrm{~cm}, \mathrm{Gr}=1,11 \mathrm{~cm}$. Se păstrează fața unei statuete feminine cu trăsăturile șterse. Părul acoperă urechile, iar pe cap este un acoperământ de formă conică, redat prin trei muluri paralele. Nr. inv. pr. 145 .

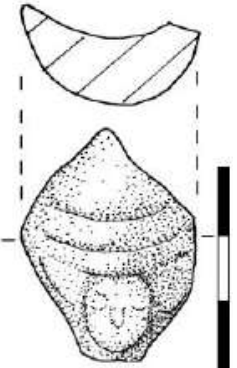

44. Statuetă (fragmentară). Pl. VII/44. Se păstrează valva anterioară și posterioară a unui cap de statuetă, nasul spart. Dr. 2012/89, C21, caroul $16 d,-1,65$ m. Pastă fină (arsă oxidant) de culoare Munsell 5YR6/6, cu particule de mică, oxizi diverși, particule de calcar rare, granule de ceramică (de până la $3 \mathrm{~mm}$ ). În zona ochiului și a obrazului drept urme de vopsea sau firnis; pe față urme de vopsea? de culoare albă. Modelare în tipar. Lut ars. Lp = 4,97 cm, $\operatorname{lmax}=3,20 \mathrm{~cm}, \mathrm{Gr}=0,60$ cm. Fruntea lată, ochii mici, fără pupilă marcată, gura cu buzele închise. Coafura este redată de pe frunte până pe creștet prin fâșii paralele incizate, iar la spate prin impresiuni dese, model realizat în tipar. La unirea celor două valve, pe laterale și creștet, în pasta crudă s-au realizat incizii paralele, care modifică modelul din tipar și completează coafura. Nr. inv. pr. 146.

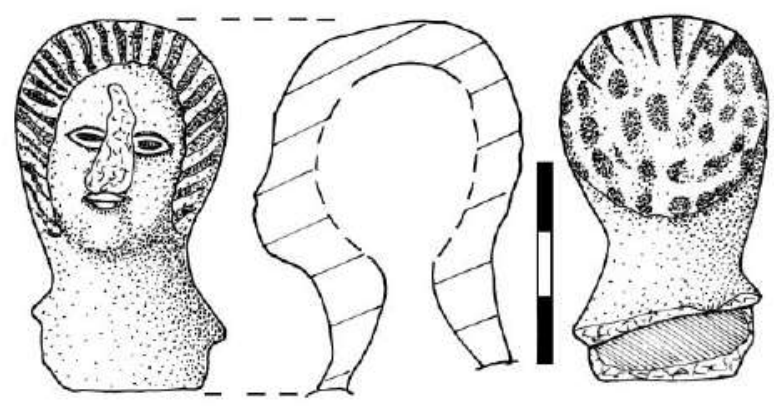

45. Statuetă (fragmentară). Pl. VII/45. Se păstrează un fragment din valva anterioară. Dr. 2012/91, C21, caroul 17d, -1,75 m. Pastă fină (arsă oxidant) de culoare Munsell 2YR7/8, cu particule de mică, oxizi relativ rari, particule de calcar rare. Urme de vopsea? Modelare în tipar. Lut ars. Lp = $3,94 \mathrm{~cm}, \mathrm{lp}=2,62 \mathrm{~cm}, \mathrm{Gr}=0,48 \mathrm{~cm}$. Se păstrează fața unei statuete feminine cu trăsături foarte șterse. Ochii mari abia conturați, nas ușor lățit la bază, gura cu buzele închise. Obraji bucălați. Fața este încadrată de un văl sau de coafură. Nr. inv. pr. 147.

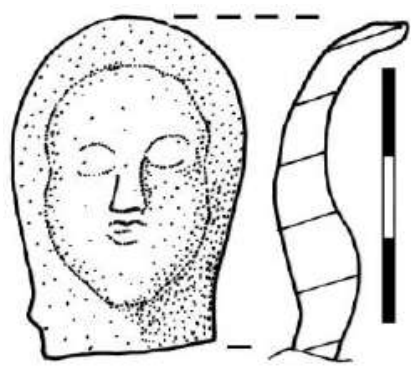


46. Statuetă (fragmentară). Pl. VII/46. Se păstrează un fragment din valva anterioară. Dr. 2013/41, C23a, carouri 10-17a-f, -1,17 m. Pastă fină (arsă oxidant) de culoare Munsell 10YR7/4, cu particule de mică, oxizi rari, particule de calcar rare, mici fisuri. Modelare în tipar. Lut ars. Lp = $2,95 \mathrm{~cm}, \mathrm{lp}=2,10 \mathrm{~cm}, \mathrm{Gr}=0,56 \mathrm{~cm}$. Se păstrează fața unei statuete feminine (?) cu trăsăturile fizionomice foarte șterse, se observă doar nasul. În zona ochiului stâng trei linii incizii fine în pasta crudă. Nr. inv. pr. 148.
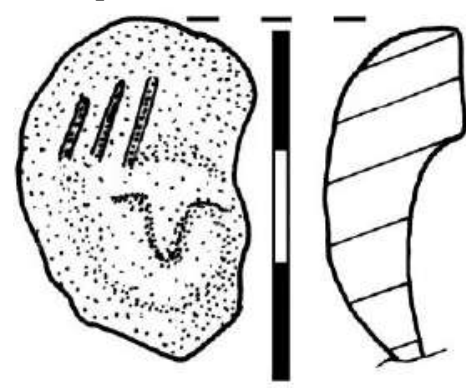

47. Statuetă (fragmentară). Pl. VII/47. Se păstrează un fragment din valva anterioară. Dr. 2014/148a, C18 (G23), -2,54, m. Pastă fină (arsă oxidant, neuniform) de culoare Munsell 7.5YR8/4, cu particule de mică, oxizi relativ deși, uneori sub formă de granule (de până la $2 \mathrm{~mm}$ ), particule de calcar rare. Modelare în tipar. Lut ars. Lp $=3,86$, $\mathrm{cm}, \mathrm{lp}=3,57 \mathrm{~cm}, \mathrm{Gr}=8,33 \mathrm{~cm}$. Se păstrează un mic fragment din capul și gâtul unei statuete. Din figură se păstrează un fragment din obrazul stâng, bărbie şi gură. Pe gât un decor (?) din linii paralele, ușor oblice. Nr. inv. pr. 149.

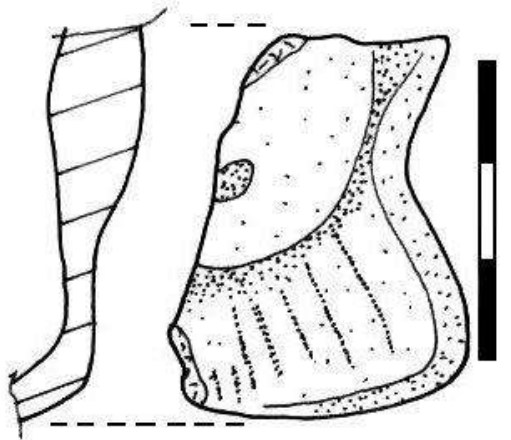

48. Statuetă (fragmentară). Pl. VIII/48. Se păstrează un fragment din valva posterioară. Dr. 2014/7b, demontare martor C18-19. Pastă fină (arsă reducător) de culoare Munsell 7.5YR7/4, cu particule de mică, oxizi relativ deși, particule calcar rare. Modelare în tipar (surplus de material spre creștet; urme de la prelucrarea pe interior). Lut ars. $\mathrm{Lp}=5,48 \mathrm{~cm}, \mathrm{lp}=4,08 \mathrm{~cm}, \mathrm{Gr}=4,64 \mathrm{~cm}$. Se păstrează partea dorsală a capului unei statuete feminine. Coafura redă o împletitură, realizată prin striații oblice, paralele, care formează litera „V”. Nr. inv. pr. 150.

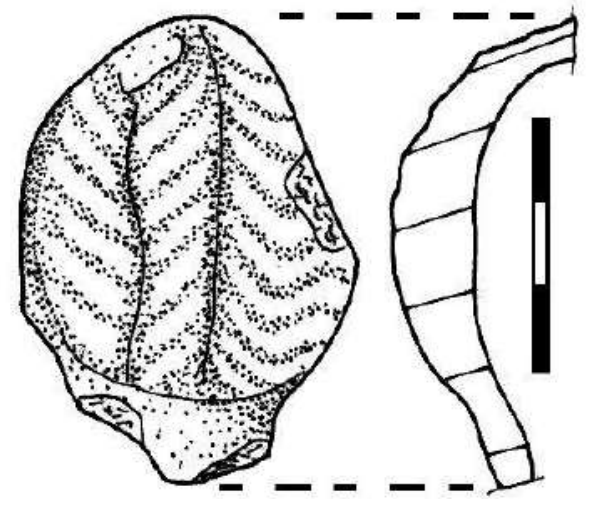

49. Statuetă (fragmentară). Pl. VIII/49. Se păstrează valva posterioară. Dr. 2010/228, C19, carouri 10-12a-b, -1,45-1,50 m. Pastă fină (arsă oxidant) de culoare Munsell 5YR7/6, cu particule de mică, oxizi rari, particule de calcar rare. $\mathrm{Lp}=$ $4,41 \mathrm{~cm}, \mathrm{lp}=3,70 \mathrm{~cm}, \mathrm{Gr}=0,73 \mathrm{~cm}$. Modelare în tipar. Lut ars. Se păstrează partea dorsală capului unei statuete. Prin incizii vălurite, realizate cu un obiect ascuțit după modelare, sunt redate buclele unei coafuri. Nr. inv. pr. 151.

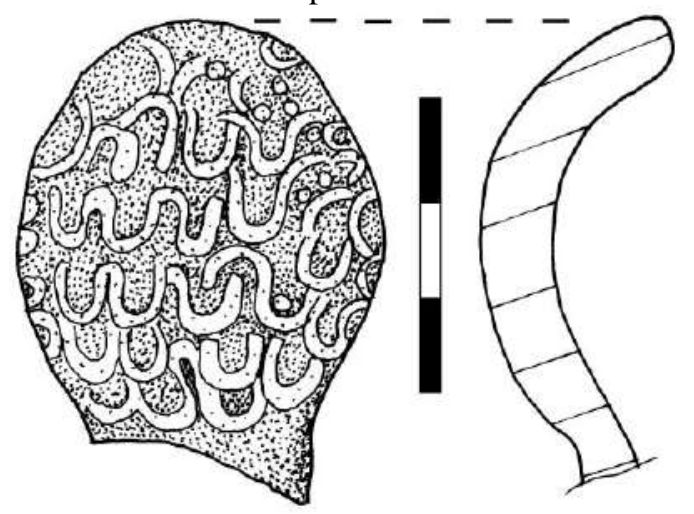

50. Statuetă (fragmentară). Pl. VIII/50. Se păstrează un fragment din valva posterioară. Dr. 2008/151, C18, caroul 6c, -1,28 m. Pastă fină (arsă oxidant) de culoare Munsell 5YR7/4, cu particule de mică, oxizi relativ rari, particule de calcar rare. Modelare în tipar. Lut ars. $\mathrm{Lp}=3,16 \mathrm{~cm}, 1 \mathrm{p}=2,50$ $\mathrm{cm}, \mathrm{Gr}=0,46 \mathrm{~cm}$. Se păstrează partea dorsală a capului unei statuete feminine. Părul este strâns într-un coc prins la nivelul cefei. Nr. inv. pr. 152.

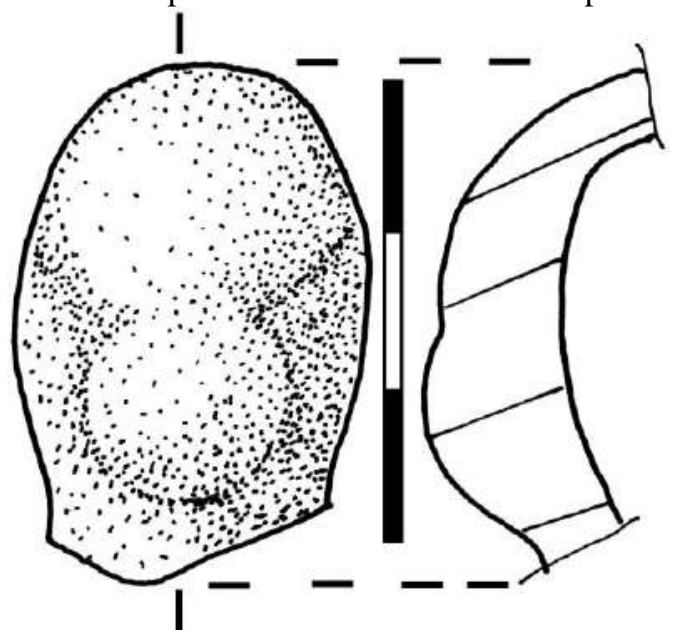


51. Statuetă (fragmentară). Pl. VIII/51. Se păstrează un fragment din valva posterioară și unul mic din cea anterioară. Dr. 2014/7c, demontare martor C18-19. Pastă fină (arsă oxidant) de culoare Munsell 10YR8/3, cu particule de mică, oxizi rari, particule de calcar rare. $\mathrm{Lp}=3,62 \mathrm{~cm}, 1 \mathrm{p}=2,55 \mathrm{~cm}$, $\mathrm{Gr}=0,60 \mathrm{~cm}$. Modelare în tipar (surplus de material la unirea celor două valve, la interior). Lut ars. Se păstrează partea dorsală a capului unei statuete umane. Nu se păstrează detalii ale coafurii. Nr. inv. pr. 153.

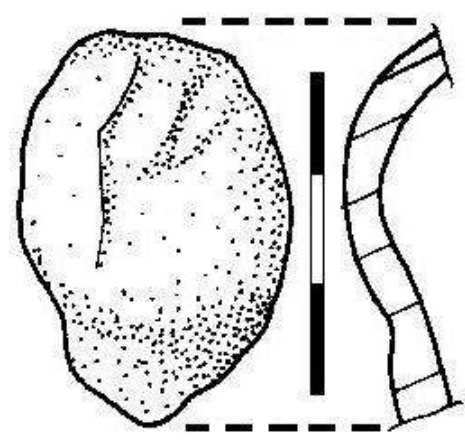

52. Statuetă (fragmentară). Pl. VIII/52. Se păstrează un fragment din valva posterioară. Dr. 2011/224, C19, carouri 9-10 c-d. Pastă fină (arsă oxidant) de culoare Munsell 5YR7/6, cu particule de mică, particule de calcar rar, dar sub formă de granule (până la $2 \mathrm{~mm}$ ). $\mathrm{Lp}=2,57 \mathrm{~cm}, \mathrm{lp}=2,35$ $\mathrm{cm}, \mathrm{Gr}=0,49 \mathrm{~cm}$. Modelare în tipar; surplus de material de la prelucrare, pe interior. Lut ars. Se păstrează partea dorsală a capului unei statuete umane. Nu se păstrează detalii ale coafurii. Nr. inv. pr. 154

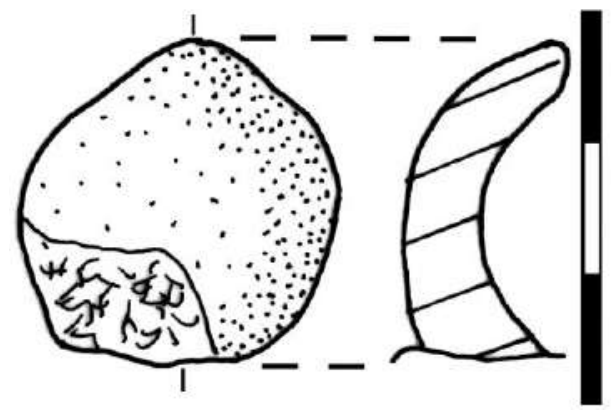

53. Statuetă (fragmentară). Pl. VIII/53. Se păstrează un fragment din valva posterioară și anterioară. Dr. 2014/163a, C18, caroul 3b-d (G23). Pastă fină (arsă oxidant), de culoare Munsell 5YR7/4, cu particule de mică, oxizi rari (uneori sub formă de granule până la $2 \mathrm{~mm}$ ), particule de calcar rare. Modelare în tipar. Lut ars. $L p=6 \mathrm{~cm}, 1$ max. $=$ $5,11 \mathrm{~cm}, \mathrm{Gr}=0,66 \mathrm{~cm}$. Se păstrează o porțiune din torsul (?) unui personaj uman. $\mathrm{Nu}$ sunt redate elemente de decor ale îmbrăcămintei, pe față o proeminență care ar putea reprezenta o mână sub manta. Nr. inv. pr. 155.

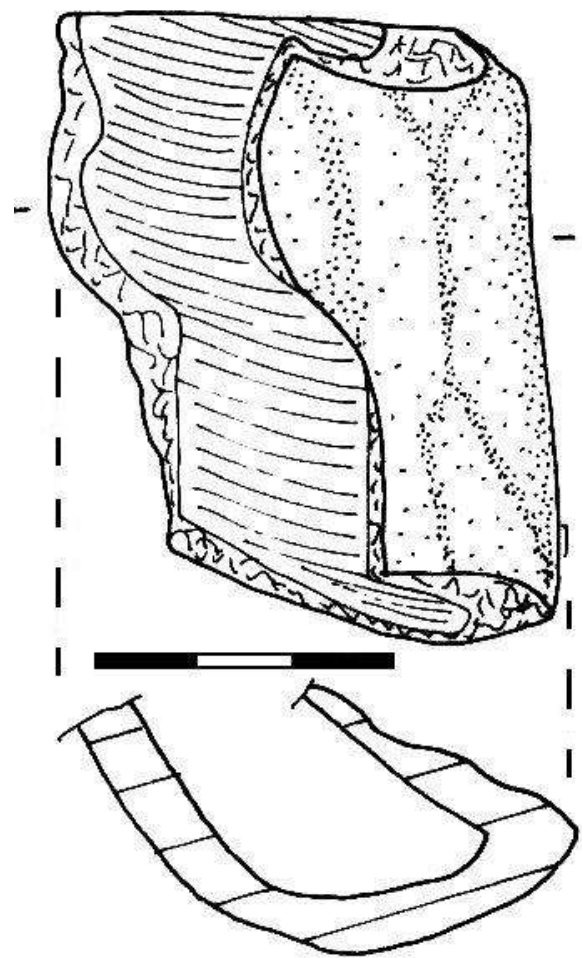

54. Statuetă (fragmentară). PI. VIII/54. Se păstrează un fragment din ambele valve. Dr. 2014/391a, C21a, -1,13-1,80 m. Pastă fină (arsă oxidant) de culoare Munsell 10YR8/4, cu particule de mică, oxizi relativ rari, particule de calcar rare. Modelare în tipar; surplus de material de la unirea celor două valve. Lut ars. $\mathrm{Lp}=5,20 \mathrm{~cm}, 1 \mathrm{p}=1,63$ $\mathrm{cm}, \mathrm{Gr}=0,57 \mathrm{~cm}$. Se păstrează un fragment dintr-o mână, respectiv fragmente din umăr, braț și antebraț. Aceasta este redată pe lângă corp acoperită de veșmânt. Nr. inv. pr. 156.

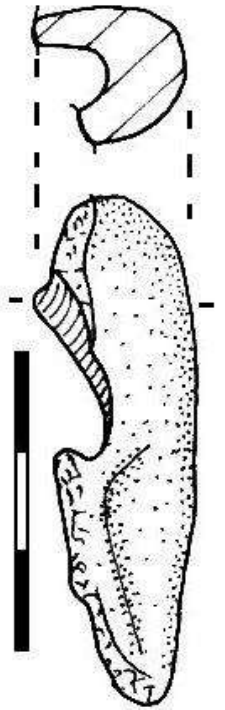

55. Statuetă (fragmentară). Pl. VIII/55. Se păstrează un fragment din ambele valve. Dr. 2014/148c, C18, G23, -2,54 m. Pastă fină (arsă oxidant) de culoare Munsell 10YR8/3, cu particule de mică, oxizi relativ rari, particule de calcar rare. Modelare în tipar. Lut ars. $\mathrm{Lp}=6,18 \mathrm{~cm}, \mathrm{lp}=2,13$ $\mathrm{cm}, \mathrm{Gr}=0,37 \mathrm{~cm}$. Se păstrează umărul, o parte din 
torace și brațul unei statuete. Două proeminențe, pot fi accidente în pasta crudă sau o redare a unui decor. Nr. inv. pr. 157.

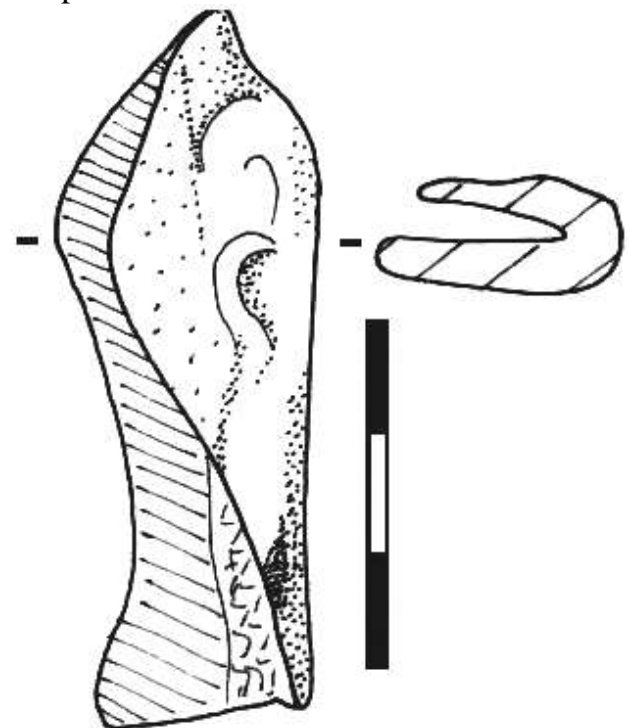

56. Statuetă (fragmentară). Pl. VIII/56. Se păstrează un fragment din valva anterioară. Dr. 2008/428, C17, carouri 7-8a-b, -1,15 m. Pastă fină (arsă oxidant) de culoare Munsell 5YR7/6, cu particule de mică, oxizi rari (uneori sub formă de granule), particule calcar rare, mici impurități și goluri. Modelare în tipar. Lut ars. $\mathrm{Lp}=5,57 \mathrm{~cm}$, lp $=3,40 \mathrm{~cm}, \mathrm{Gr}=0,90 \mathrm{~cm}$. Se păstrează jumătatea stânga a torsului și brațul stâng îndoit, al unei statuete (posibil Venus sau Eros). Nr. inv. pr. 158.

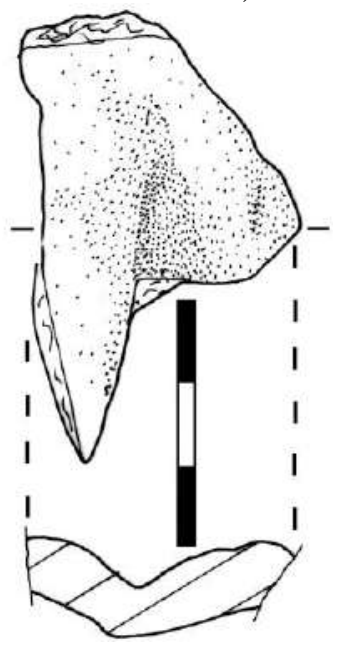

57. Statuetă (fragmentară). PI. VIII/57. Se păstrează un fragment din valva anterioară. Dr. 2012/129, C19, carouri 15-17a-d, -2,30-2,40 m. Pastă fină (arsă oxidant) de culoare Munsell 7.5YR6/6, cu particule de mică, cu oxizi relativ deși, particule de calcar relativ rare. Modelare în tipar. Lut ars. $\mathrm{Lp}=3,04 \mathrm{~cm}, \mathrm{lp}=2,78 \mathrm{~cm}, \mathrm{Gr}=$ $0,51 \mathrm{~cm}$. Se păstrează un fragment din abdomenul unui personaj cu redarea ombilicului printr-o impresiune. Nr. inv. pr. 159.

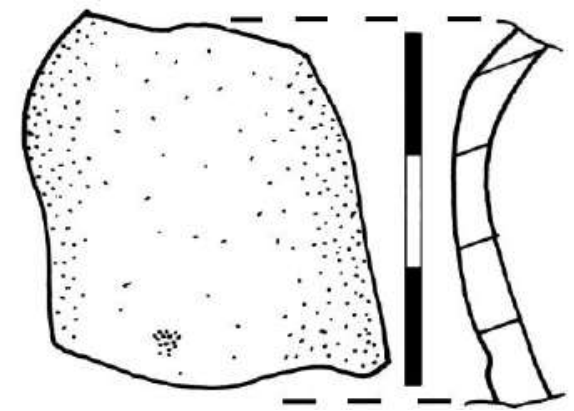

58. Statuetă (fragmentară). Pl. VIII/58. Se păstrează un fragment din valva posterioară. Dr. 2012/206, C22, carouri 1-2a-b, -1,10-1,13 m. Pastă fină (arsă reducător, neuniform) de culoare Munsell 7.5YR6/6, cu particule de mică, cu oxizi rari, particule de calcar relativ dese. Modelare în tipar (surplus de material pe interior). Lut ars. Lp = $4,28 \mathrm{~cm}, \mathrm{lp}=3,36 \mathrm{~cm}, \mathrm{Gr}=0,90 \mathrm{~cm}$. Se păstrează jumătatea dreaptă a spatelui unei statuete umane. Nr. inv. pr. 160.

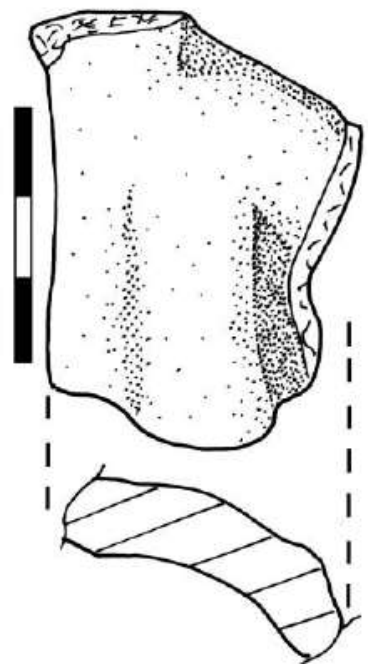

59. StAtuetă (fragmentară). Pl. VIII/59. Se păstrează un fragment din valva posterioară. Dr. 2013/241, C21b, carouri 10-13a-d, -1,79 m. Pastă fină (arsă oxidant) de culoare Munsell 2.5YR6/8, cu particule de mică, oxizi rari, particule de calcar rare. Modelare în tipar (surplus de material la interior; urme de amprente digitale în interior). Lut ars. $\mathrm{Lp}=5,52$ $\mathrm{cm}, \mathrm{lp}=4,85 \mathrm{~cm}, \mathrm{Gr}=0,83 \mathrm{~cm}$. Se păstrează un fragment din spatele unei statuete feminine?, acesta prezintă un orificiu, din fabricare, de formă circulară (fragmentar), pentru ventilație. Nr. inv. pr. 161.

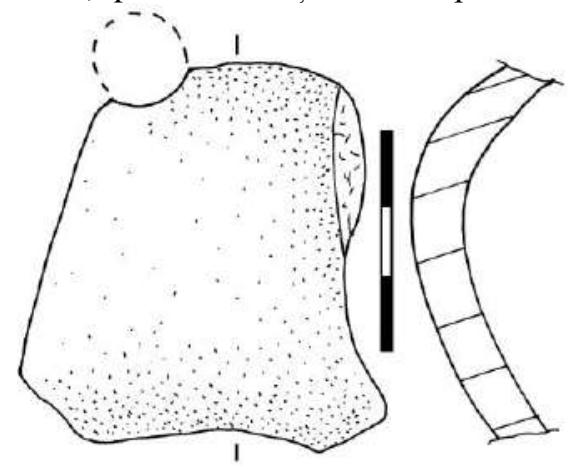


60. Statuetă (fragmentară). Pl. $\quad$ IX/60. Se păstrează un fragment din valva posterioară. Dr. 2013/204, C22a, carouri 1-4a-d, -1,70 m. Pastă fină (arsă oxidant, neuniform) de culoare Munsell 7.5YR6/6, cu particule de mică, oxizi relativ rari, particule de calcar rare. Modelare în tipar (urme de amprente digitale la interior). Lut ars. $\mathrm{Lp}=3,36$ $\mathrm{cm}, \mathrm{lp}=3,75 \mathrm{~cm}, \mathrm{Gr}=0,69 \mathrm{~cm}$. Fragmentul poate proveni de la spatele unei statuete umane. Nr. inv. pr. 162.

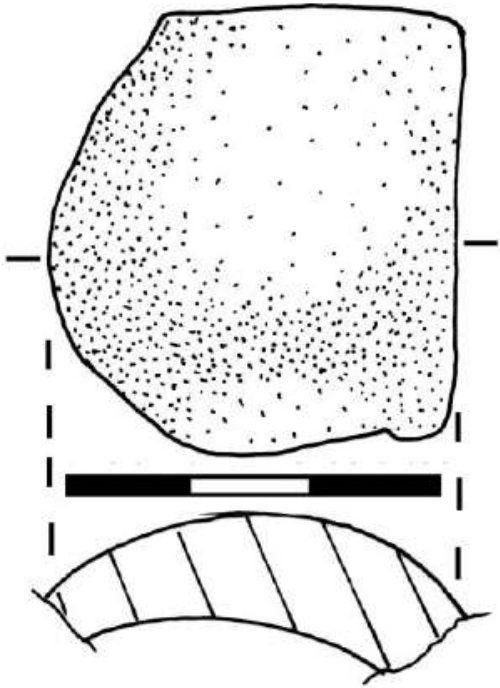

61. Statuetă (fragmentară). Pl. IX/61. Se păstrează un fragment din valva posterioară şi un mic fragment din cea anterioară. Dr. 2014/148b, C18, -2,54 m. Pastă fină (arsă oxidant) de culoare Munsell 7.5YR7/4, cu particule de mică, oxizi relativ rari, particule de calcar rare. Modelare în tipar (surplus de material de la unirea celor două valve). Lut ars. $\mathrm{Lp}=5,02 \mathrm{~cm}, \mathrm{lp}=4,27 \mathrm{~cm}, \mathrm{Gr}=$ $0,70 \mathrm{~cm}$. Fragmentul poate proveni de la spatele unei statuete umane. Nr. inv. pr. 163.

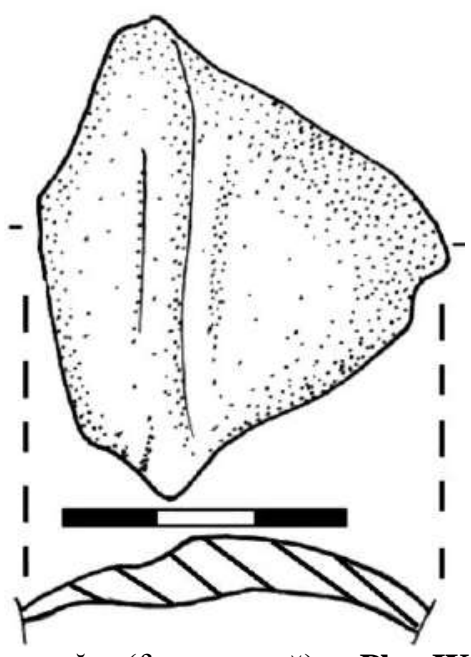

62. StAtUetă (fragmentară). Pl. IX/62. Se păstrează un fragment din ambele valve. Dr. 2016/212, C23, caroul 11e, $-1,72$ m. Pastă fină (arsă oxidant) de culoare Munsell 5YR7/6, cu particule de mică, oxizi relativ rari, particule de calcar rare. Modelare în tipar (urme de la retușarea cu un obiect ascuțit în pasta crudă, mai ales în zona de lipire a celor două valve, la exterior). Lut ars. Lp $=6,26 \mathrm{~cm}, \mathrm{lp}=2,13 \mathrm{~cm}, \mathrm{Gr}=1,43 \mathrm{~cm}$. Se păstrează un fragment din antebrațul și palma unei statuete umane. Degetele sunt redate doar pe partea interioară a palmei, iar extremitatea lui pollex este spartă. Nr. inv. pr. 164.
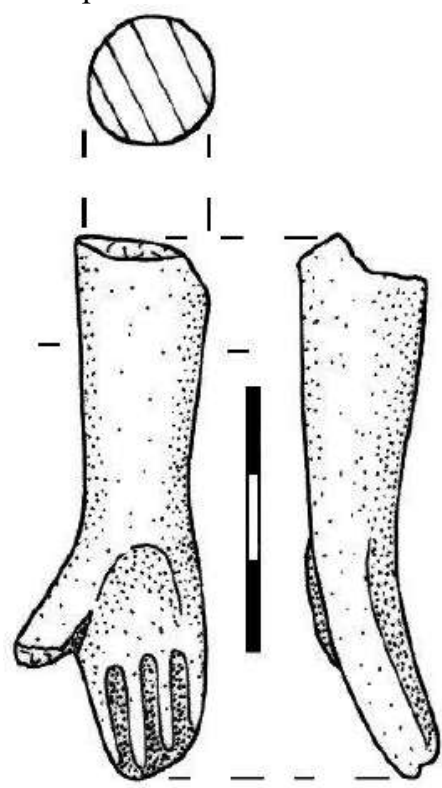

63. Statuetă (fragmentară). Pl. IX/63. Dr. 2014/148d, C18, G23, -2,54 m. Pastă fină (arsă oxidant, neuniform) de culoare Munsell 5YR7/4, cu particule de mică, oxizi relativ rari, particule de calcar rare; angobă de culoare Munsell 10YR8/2. Modelare în tipar (urme de amprente digitale). Lut ars. $\mathrm{Lp}=8,11 \mathrm{~cm}, \mathrm{Gr}=1,60 \mathrm{~cm}$. Se păstrează mâna dreaptă și un mic fragment din umărul unei statuete umane. Aceasta este redată îndoită din cot spre orizontală, iar palma este redată prelungă, fără a avea delimitate degetele, cu excepția lui pollex, care este redat lipit de palmă, dar cu vârful retezat. În zona cotului și a antebrațului este o cantitate mai mare de material, ceea ce indică existența în această zonă fie a unei mantii, fie a unui părți din corp. Nr. inv. pr. 165

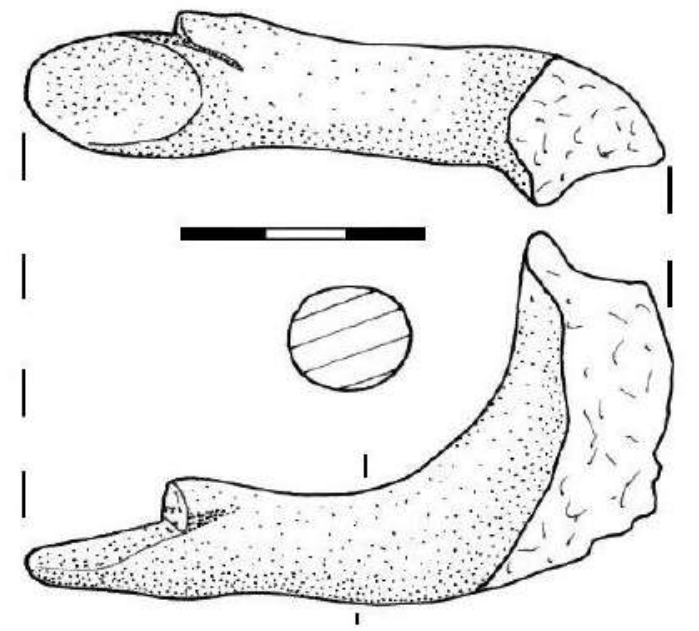

64. Statuetă (fragmentară). Pl. IX/64. Se păstrează un fragment din brațul drept. Dr. 
2014/48c, C18, carouri 3a-b, G23, -2,05 m. Pastă fină (arsă oxidant) de culoare Munsell 10YR7/4, cu particule de mică, oxizi relativ rari, particule de calcar rare; mici fisuri. Lut ars. Modelare în tipar (urme de amprente digitale). $\mathrm{Lp}=5,21 \mathrm{~cm}, \mathrm{lp}=$ $2,17 \mathrm{~cm}, \mathrm{Gr}=2,06 \mathrm{~cm}$. Se păstrează mâna dreaptă a unei statuete umane. Aceasta este redată pe lângă corp, păstrându-se și un mic fragment din umăr și corp, fiind îndoită din cot spre orizontală. Palma este prelungă, degetele nu sunt redate, exceptând pollex, care este redat lipit de palmă. Vârful palmei și a lui pollex sunt rupte. Nr. inv. pr. 166.

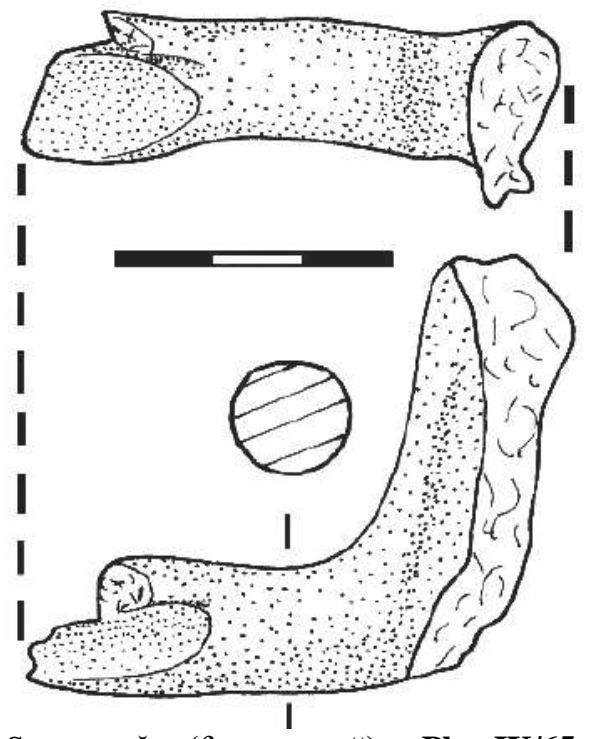

65. Statuetă (fragmentară). Pl. IX/65. Se păstrează un fragment din antebraț. Dr. 2014/122, C18, 3b-d (G23), -2,38 m. Pastă fină (arsă oxidant, neuniform) de culoare Munsell 7.5YR7/4, cu particule de mică, oxizi relativ deși, particule de calcar rare. Modelare; mici retuşuri; urme de amprente digitale. Lut ars. $\mathrm{Lp}=5,90 \mathrm{~cm}, \mathrm{lp}=1,80$ $\mathrm{cm}, \mathrm{Gr}=1,29 \mathrm{~cm}$. Se păstrează un fragment din antebrațul și palma dreaptă a unei statuete umane. Degetele nu sunt delimitate, exceptând pollex, care este redat lipit de palmă, dar cu vârful retezat. Palma este prelungă, antebrațul gros. Nr. inv. pr. 167.

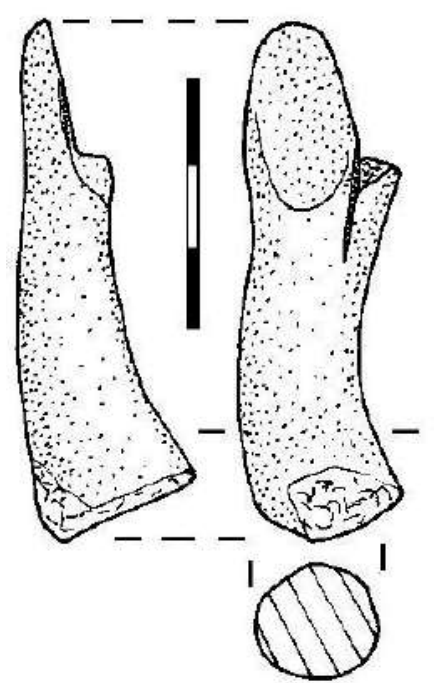

66. Statuetă (fragmentară). Pl. IX/66. Dr. 2014/60, C18, carouri 3a-b, G23, -2,15 m. Pastă fină (arsă oxidant) de culoare Munsell 7.5YR7/4, cu particule de mică, oxizi relativ rari, particule de calcar rare. Modelare (urme de amprente digitale). Lut ars. $\mathrm{Lp}=4,86 \mathrm{~cm}, \mathrm{lp}=1,44 \mathrm{~cm}, \mathrm{Gr}=1,28 \mathrm{~cm}$. Se păstrează un fragment din antebrațul și palma dreaptă a unei statuete umane. Degetele nu sunt redate, exceptând pollex, care este gros și lipit de palmă, dar cu vârful retezat. Nr. inv. pr. 168.

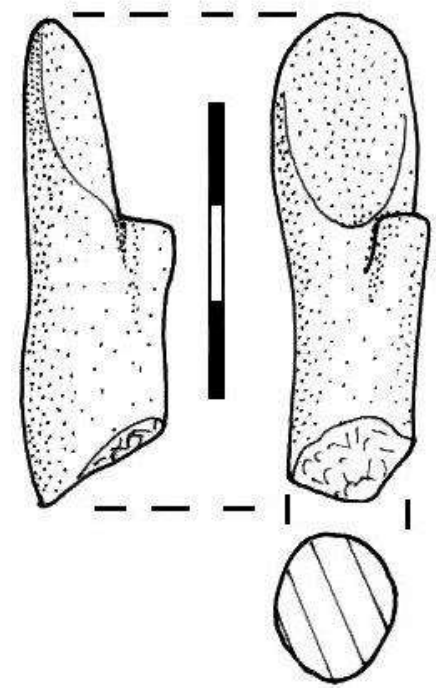

67. Statuetă (fragmentară). PI. IX/67. Dr. 2010/125, C19, carouri 10-13a-b, $-1,50-1,55 \mathrm{~m}$. Pastă fină (arsă oxidant) de culoare Munsell 10 YR8/3, cu particule de mică, rar oxizi, particule de calcar rare. Modelare (surplus de material pe alocuri, grosolan prelucrat pe antebrat;; urme de amprente digitale). Lut ars. $\mathrm{Lp}=5,10 \mathrm{~cm}, \mathrm{Gr}=1,36$ $\mathrm{cm}$. Se păstrează o parte din palma și antebrațul unei statuete umane. Pollex este redat grosolan, ușor delimitat de palmă și cu vârful retezat. Nr. inv. pr. 169.

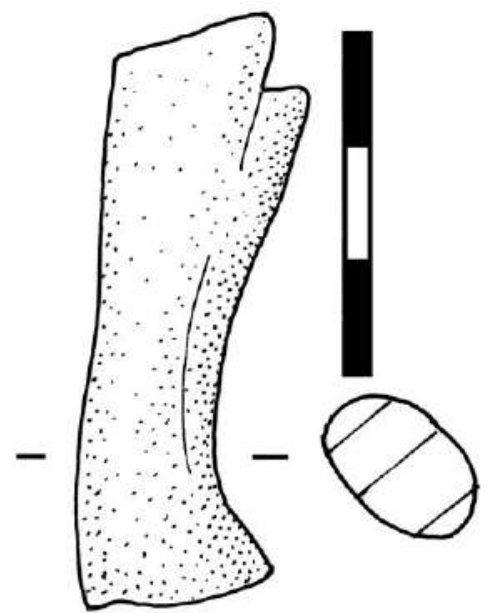

Analogii nr. 63-68: Ostrov statuetă (lut): Bâltâc, Ştirbulescu 2007-2008, 176-177, nr. 28, pl. 9/28. 
68. Statuetă (fragmentară). Pl. IX/68. Dr. 2010/123, C19, carouri 12-17c-d, $-1,40$ m. Pastă fină (arsă oxidant) de culoare Munsell 10YR8/3, cu particule de mică, oxizi rari, particule de calcar rare. Modelare (urme de retuşare). Lut ars. Lp = $5,51 \mathrm{~cm}, \mathrm{lp}=1,56 \mathrm{~cm}, \mathrm{Gr}=1,32 \mathrm{~cm}$. Se păstrează palma și o parte din antebrațul unei statuete umane. Degetele nu sunt redate, cu excepția lui pollex, care este redat grosolan, lipit de palmă și cu vârful ușor retezat. În palmă o bucată de lut, foarte neglijent lucrată, de formă semicirculară, reprezintă un obiect dificil de identificat. Nr. inv. pr. 170.

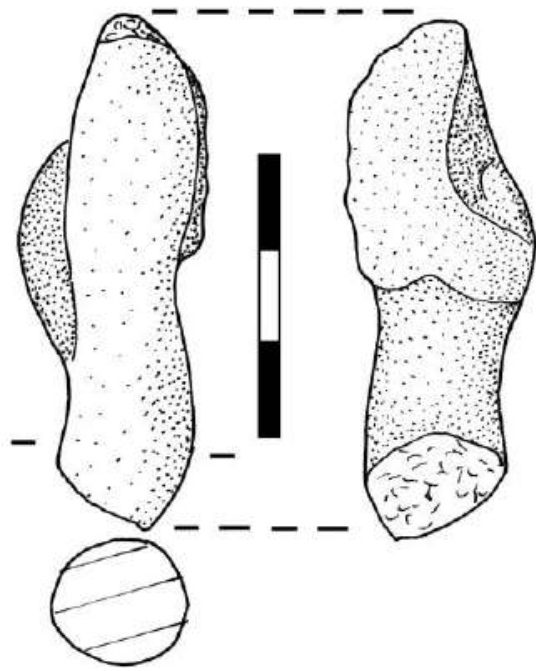

69. Statuetă (fragmentară). Pl. IX/69. Dr. 2013/220, C21a-22a (demontare martor). Pastă fină (arsă oxidant, neuniform) de culoare Munsell 2.5YR7/8, cu particule de mică, particule de calcar rare. Modelare. Lut ars. $\mathrm{Lp}=4,66 \mathrm{~cm}, \mathrm{Gr}=0,11$ cm. Se păstrează un fragment din umărul și antebrațul drept al unei statuete umane. Nr. inv. pr. 171.

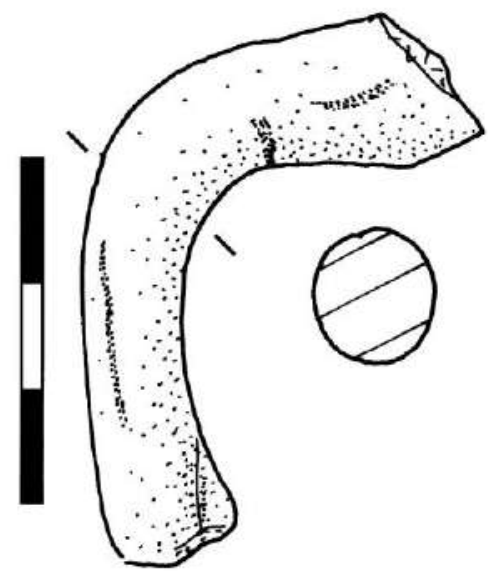

70. Statuetă (fragmentară). Pl. X/70. Dr. 2012/197, C21, carouri 9-17a-b, -1,62-1,67 m. Pastă semifină (arsă oxidant) de culoare Munsell 5YR7/6, cu particule de mică, oxizi relativ rari, particule calcar sub formă de granule (de până la 5 $\mathrm{mm})$. Modelare. Lut ars. $\mathrm{Lp}=3,04 \mathrm{~cm}, \mathrm{Gr}=0,15$ $\mathrm{cm}$. Se păstrează un mic fragment din brațul unei statuete umane. Nr. inv. pr. 172.

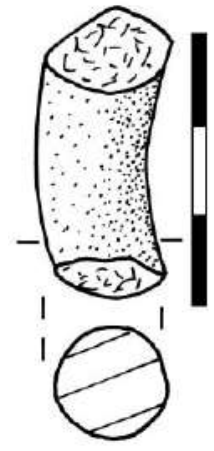

71. Statuetă (fragmentară). Pl. X/71. Dr. 2013/226, C23a, carouri 1-4a-f, $-1,15 \mathrm{~m}$. Lp = $2,38 \mathrm{~cm}, 1=1,62 \mathrm{~cm}, \mathrm{Gr}=0,10 \mathrm{~cm}$. Pastă fină $($ arsă oxidant, neuniform) de culoare Munsell 7.5YR8/4, cu particule de mică, oxizi rari, particule de calcar rare, mici crăpături și fisuri. Modelare. Lut ars. Lp $=2,38 \mathrm{~cm}, 1=1,62 \mathrm{~cm}, \mathrm{Gr}=0,10 \mathrm{~cm}$. Se păstrează un mic fragment din antebraț, zona umărului, de la o statuetă umană. Nr. inv. pr. 173.

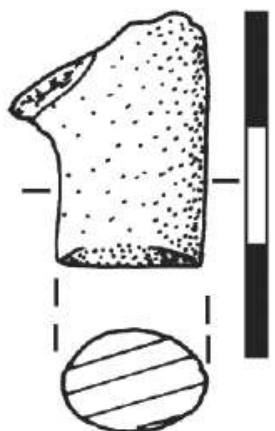

72. StATUETĂ (fragmentară). PI. X/72. Se păstrează un fragment dintr-o valvă. Dr. 2012/170, C22, carouri $9-17 \mathrm{a}-\mathrm{d},-1,34 \mathrm{~m}$. Pastă fină (arsă oxidant) de culoare Munsell 5YR7/4, cu particule de mică, oxizi relativ rari, particule de calcar rare. Modelare în tipar. Lut ars. $\mathrm{Lp}=3,80 \mathrm{~cm}, 1=1,55 \mathrm{~cm}, \mathrm{Gr}=$ $0,94 \mathrm{~cm}$. Se păstrează un fragment dintr-un braț detașabil al unei statuete. Îmbinarea cu celelalte părți componente se realiza prin prinderea printr-un orificiu circular realizat în pasta crudă. Nr. inv. pr. 174. Analogii: Nicopolis ad Istrum, statuetă (lut): Falkner 2007, 91, nr. 6.16.

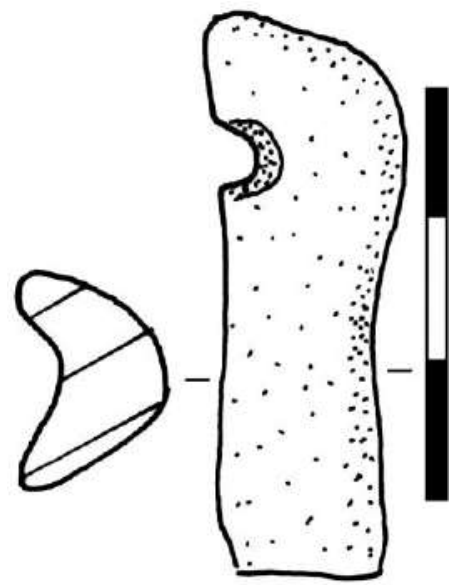


73. Statuetă (fragmentară). Pl. X/73. Dr. 2010/226, C19, carouri 11-13a-b, $-1,50-1,55 \mathrm{~m}$. Pastă caolinoasă, cu particule de mică. Urme de vopsea de culoare Munsell 7.5YR9.5/1. Modelare (pe spate diverse crăpături de la suprafața pe care sa făcut modelarea). Lut ars. $\mathrm{Lp}=4,97 \mathrm{~cm}, \mathrm{lp}=6,17$ $\mathrm{cm}, \mathrm{Gr}=1,76 \mathrm{~cm}$. Se păstrează suprafața plantară a piciorului drept al unei statui, cel mai probabil masculină. Degetele sunt modelate cu un obiect ascuțit în pasta crudă, unghiile sunt marcate. Degetul mare lipsă. Nr. inv. pr. 175.

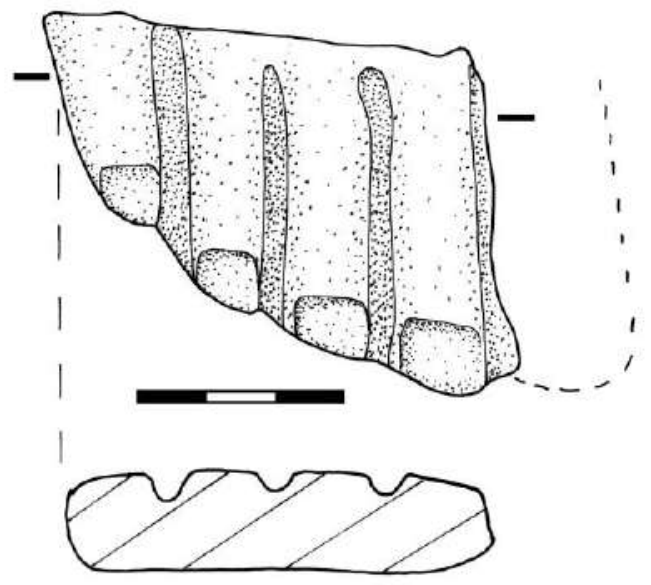

74. StAtuetă (fragmentară). PI. X/74. Se păstrează un fragment din ambele valve. Dr. 2014/007a, demontare martor C18-19. Pastă fină (arsă oxidant) de culoare Munsell 2.5YR8/3, cu particule de mică, oxizi relativ rari, particule de calcar rare. Modelare (urme de retuș cu un obiect ascuțit). Lut ars. Lp = 5 $\mathrm{cm}, \mathrm{lp}=2,5 \mathrm{~cm}, \mathrm{Gr}=1 \mathrm{~cm}$. Se păstrează partea inferioară a gambei și suprafața plantară a piciorului drept dintr-o statuetă masculină. Talpa este foarte lungă, iar degetele sunt redate foarte slab. Pe gambă se mai păstrează o parte a piciorului stâng. Nr. inv. pr. 176.

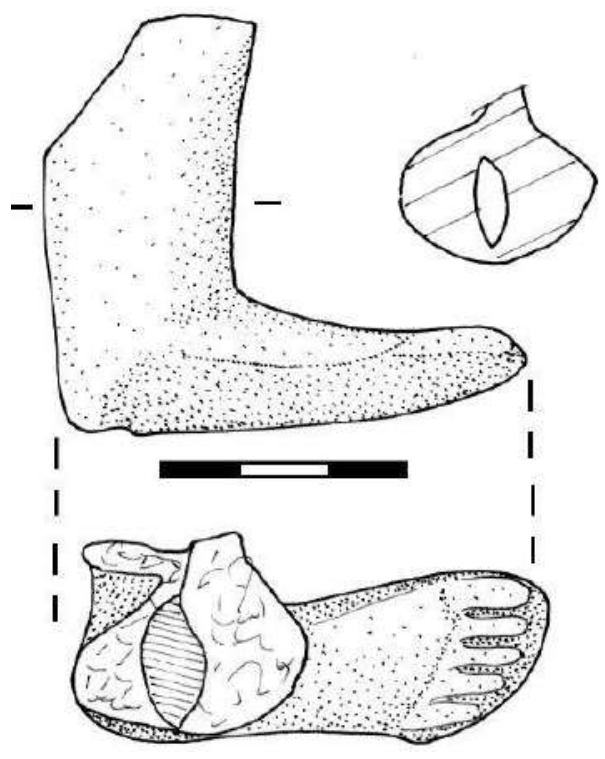

75. Statuetă (fragmentară). Pl. X/75. Bivalv. Dr. 2016/89, C23, caroul 9d, -1,54 m. Pastă fină (arsă oxidant), de culoare Munsell 7.5YR8/6 cu particule de mică, oxizi rari, particule de calcar rare. Modelare în tipar (surplus de material pe talpă, retuşat la modelare). Lut ars. $\mathrm{Lp}=3,91 \mathrm{~cm}, \mathrm{lp}=$ $2,29 \mathrm{~cm}, \mathrm{Gr}=0,78 \mathrm{~cm}$. Se păstrează suprafața plantară a piciorului stâng a unei statuete umane. Degetele sunt redate foarte slab, se păstrează un mic fragment de la îmbinarea cu piciorul drept. Nr. inv. pr. 178 .

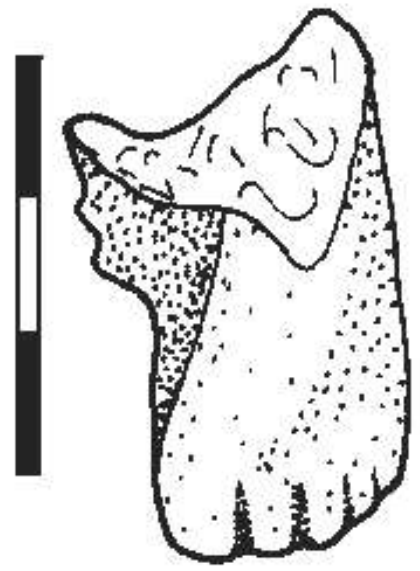

76. Statuetă (fragmentară). PI. X/76. Bivalv. Dr. 2010/238, C19, carouri 14-17c-d, -1,61-1,65 m. Pastă fină (arsă oxidant) de culoare Munsell 7.5YR6/6, cu particule de mică, oxizi rari, particule mari de calcar. Modelare în tipar (mici incizii accidentale în pasta crudă). Lut ars. $\mathrm{Lp}=3,44 \mathrm{~cm}$, $\mathrm{lp}=2,66 \mathrm{~cm}, \mathrm{Gr}=1,06 \mathrm{~cm}$. Se păstrează suprafaţa plantară a piciorului stâng și talpa piciorului drept ale unei statuete umane. Sunt redate degetele, deși foarte slab vizibile. Nr. inv. pr. 179.

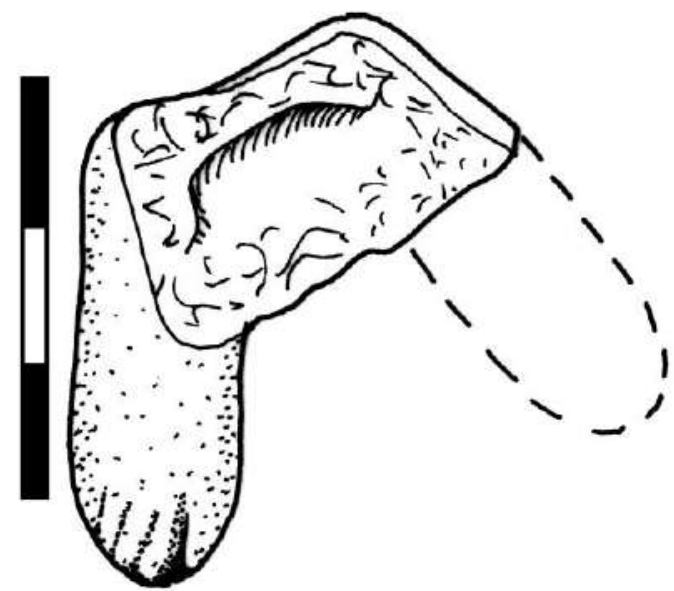

77. StAtuetĂ (fragmentară). PI. X/77. Se păstrează un fragment din ambele valve. Dr. 2014/134d, C18, carouri 3b-d, $-2,54$ m. Pastă fină (arsă oxidant, neuniformă) de culoare Munsell 2.5YR7/6, cu particule de mică, oxizi relativ rari, particule calcar rare. Modelare în tipar (urme de la retușare cu un obiect ascuțit). Lut ars. $\mathrm{Lp}=4,70 \mathrm{~cm}, \mathrm{lp}=1,72 \mathrm{~cm}$, $\mathrm{Gr}=1,17-1,57 \mathrm{~cm}$. Se păstrează un fragment din gamba și suprafața plantară a piciorului drept a unei 
statuete masculine. Personajul poartă încălțăminte înaltă, redată în partea superioară prin două muluri. Pe gambă se mai păstrează un alt mic fragment, probabil dintr-un accesoriu (sau aripă?). Nr. inv. pr. 177.

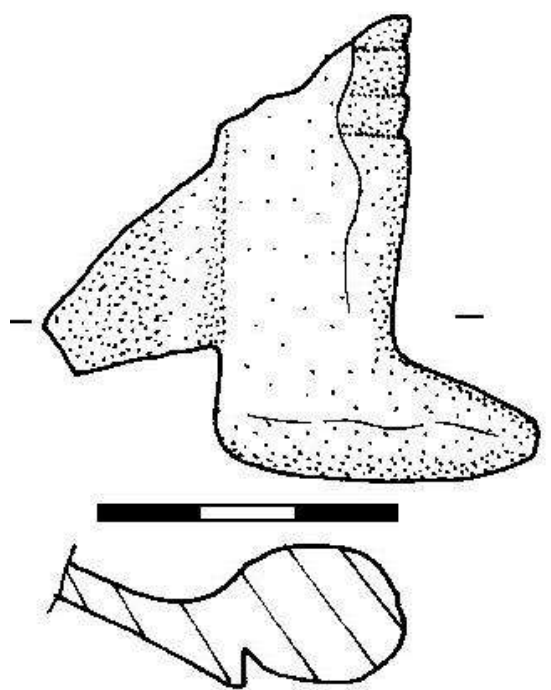

78. StAtUetă (fragmentară). Pl. X/78. Se păstrează fragmente din ambele valve. Dr. 2013/32, C22a, carouri 1-5d, $-1,46$ m. Pastă fină (arsă oxidant) de culoare Munsell 10YR8/4, cu particule de mică, oxizi sub formă de granule (de $2-3 \mathrm{~mm}$ ), particule de calcar rare. Modelare în tipar (surplus de material în interior de la unirea valvelor; urme de la amprentele digitale). Lut ars. $\mathrm{Lp}=4,46 \mathrm{~cm}, \mathrm{lp}=$ $2,02 \mathrm{~cm}, \mathrm{Gr}=0,73 \mathrm{~cm}$. Se păstrează o parte dintr-o gambă și suprafața plantară a piciorului stâng dintro statuetă umană. Lipsește o parte din călcâi și din laba piciorului din fabricație, iar degetele nu sunt reprezentate. Laba piciorului este foarte mică în comparație cu gamba, iar pe gambă se mai păstrează un fragment fie din piciorul drept, fie de la un accesoriu. Nr. inv. pr. 180.

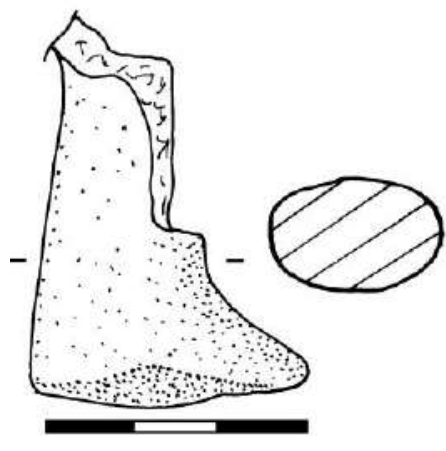

79. StAtuetă (fragmentară). PI. X/79. Se păstrează ambele valve. Dr. 2014/129, C22, carouri 1b-d, 1,94-2,22 m. Pastă fină (arsă oxidant) de culoare Munsell 5YR7/6, cu particule de mică, oxizi relativ rari, particule de calcar rare. Modelare în tipar (urme de la retuşarea cu un obiect ascuțit în pasta crudă). Lut ars. $\mathrm{Lp}=9,09 \mathrm{~cm}, 1=3,35 \mathrm{~cm}, \mathrm{Gr}=$ $0,57 \mathrm{~cm}$. Se păstrează cea mai mare parte a unui picior detașabil dintr-o statuetă. Vârful suprafeței plantare este spart, iar trecerea de la călcâi la picior este redată neanatomic. Îmbinarea cu celelalte părți componente se realiza printr-un orificiu circular realizat în pasta crudă. Nr. inv. pr. 181. Analogii: Ostrov, statuetă (lut): Muşeţeanu, Elefterescu 1988-1989, fig. 5.

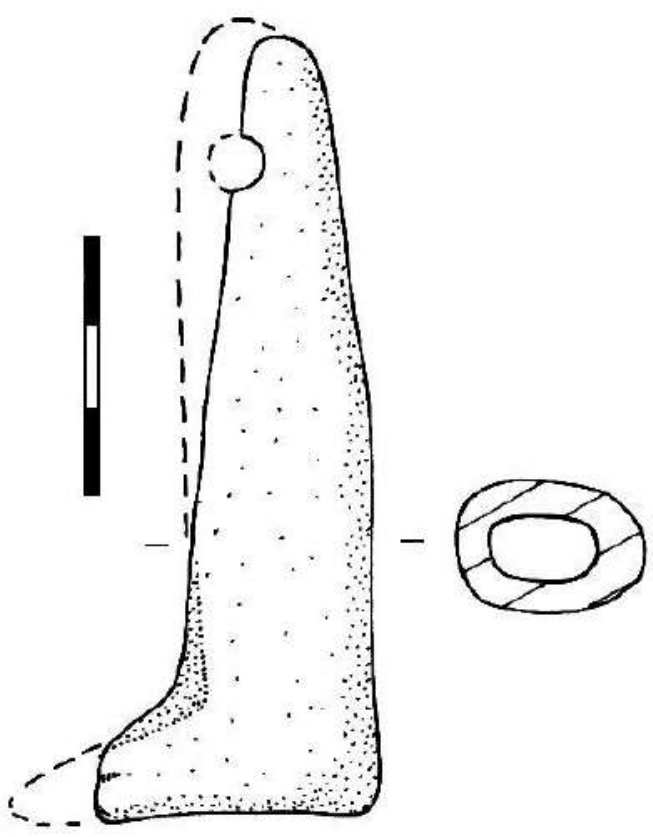

BIBLIOGRAFIE

Bâltâc, Știrbulescu 2007-2008

Bâltâc, Știrbulescu 2010
A. Bâltâc, C. Știrbulescu, Teracote din așezarea civilă romană de la Ostrov (Durostorum), jud. Constanța (I), CA, XIV-XV, 2007-2008, p. 167-202

A. Bâltâc, C. Știrbulescu, Teracote din așezarea civilă romană de la Ostrov (Durostorum), jud. Constanţa (II), CA, XVII, 2010, p. 55-70 
Bâltâc et alii 2015

\section{CCET I}

CCET II/1

\section{CCET II/2}

\section{CCET IV}

DA III/2

DA IV/1

Dragomir 1996

Falkner 2007

\section{LIMC VIII/1}

\section{LIMC VI/1}

Cholakov 2008

Man 2011

Milčev 1959

Munsell 2013

Mușețeanu, Elefterescu 1985a

Muşeţeanu, Elefterescu 1985b

Mușețeanu,

Elefterescu 1988-1989

Scorpan 1967

Țeposu-Marinescu 1982

Vladkova 2012
A. Bâltâc, C. Știrbulescu, A.Ștefan, V. Apostol, Muzeul Național de Istorie a României, Catalogul Colecției Lapidarium. I. Piese greco-romane, București, 2015

Z. Gočeva, M. Oppermann, Corpus Cultus Equitis Thracii, I. Monumenta orae Ponti Euxini Bulgariae, Leiden, 1979

Z. Gočeva, M. Oppermann, Corpus Cultus Equitis Thracii, II. Monumenta inter Danubium et Haemum reperta, fas. 1. Durostorum et vicinia, regio oppidi Tolbuhin, Marcianopolis et vicinia, regio opipidi Šumen, Leiden, 1981 Z. Gočeva, M. Oppermann, Corpus Cultus Equitis Thracii, II. Monumenta inter Danubium et Haemum reperta, fac. 2. Regio oppidi Targovište, Abritus et vicinia, Sexaginta Prista et vicinia, Nicopolis ad Istrum et vicinia, Novae, Leiden, 1984

N. Hamparţumian, Corpus Cultus Equitis Thracii, IV. Moesia Inferior (Romanian Section) et Dacia, Leiden, 1979

Dictionnaire des Antiquités Grecques et Romaines, Ch. Daremberg, E. Saglio (eds.), vol. III/2, Paris, 1901, s.v. Lares, p. 937-949 (J.-A. Hild)

Dictionnaire des Antiquités Grecques et Romaines, Ch. Daremberg, E. Saglio (eds.), vol. IV/1, Paris, s.v. Penates, p. 376-381 (J.-A. Hild)

I. T. Dragomir, Continuitatea locuirii dacice în castrul de la Barboşi Galaţi, în Monografia arheologică a Moldovei de Sud, I, Danubius. Revista Muzeului de Istorie „Paul Păltănea”, Galați 16, 1996, p. 401-417

R. Falkner, Ceramic Objects, în A. Poulter, Nicopolis ad Istrum III: A Late Roman and Early Byzantine City: the Finds and the Biological Remains, Londra, 2007

Lexikon Iconographicum Mythologiae Classicae, Zürich-München, VIII/1, s.v. Venus, p. 192-230 (Evamaria Schmidt)

Lexikon Iconographicum Mythologiae Classicae, Zürich-München, VI/1, s.v. Lar, Lares, p. 205-212 (Tran Tam Tinh)

I. Cholakov, A Roman Production Centre for terracottas in Heraclea Sintica (Southwest Bulgaria), Archaeologia Bulgarica, Sofia, XII, 2008, 1, p. 55-76.

Coja 1974 M. Coja, Terres cuites d'époque hellénistique représentant le cavalier thrace, trouvées à Histria, Dacia, N.S., XVIII, 1974, p. 283-288

N. Man, Aşezarea romană de la Cristeşti, Cluj, 2011

A. Milčev, Săm kulta na trakiickiia konik v dolinata ha Sredna Struma, Arheologija Sofia, 1959, 1-2, p. 67-73

Munsell soil-color charts with genuine Munsell ${ }^{\mathrm{R}}$ color chips, 2009 year revised/2013 production

C. Muşeţeanu, D. Elefterescu, Contribuţii privind ceramica romană de la Durostorum, CCDJ, I, 1985, p. 67-81

C. Muşeţeanu, D. Elefterescu, Teracote de la Durostorum reprezentând-o pe Venus, Pontica, 18, 1985, p. 185-191

C. Muşeţeanu, D. Elefterescu, Contribuţii privind ceramica romană de la Durostorum (II), CCDJ, V-VII, 1988-1989, p. 89-119

C. Scorpan, Cavalerul trac, Muzeul regional de arheologie Dobrogea, Constanța, 1967

L. Teposu-Marinescu, Funerary Monuments in Dacia Superior and Dacia Porolissensis, BAR International Series 128, 1982

P. Vladkova, Terakoti ot anticinite proizvodstveni țentrove ot teritoriata na Nicopolis ad Istrum, Arheologija Sofia, 53, 2, 2012, p. 108-119

Desene: GEORGIANA DUCMAN

Fotografii: GEORGE NICA, ALEXANDRU OSMULIKEVICI

ADEla BÂltÂC, CHRISTINA ȘTIRBULESCU Muzeul Național de Istorie a României adela.baltac@gmail.com christina_stirbulescu@yahoo.com 


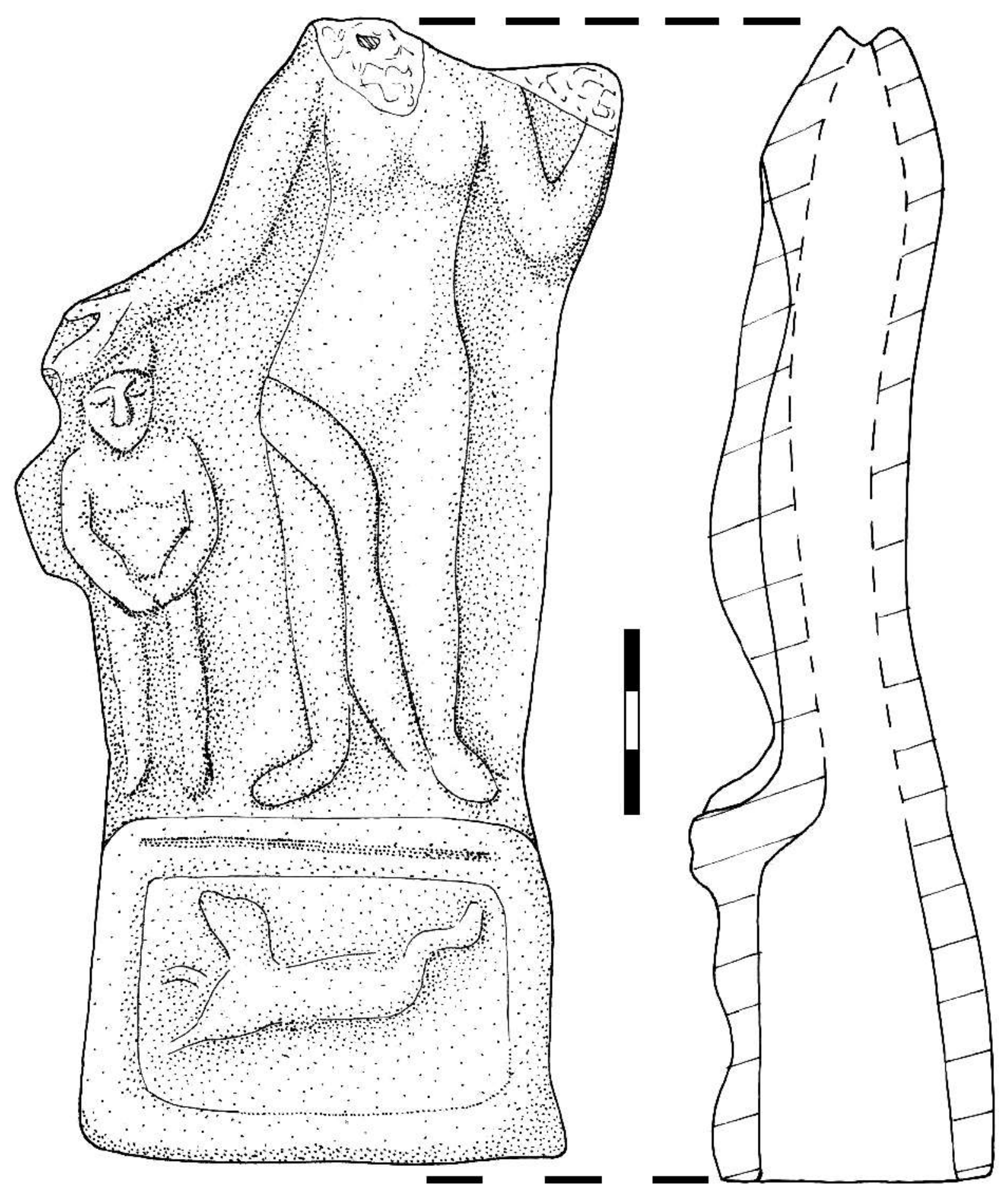

Nr. cat. 5 


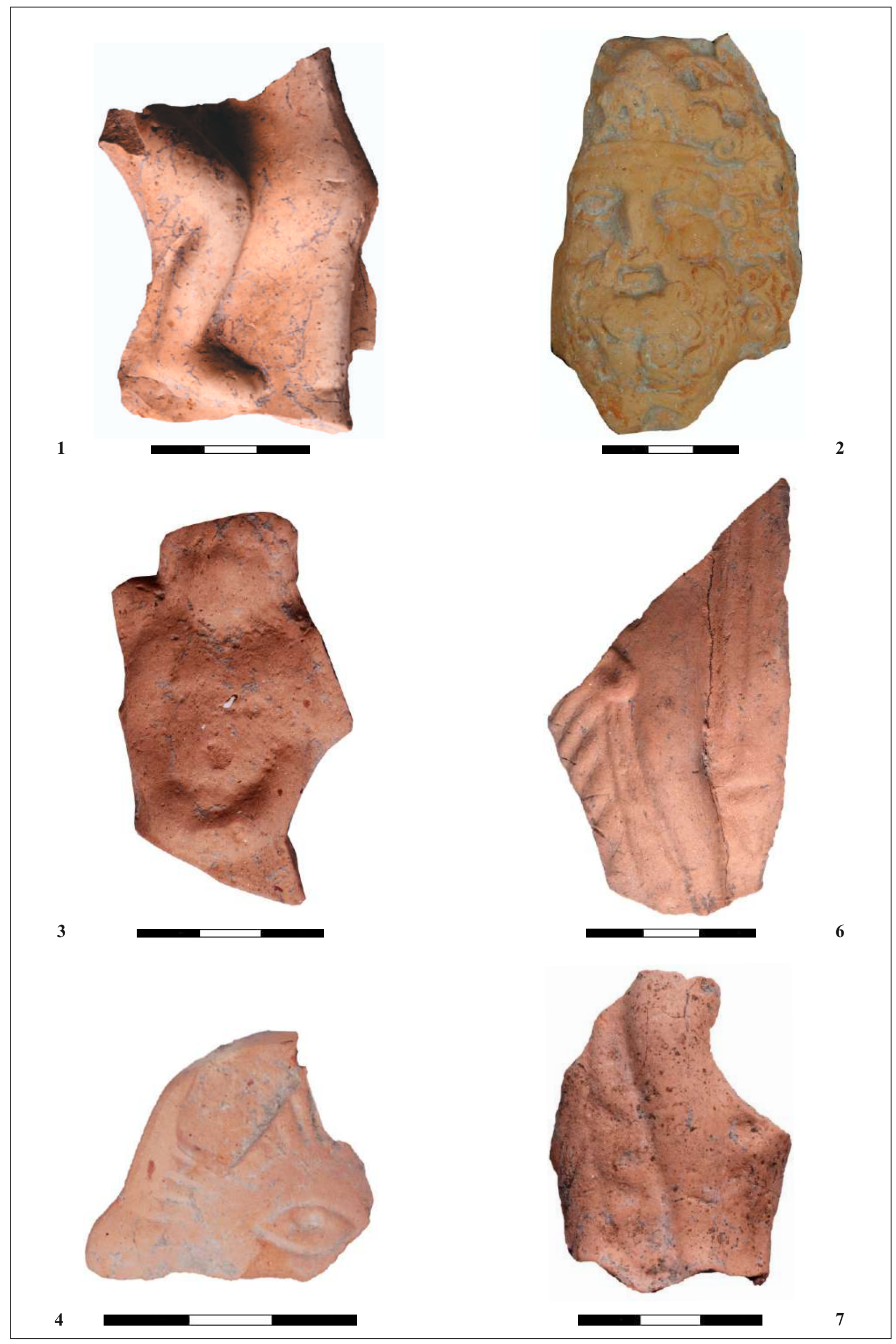

PI. I 



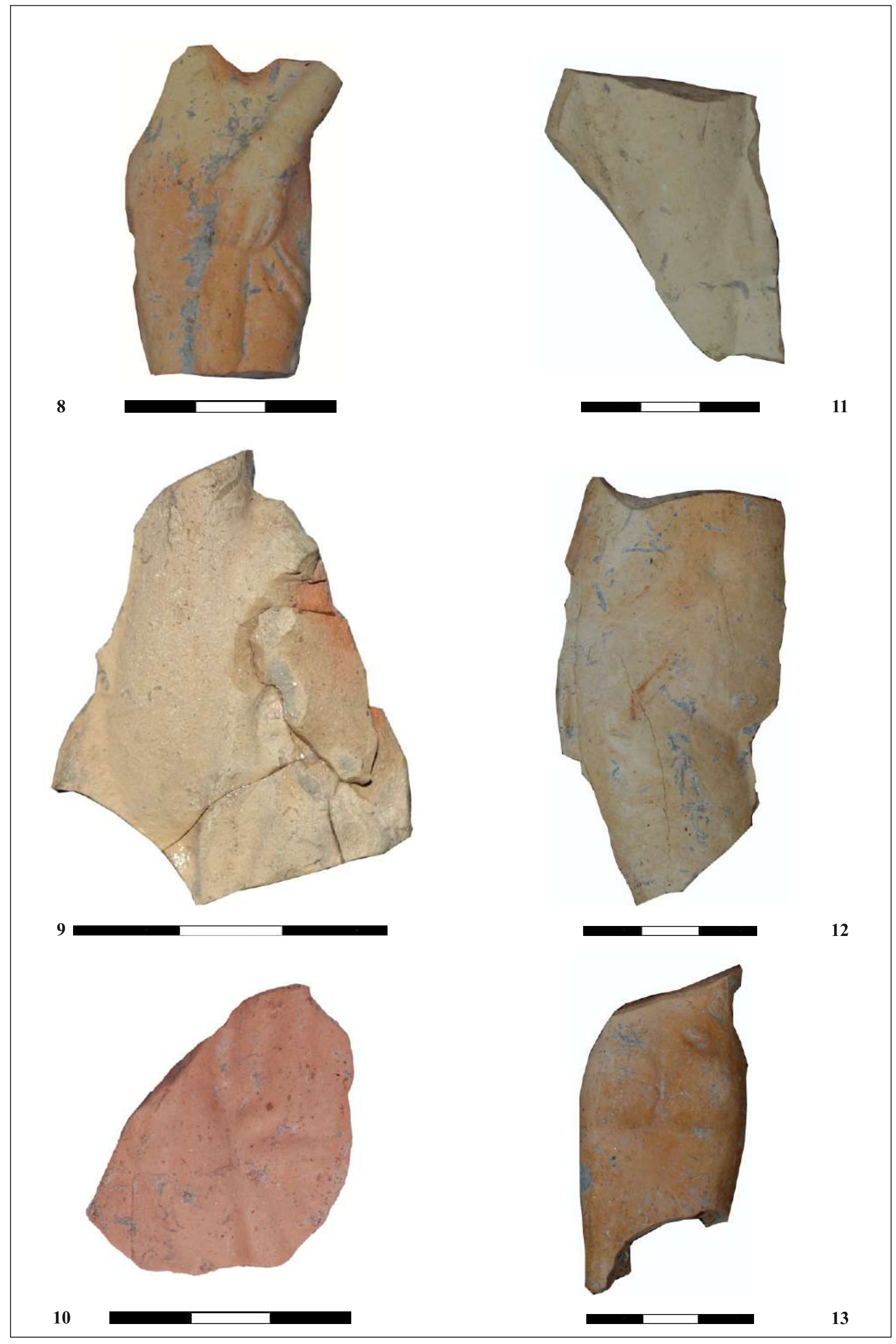

PI. III 


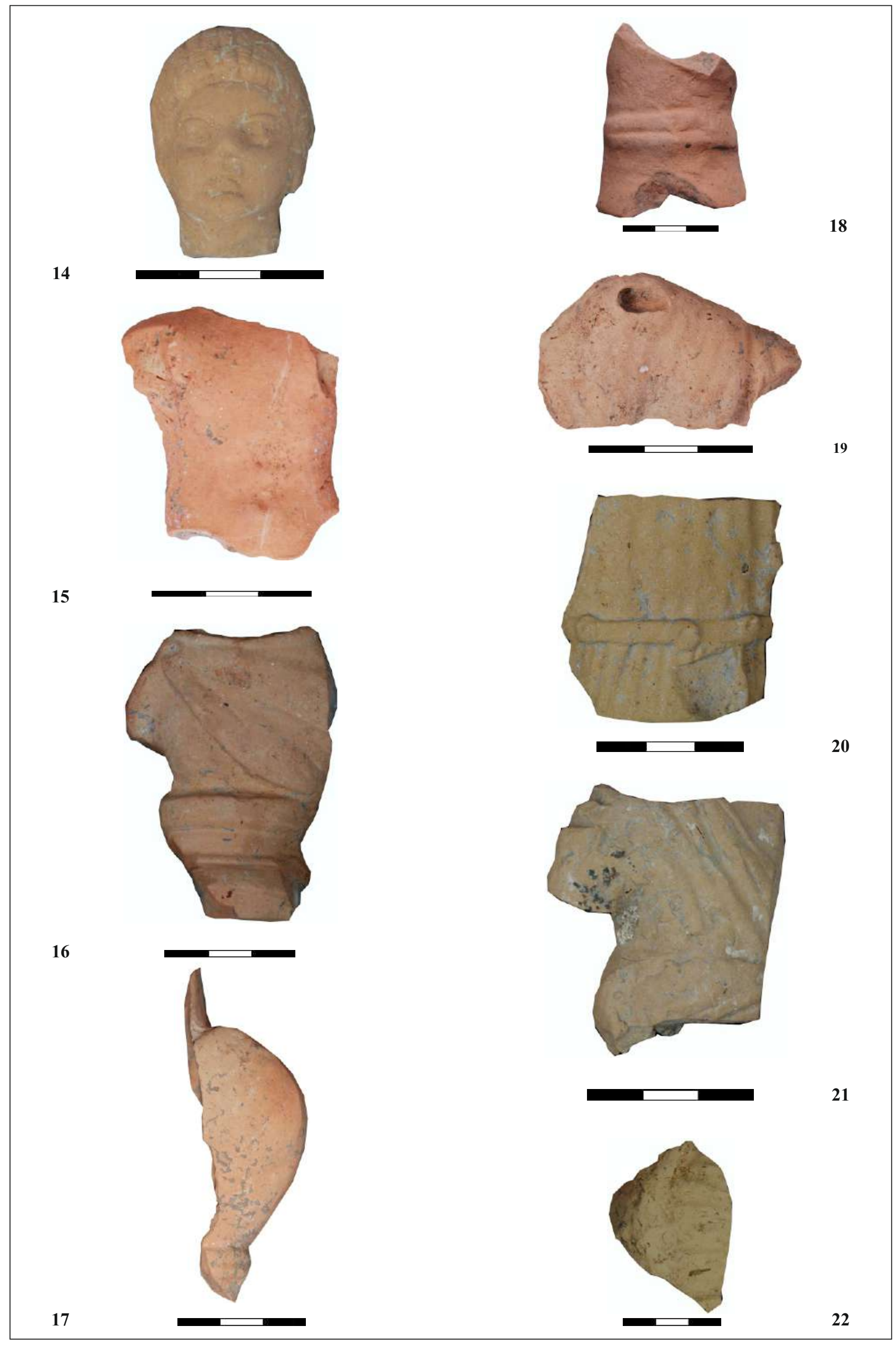

PI. IV 


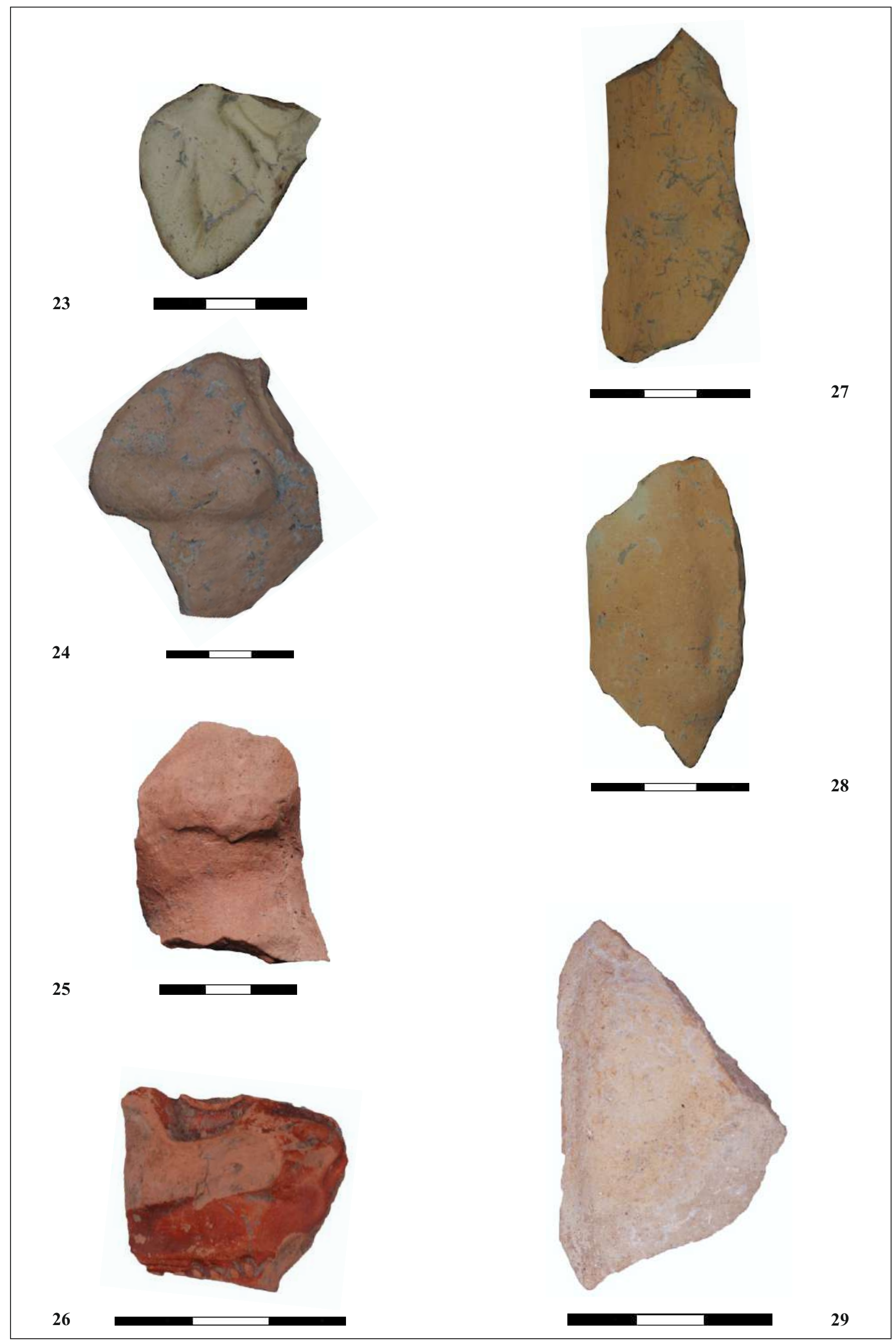

PI. V 


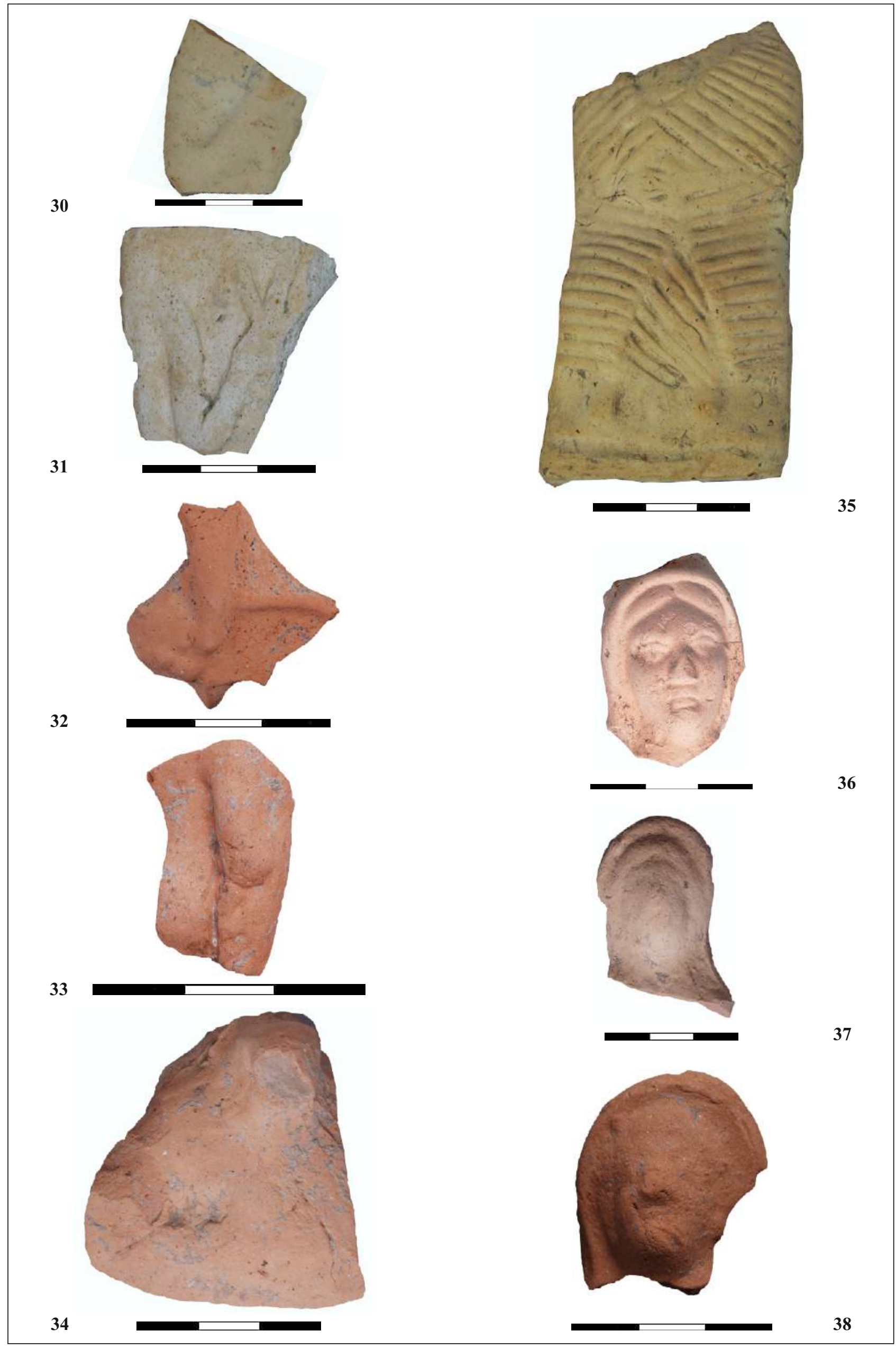

PI. VI 


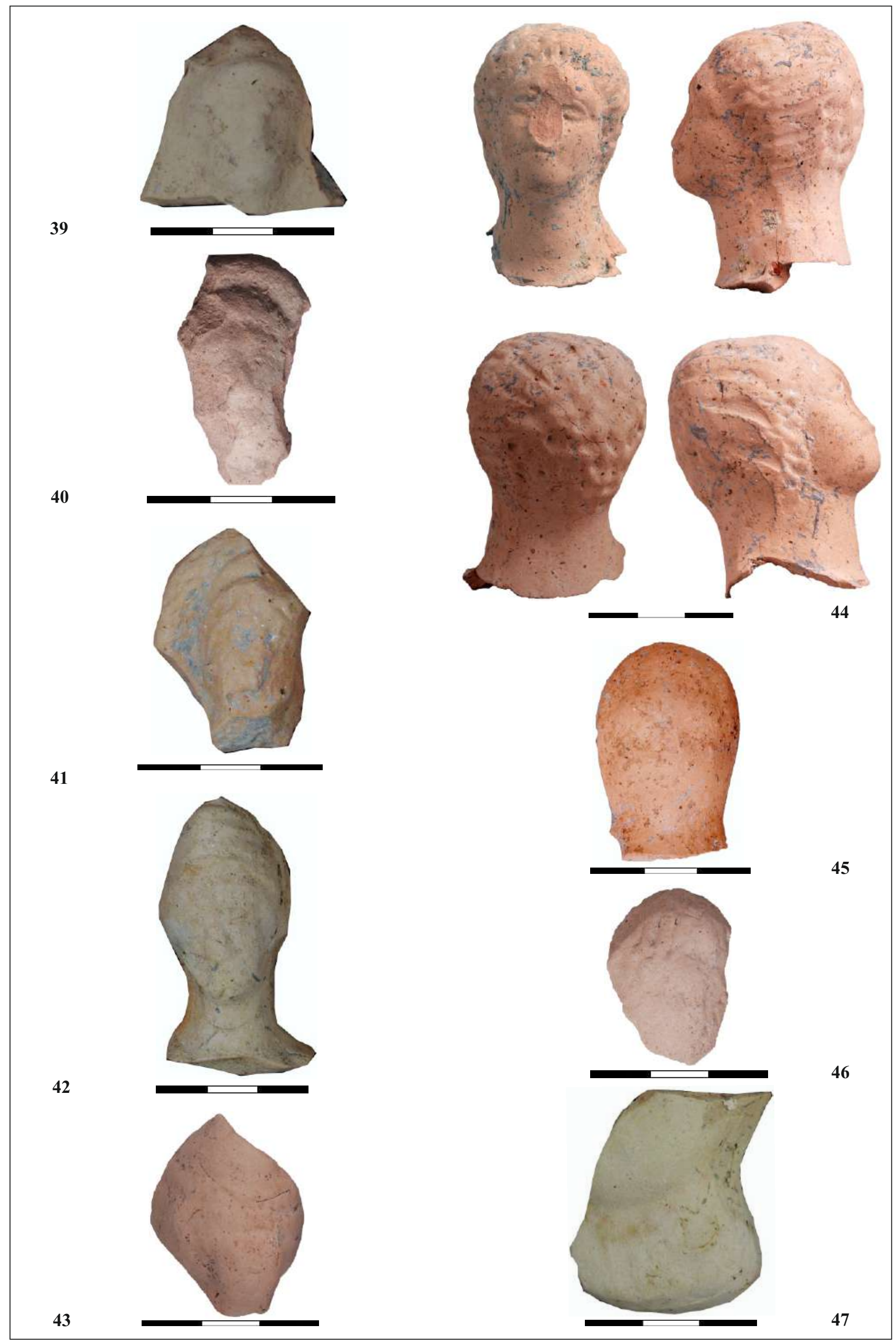

PI. VII 


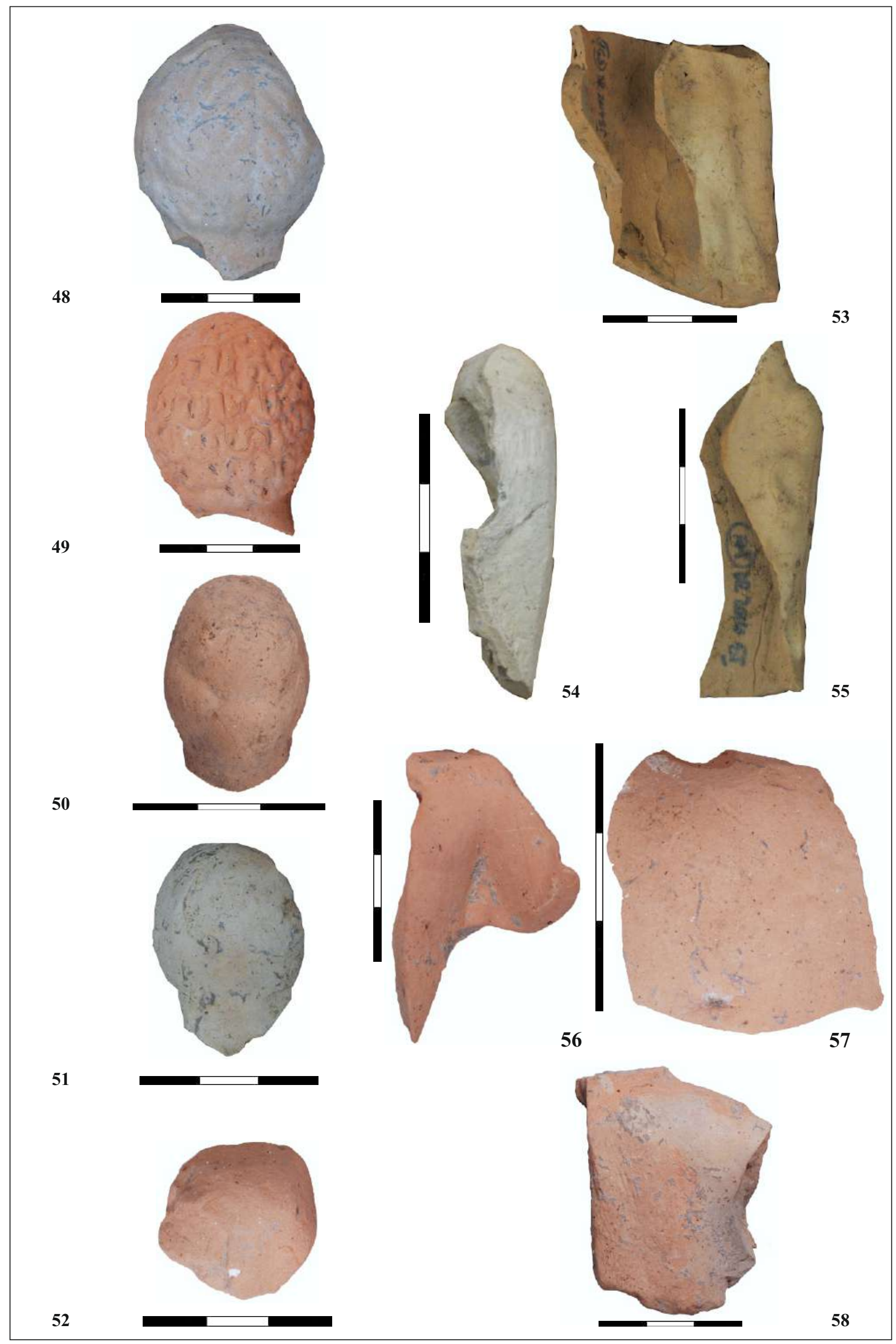

PI. VIII 


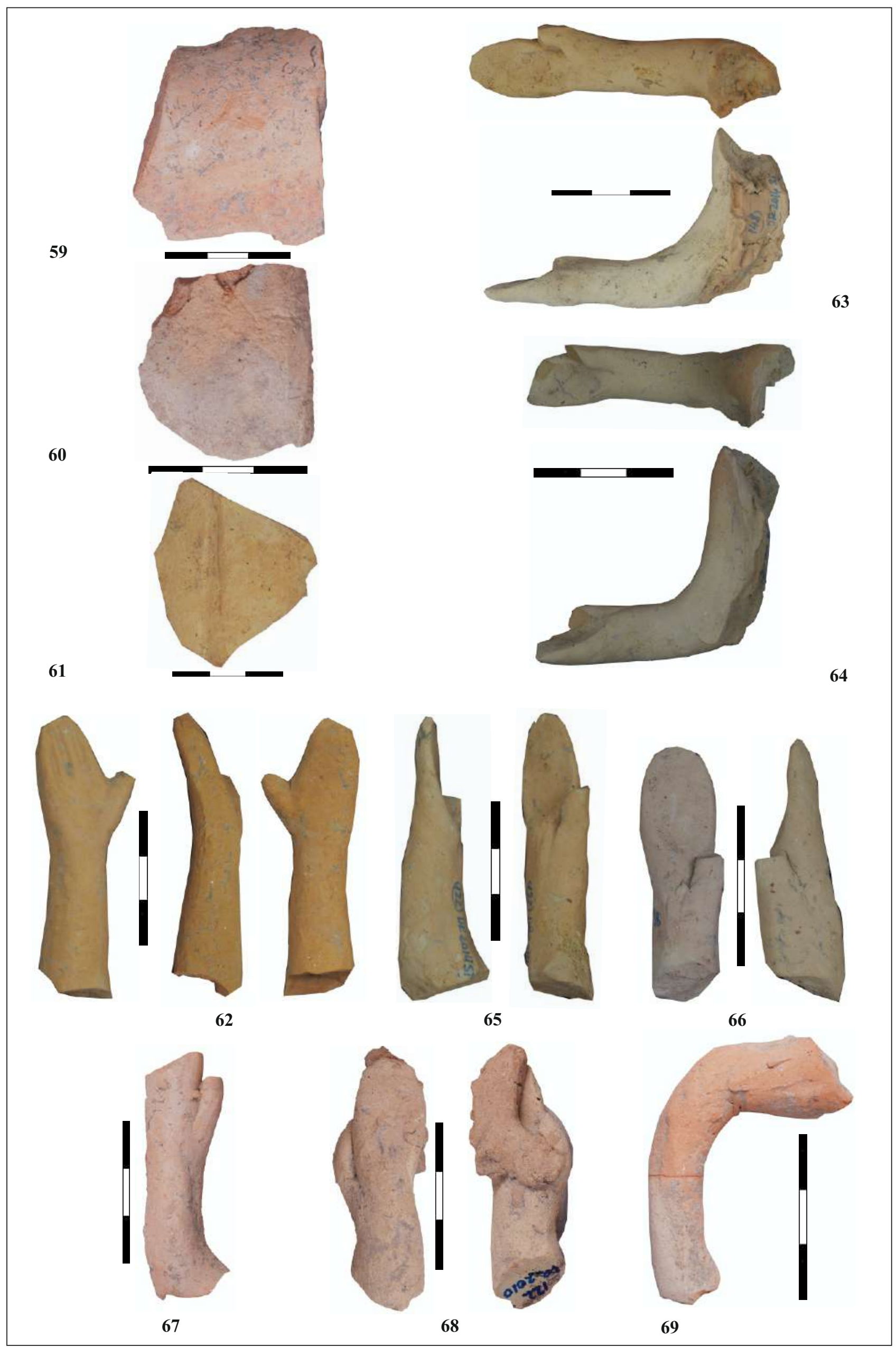

PI. IX 


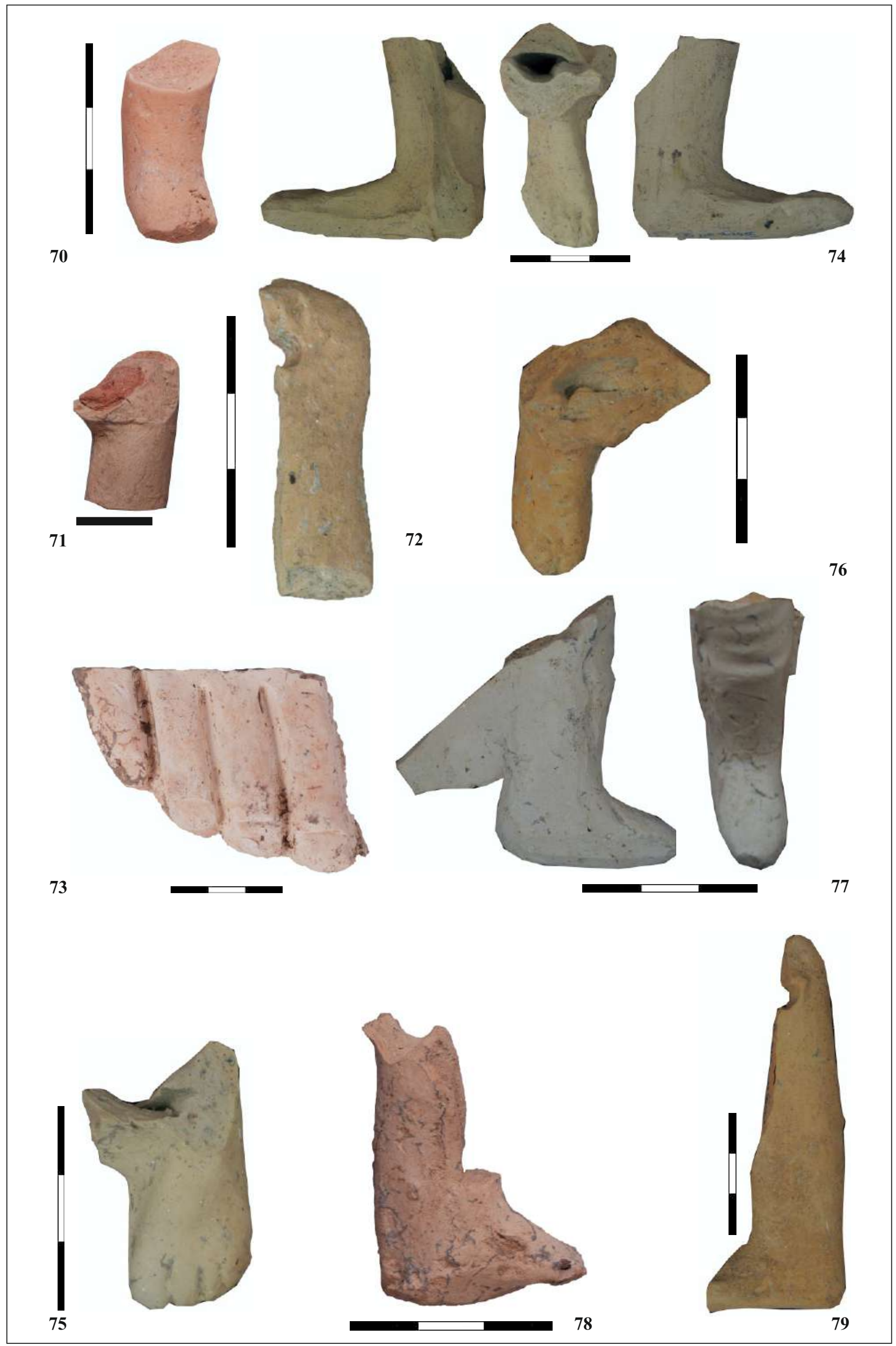

PI. X 